$$
\text { UNIVERSIDADE DE SÃO PAULO }
$$

INSTITUTO DE ASTRONOMIA, GEOFÍSICA E CIÊNCIAS ATMOSFÉRICAS PROGRAMA DE PÓS-GRADUAÇÃO EM METEOROLOGIA

LUCAS FERREIRA CORREA

\title{
Impactos do transporte de aerossóis do deserto do Saara sobre o balanço de radiação sobre o Atlântico tropical e a Amazônia
}

São Paulo 


\title{
Impactos do transporte de aerossóis do deserto do Saara sobre o balanço de radiação sobre o Atlântico tropical e a Amazônia
}

\author{
Versão Corrigida. \\ (O original encontra-se disponível na unidade).
}

Dissertação apresentada ao Instituto de Astronomia, Geofísica e Ciências Atmosféricas da Universidade de São Paulo para a obtenção do título de Mestre em Ciências.

Área de concentração: Meteorologia

Orientadora: Prof. Dra. Marcia Akemi Yamasoe

São Paulo

2020 


\section{AGRADECIMENTOS}

Agradecimento especial à minha orientadora, Prof. Dra. Marcia Akemi Yamasoe, pela orientação, paciência, apoio, conselhos e todo conhecimento transmitido.

A todos os professores do Departamento de Meteorologia, que contribuíram enormemente à minha formação.

Aos meus pais Ana Cristina e Carlos Magno, e à minha avó Mercídia (em memória), que foram e ainda são minhas bases e maior apoio de todos. Tudo é por eles e graças a eles.

Aos amigos que eu encontrei durante o mestrado, Humberto, Franciele, Marcos, Elen, Andressa, Erick, Paulo e todos os outros que me apoiaram, torceram por mim e são parte de boa parte das minhas melhores memórias desses anos.

Aos meus amigos e colegas do Laboratório de Radiação e Aerossóis Atmosféricos, pelo apoio e colaboração durante esses anos.

Aos meus amigos do time de flag football Politécnica Rats, onde eu encontrei uma família durante os anos de mestrado.

Aos meus amigos e familiares que, mesmo do Amapá e do Pará, nunca me deixaram esquecer que eu nunca estive sozinho mesmo nos momentos mais difíceis.

À Universidade de São Paulo, por me proporcionar uma experiência acadêmica e pessoal incrível durante o mestrado.

À CAPES pelo apoio financeiro. 


\section{RESUMO}

Todos os anos, centenas de milhões de toneladas de areia são transportadas do deserto do Saara para outras regiões. Para a Amazônia este fenômeno ganhou notoriedade devido à sua importância do ponto de vista bioquímico, uma vez que, com a areia, são transportadas grandes quantidades de minerais que enriquecem o solo da floresta. Entretanto, o transporte de aerossóis do deserto do Saara para a Amazônia também é importante no que tange ao balanço radiativo do planeta, uma vez que os aerossóis em suspensão na atmosfera interagem com a radiação, afetando o saldo de radiação, especialmente no espectro solar. Nas últimas décadas diversos estudos investigaram o fenômeno desde o aspecto estrutural das plumas de aerossol até o aspecto radiativo. Neste estudo busca-se contribuir para os conhecimentos sobre este tema, destacando a importância da região de origem do aerossol no deserto do Saara e como evolui o impacto radiativo das plumas desde que elas deixam o continente africano. Para isso, foram utilizados dados de fluxos radiativos medidos em satélites e dados de propriedades ópticas de aerossol medidos em superfície, além de simulações numéricas. Os resultados mostram que, além da depressão de Bodélé, outra região entre o norte de Mali, Mauritânia e o sul da Argélia, também é importante fonte de aerossóis transportados para a Amazônia. Observou-se também que, devido às diferenças nas propriedades ópticas, os aerossóis de cada uma das origens têm eficiências de forçamento radiativo diferentes, com uma eficiência maior pelos aerossóis originários de Bodélé, tendo a eficiência diária de forçamento radiativo de $-36 \pm 4 \mathrm{~W} /\left(\mathrm{m}^{2} \mathrm{~T}\right.$ dia $)$ na média dos meses calculados, contra $-31 \pm 4 \mathrm{~W} /\left(\mathrm{m}^{2} \mathrm{~T}\right.$ dia $)$ dos aerossóis do norte de Mali, diferença estatisticamente significativa ao nível de significância de 5\%. Com relação ao deslocamento das plumas, observou-se uma redução de até 10\% ( $3 \mathrm{~W} / \mathrm{m}^{2}$ T dia) na eficiência diária de forçamento radiativo desde que as plumas deixam o continente africano (primeira etapa do transporte) até a região intermediária entre os dois continentes (segunda etapa do transporte), com uma projeção de diminuição de pelo menos $40 \%$ na eficiência para as plumas que chegam à Amazônia (terceira etapa do transporte). O estudo contribui para o conhecimento sobre os impactos radiativos dos aerossóis do deserto do Saara, sobre o transporte em si, e abre espaço para 
discussões sobre a tradução dos impactos radiativos em impactos termodinâmicos e dinâmicos na atmosfera, que refletem no tempo e no clima.

Palavras-chave: Aerossóis, deserto do Saara, Amazônia, balanço de radiação, forçamento radiativo. 


\section{ABSTRACT}

Every year, hundreds of million tons of dust are transported from the Sahara desert to other regions. For the Amazon, this phenomenon gained notoriety mostly because of its importance on the biochemistry aspect, once that, together with the dust, a big quantity of minerals which fertilize the Amazon soil is transported. However, the transport of Saharan dust to the Amazon is also important in what regards to the radiative balance of the planet, once that the aerosols in suspension in the atmosphere interact with radiation, affecting the radiation budget, especially in the solar spectrum. In the last decades several studies investigated this phenomenon from the structure of the plumes to the radiative aspects. This study tries to expand the knowledge about this theme, highlighting the importance of the origin of the dust within the desert and how the radiative impact evolves since the plumes leave the African continent. For that, data from satellites and surface were analyzed, as well as numerical simulations were carried out. The results show that, besides the Bodélé Depression, another source lying between northern Mali, Mauritania and southern Algeria, is also an important source of the aerosols transported to the Amazon. It was also observed that, because of the differences on their optical properties, the aerosols from each source have different diurnal radiative forcing efficiency, with a higher efficiency of the aerosols from Bodélé, with a diurnal efficiency of $-36 \pm 4$ $\mathrm{W} /\left(\mathrm{m}^{2} \mathrm{~T}\right.$ day $)$ on the mean of the calculated months, against $-31 \pm 4 \mathrm{~W} /\left(\mathrm{m}^{2} \mathrm{~T}\right.$ day $)$ of the aerosols from northern Mali, a statistically significative difference a $5 \%$ significance level. Concerning to the evolution of the radiative impacts during the transport, it was observed a decrease as high as $10 \%\left(\sim 3 \mathrm{~W} / \mathrm{m}^{2} \mathrm{~T}\right.$ day) on the diurnal radiative forcing efficiency since the plumes left the continent (first stage of the transport) until an intermediate region between the two continents (second stage of the transport), with a projection of a decrease of at least $40 \%$ on the efficiency for the plumes that reach the Amazon (third stage of the transport). This study contributes to the knowledge about the radiative impacts of the Saharan dust transport, about the transport itself, and opens space for discussions about the translation of these impacts on the atmosphere thermodynamics and dynamics, which will reflect on weather and climate. 
Keywords: Aerosols, Sahara desert, Amazon, radiative balance, radiative forcing. 


\section{LISTA DE FIGURAS}

Figura 1: Forçamento Radiativo (colunas sólidas) e Eficiência de Forçamento Radiativo (colunas hachuradas) para diferentes constituintes. Adaptado de IPCC, 2013.

Figura 2: Localização da Depressão de Bodelé 5

Figura 3: $\mathrm{O}$ espectro eletromagnético. (Fonte: Adaptado de https://upload.wikimedia.org/wikipedia/commons/c/cf/EM_Spectrum_Properties_edit. svg Acesso em maio de 2020).

Figura 4: Regiões de maior intensidade de emissão de radiação pelo Sol e pela Terra (Fonte: disponível

em http://mtc-m21c.sid.inpe.br/col/sid.inpe.br/mtc-m21c/2019/09.10.11.42/doc/ANA\%20 CAROLINA\%20QUIQUETO.pdf. Acesso em abril de 2020).

Figura 5: Padrão de espalhamento de radiação ou representação gráfica da função de fase (radiação incidindo da esquerda para a direita) para diferentes parâmetros de tamanho (x) [Adaptado: notas de aulas Prof. Vanderlei Martins (2019) - São Paulo School of Atmospheric Science on Atmospheric Aerosols].

Figura 6: Geometria da incidência de radiação solar na atmosfera, na vertical (dz) e no caminho óptico (ds), com determinado ângulo zenital solar $\theta$ (Fonte: Silva (2012). Disponível em:

https://teses.usp.br/teses/disponiveis/14/14133/tde-14082013-132802/publico/Dissert aFINAL.pdf. Acesso em abril de 2020).

Figura 7: Área de estudo.

Figura 8: Localização dos sítios AERONET na África que tiveram dados utilizados neste estudo.

Figura 9: Distribuição de tamanho das partículas em 28/01/2016 no sítio AERONET de Cabo Verde. Evento de transporte de aerossóis não usado devido à grande presença de aerossóis da moda fina, possivelmente originários de queima de biomassa 
Figura 10: Glint solar no Golfo do México (imagem disponível em: http://spaceref.com/2019/02/. Acesso em abril de 2020).

Figura 11: Deslocamento longitudinal dos pontos observados em evento de transporte de 18 a 24 de janeiro de 2005.

Figura 12: Localização geográfica dos pontos sobre o oceano utilizados referentes aos 40 eventos utilizados neste estudo, destacando as três etapas de transporte 29

Figura 13: Distribuição da AOD média..................................... 40

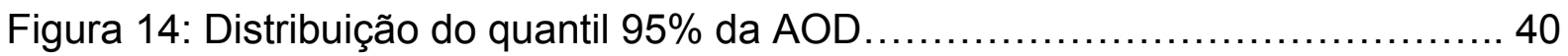

Figura 15: AOD média diária no sítio AERONET em Banizoumbou, no Níger.... 41

Figura 16: Origens das plumas de aerossol e estações AERONET utilizadas neste estudo. O marcador entre o norte de Mali e da Mauritânia representa uma posição aproximada de toda uma região de onde a areia se origina 44

Figura 17: AOD em 23 de Março de 2018, mostrando pluma de aerossóis originária do norte de Mali deixando o continente com núcleo (valores mais elevados) por volta de $15^{\circ}$ norte 45

Figura 18: AOD em 23 de Março de 2010, mostrando pluma de aerossóis originária de Bodelé. Apesar de espalhada até latitudes mais elevadas, deixa o continente com núcleo (valores mais elevados) por volta de $5^{\circ}$ norte.

Figura 19: Relevo africano. Fonte: IBGE. 46

Figura 20: Modelo de dispersão Hysplit indicando a região do norte de Mali como origem da massa de ar transportada para sobre Cabo Verde.

Figura 21: Imagem no espectro visível do oeste africano em 28/03/2017. Fonte: EOSDIS NASA 
Figura 22 - Velocidade do vento em superfície em 21/3/2010, mostrando velocidade do vento elevada na região de origem dos aerossóis (na depressão de Bodelé) 49

Figura 23: Velocidade do vento em superfície em 23/03/2018, evento de transporte com origem no norte de Mali. 50

Figura 24: Origem dos aerossóis nos 40 eventos utilizados neste estudo. 51

Figura 25: Origem da areia nos eventos em que as plumas chegaram até a Amazônia..... 52

Figura 26: Forçamento Radiativo Instantâneo Médio para o aerossol originário da região de Bodelé, estimado a partir das passagens do satélite Aqua 53

Figura 27: Forçamento Radiativo Instantâneo Médio para o aerossol originário da região de Bodelé, estimado a partir das passagens do satélite Terra 54

Figura 28: Forçamento Radiativo Instantâneo Médio para o aerossol originário da região do norte de Mali, estimado a partir das passagens do satélite Aqua..... 54

Figura 29: Forçamento Radiativo Instantâneo Médio para o aerossol originário da região do norte de Mali, estimado a partir das passagens do satélite Terra...... 55

Figura 30: Estrutura vertical da pluma de aerossóis num evento de transporte em 04/03/2014 (produzido com o Aerosol Mask). 56

Figura 31: Distribuição dos valores de $F(I w)$, que é resultado da divisão do FRA no espectro terrestre pelo FRA no espectro solar, no TOA, para um mesmo pixel, em eventos originários de Bodelé.

Figura 32: Distribuição dos valores de $F(\mathrm{Iw})$, que é resultado da divisão do $F R A$ no espectro terrestre pelo FRA no espectro solar, no TOA, para um mesmo pixel, em eventos originários de Mali. 58 
Figura 33: Relação AOD x FRA instantâneo no espectro solar no TOA na etapa 1, estimados pelo satélite Aqua. Letra b ou $\mathrm{m}$ após parâmetros estatísticos indica Bodelé ou Mali. 59

Figura 34: Relação AOD x FRA instantâneo no espectro solar no TOA na etapa 1, estimados pelo satélite Terra. Letra b ou m após parâmetros estatísticos indica Bodelé ou Mali. 60

Figura 35: Relação AOD x FRA instantâneo no espectro solar no TOA na etapa 2, estimados pelo satélite Aqua. Letra b ou m após parâmetros estatísticos indica Bodelé ou Mali. 60

Figura 36: Relação AOD x FRA instantâneo no espectro solar no TOA na etapa 2, estimados pelo satélite Terra. Letra b ou $\mathrm{m}$ após parâmetros estatísticos indica Bodelé ou Mali. 61

Figura 37: Relação AOD x FRA instantâneo no espectro solar no TOA na etapa 3, estimados pelo satélite Aqua. Letra b ou m após parâmetros estatísticos indica Bodelé ou Mali. 61

Figura 38: Relação AOD x FRA instantâneo no espectro solar no TOA na etapa 3, estimados pelo satélite Terra. Letra b ou $\mathrm{m}$ após parâmetros estatísticos indica Bodelé ou Mali.

Figura 39: Eficiência instantânea média de forçamento radiativo para aerossol originário de Bodelé, estimado a partir dos satélites Terra e Aqua.... 64

Figura 40: Eficiência instantânea média de forçamento radiativo para aerossol originário do norte de Mali, estimado a partir dos satélites Terra e Aqua. 64

Figura 41: Ângulo zenital médio do sol para as medições de cada satélite, em cada etapa, para cada origem dos aerossóis. 65

Figura 42: Relação AOD x FRA instantâneo no espectro solar no TOA sobre o continente - Aerossóis de Bodelé. 
Figura 43: Relação AOD x FRA instantâneo no espectro solar no TOA sobre o continente - Aerossóis de Mali.

Figura 44: Deslocamento dos aerossóis em evento de transporte de 13 a 21 de fevereiro de 2001. Sítio AERONET do Suriname e de Cabo Verde destacados em preto e vermelho, respectivamente. 69

Figura 45: Profundidade óptica de aerossol em evento de transporte de 13 a 21 de fevereiro de 2001. Sítio AERONET do Suriname e de Cabo Verde destacados em preto e vermelho, respectivamente.

Figura 46: Distribuição de tamanho das partículas em 13 de fevereiro de 2001, no sítio AERONET de Cabo Verde.

Figura 47: Distribuição de tamanho das partículas em 22 de fevereiro de 2001, no sítio AERONET do Suriname. Neste dia foi observada a chegada de pluma de aerossóis originária do deserto do Saara

Figura 48: Albedo simples das partículas em 13 de fevereiro de 2001 no sítio AERONET de Cabo Verde e em 22 de fevereiro de 2001 no sítio AERONET do Suriname 72

Figura 49: Melhor ajuste de curva simulada de $\frac{d(\text { albedo) }}{d(A O D)}$ em função do cosseno do ângulo zenital solar para a) a etapa 1 do transporte e b) a etapa 2 do transporte de aerossóis originários de Bodelé. 74

Figura 50: Melhor ajuste de curva simulada de $\frac{d(\text { albedo })}{d(A O D)}$ em função do cosseno do ângulo zenital solar para a) a etapa 1 do transporte e b) a etapa 2 do transporte de aerossóis originários do norte de Mali. 75

Figura 51: Melhor ajuste de curva simulada de $\frac{d(\text { albedo })}{d(A O D)}$ em função do cosseno do ângulo zenital solar para a etapa 2 do transporte de aerossóis originários da depressão de Bodelé comparado com observado na etapa 3 76 
Figura 52: Melhor ajuste de curva simulada de $\frac{d(\text { albedo })}{d(A O D)}$ em função do cosseno do ângulo zenital solar para a etapa 2 do transporte de aerossóis originários do norte de Mali comparado com observado na etapa 3

Figura 53: Eficiência diária de forçamento radiativo de janeiro a julho, para os aerossóis de Bodelé, nas duas etapas do transporte. 78

Figura 54: Eficiência diária de forçamento radiativo de janeiro a julho, para os aerossóis de Mali, nas duas etapas do transporte 79

Figura 55: Eficiência diária de forçamento radiativo para os aerossóis de Mali com diferentes coordenadas.

Figura 56: AOD média mensal para todos os dias de 2001 a 2018 na etapa 1 82

Figura 57: Forçamento radiativo médio diário de aerossóis de cada uma das origens de janeiro a julho, utilizando AOD média mensal para cada um dos meses em questão entre 2001 e 2018 83

Figura 58: AOD média de janeiro a julho na etapa 1 para os anos de 2001 a 2018. 84

Figura 59 - FRA médio diário para um cenário com apenas aerossóis de Bodelé para os meses de a) janeiro e fevereiro; b) março e abril; c) maio, junho e julho de 2001 a 2018

Figura 60 - Diferença do FRA médio diário de cada mês para todo o valor médio mensal de todo o período (apresentado na figura 57): cenário com aerossóis de Bodelé. a) janeiro e fevereiro; b) março e abril; c) maio, junho e julho de 2001 a 2018. 85

Figura 61 - FRA médio diário para um cenário com apenas aerossóis de Mali para os meses de a) janeiro e fevereiro; b) março e abril; c) maio, junho e julho de 2001 a 2018 86

Figura 62 - Diferença do FRA médio diário de cada mês para todo o valor médio mensal de todo o período (apresentado na figura 57): cenário com aerossóis de Mali. 
a) janeiro e fevereiro; b) março e abril; c) maio, junho e julho de 2001 a 2018. 86

Figura 63: Forçamento radiativo médio diário em dias com evento de transporte de aerossóis originários de Bodelé. 88

Figura 64: Forçamento radiativo médio diário em dias com evento de transporte de aerossóis originários de Mali. 88

Figura 65: Forçamento Radiativo de Aerossol médio diário em 24 de março de 2010. Escala em $\mathrm{W} / \mathrm{m}^{2}$ dia. Regiões no extremo de $-20 \mathrm{~W} / \mathrm{m}^{2}$ dia indicam a inexistência de aerossóis do deserto do Saara. 90

Figura 66: Forçamento Radiativo de Aerossol médio diário em 27 de março de 2010. Escala em $\mathrm{W} / \mathrm{m}^{2}$ dia. Regiões no extremo de $-10 \mathrm{~W} / \mathrm{m}^{2}$ dia indicam a inexistência de aerossóis do deserto do Saara. 91

Figura 67: Forçamento Radiativo de Aerossol médio diário em 30 de março de 2010. Escala em $\mathrm{W} / \mathrm{m}^{2}$ dia. Regiões no extremo de $-10 \mathrm{~W} / \mathrm{m}^{2}$ dia indicam a inexistência de aerossóis do deserto do Saara. 91

Figura 68: Forçamento Radiativo de Aerossol médio diário em 01 de maio de 2012. Escala em W/m² dia. Regiões no extremo de $-20 \mathrm{~W} / \mathrm{m}^{2}$ dia indicam a inexistência de aerossóis do deserto do Saara. 92

Figura 69: Forçamento Radiativo de Aerossol médio diário em 04 de maio de 2012. Escala em W/m² dia. Regiões no extremo de $-12 \mathrm{~W} / \mathrm{m}^{2}$ dia indicam a inexistência de aerossóis do deserto do Saara. 93 


\section{ÍNDICE}

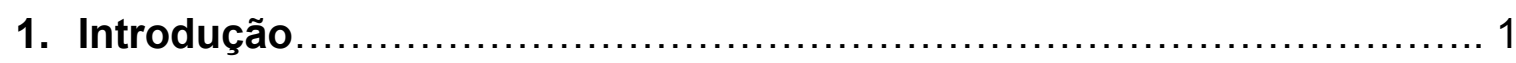

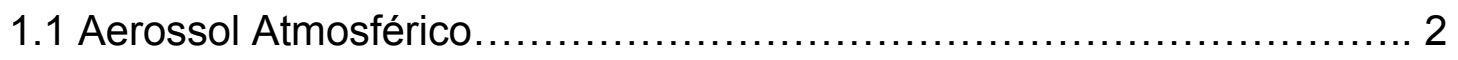

1.2 Transporte de aerossóis do deserto do Saara ............................... 3

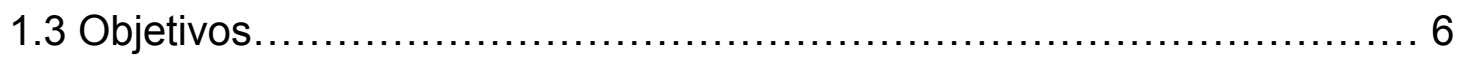

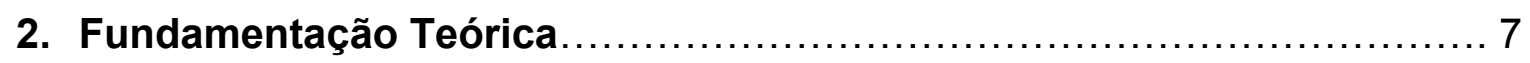

2.1 Radiação na atmosfera e balanço radiativo.................................. 8

2.2 Interação aerossol-radiação................................................ 10

2.3 Propriedades ópticas dos aerossóis do Saara.............................. 11

2.4 Lei de Beer-Lambert-Bouguer........................................... 13

2.5 Visão geral dos aspectos meteorológicos associados ao transporte de aerossóis do Saara.................................................................... 14

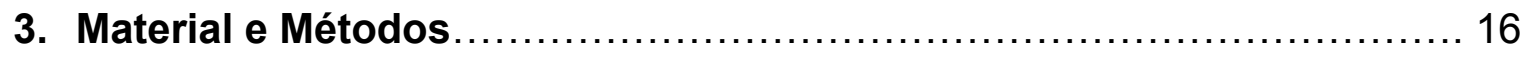

3.1 Região e período de estudo............................................ 17

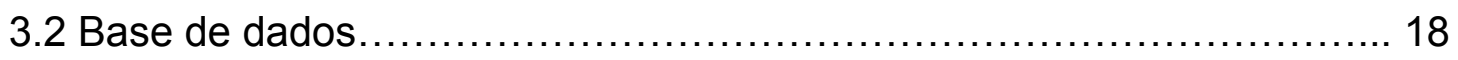

3.2.1 Fluxos radiativos............................................... 18

3.2.2 Profundidade óptica de aerossol............................... 19

3.2.3 Propriedades ópticas do aerossol................................. 20

3.3 Código de transferência radiativa LibRadtran............................... 21

3.4 Identificação dos eventos de transporte de aerossol........................ 21

3.5 Identificação da origem das plumas de aerossol............................. 23

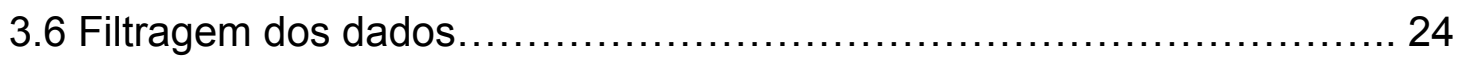

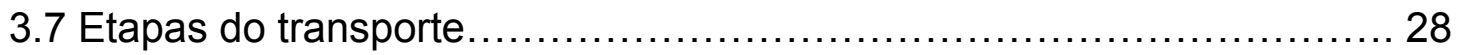

3.8 Forçamento Radiativo de Aerossol (FRA) e Eficiência Radiativa de

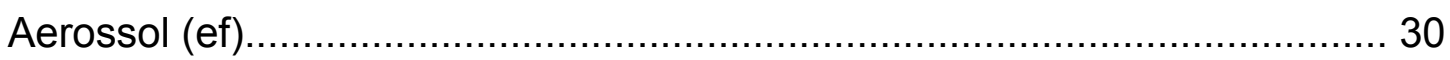

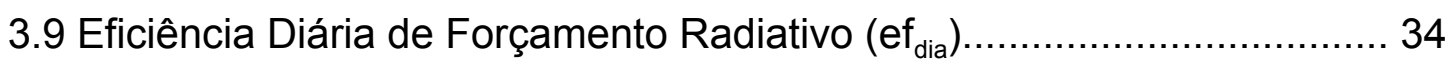

3.9.1 Procedimentos de cálculo da curva de albedo observada........ 34

3.9.2 Procedimento de ajuste da curva de albedo simulada............ 36

3.9.3 Integração da eficiência diária de forçamento radiativo............ 36

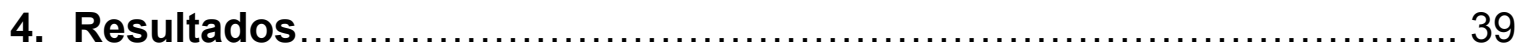

4.1 Eventos de transporte de aerossóis, origens e padrões associados...... 40 
4.2 Forçamento Radiativo e Eficiência de Forçamento Radiativo Instantâneos

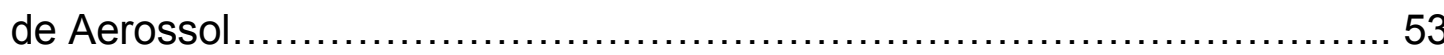

4.3 Areia do deserto do Saara na Amazônia...................................6 66

4.4 Eficiência Diária de Forçamento Radiativo............................... 73

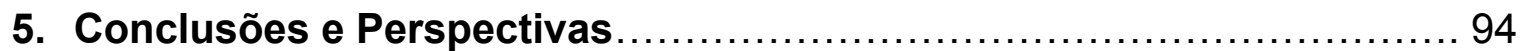

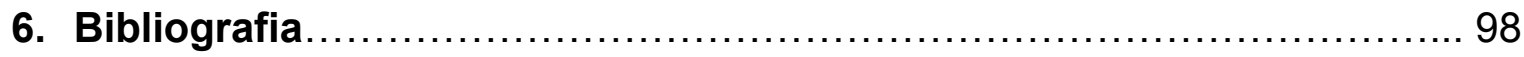


Capítulo 1: Introdução 


\subsection{Aerossol atmosférico}

Aerossóis são partículas líquidas ou sólidas (com exceção dos hidrometeoros) em suspensão na atmosfera com tamanhos que variam de alguns nanômetros a dezenas de micrômetros. Eles desempenham um papel importante no sistema climático devido à sua participação nos processos físicos da atmosfera. Esses processos podem ser divididos nos efeitos diretos e indiretos sobre o balanço de radiação. Os efeitos diretos se referem a processos de absorção, espalhamento e emissão de radiação pelos aerossóis, enquanto que os efeitos indiretos se referem a processos de nucleação de nuvens, tendo aerossóis como núcleos de condensação (Haywood \& Boucher, 2000). Os impactos do efeito indireto se estendem até mesmo a variações no balanço hídrico (Lohmann \& Feichter, 2004)

Devido à reconhecida importância dos aerossóis para o tempo e clima, estes são importante objeto de estudo de diferentes segmentos. Destaque para os relatórios do IPCC, que desde a década de 1990 já salientavam os aerossóis como, além de um importante ator para as mudanças do clima, uma das principais fontes de erros e incertezas nos modelos climáticos. Myhre et al. (2013) ainda classificaram o nível de confiança do efeito total dos aerossóis para o balanço de radiação como médio, numa escala que vai de muito baixo a muito alto.

Para medir o efeito dos aerossóis no balanço de radiação, as medidas mais comumente utilizadas são o Forçamento Radiativo e a Eficiência de Forçamento Radiativo. No primeiro relatório do IPCC (IPCC, 1990), o Forçamento Radiativo é definido como a medida da mudança no fluxo radiativo devido à mudança num constituinte atmosférico. No oitavo capítulo do quinto relatório de avaliação do IPCC (Myhre et al., 2014), a Eficiência de Forçamento Radiativo é incluída, e no contexto de aerossóis, é definida como o Forçamento Radiativo por unidade de Profundidade Óptica de Aerossol (AOD), grandezas definidas no capítulo 2. A figura 1 mostra as estimativas destas medidas para diversos constituintes na escala global, retirada do quinto relatório do IPCC. 
Forçamento radiativo do clima entre 1750 e 2011 Agente forçante

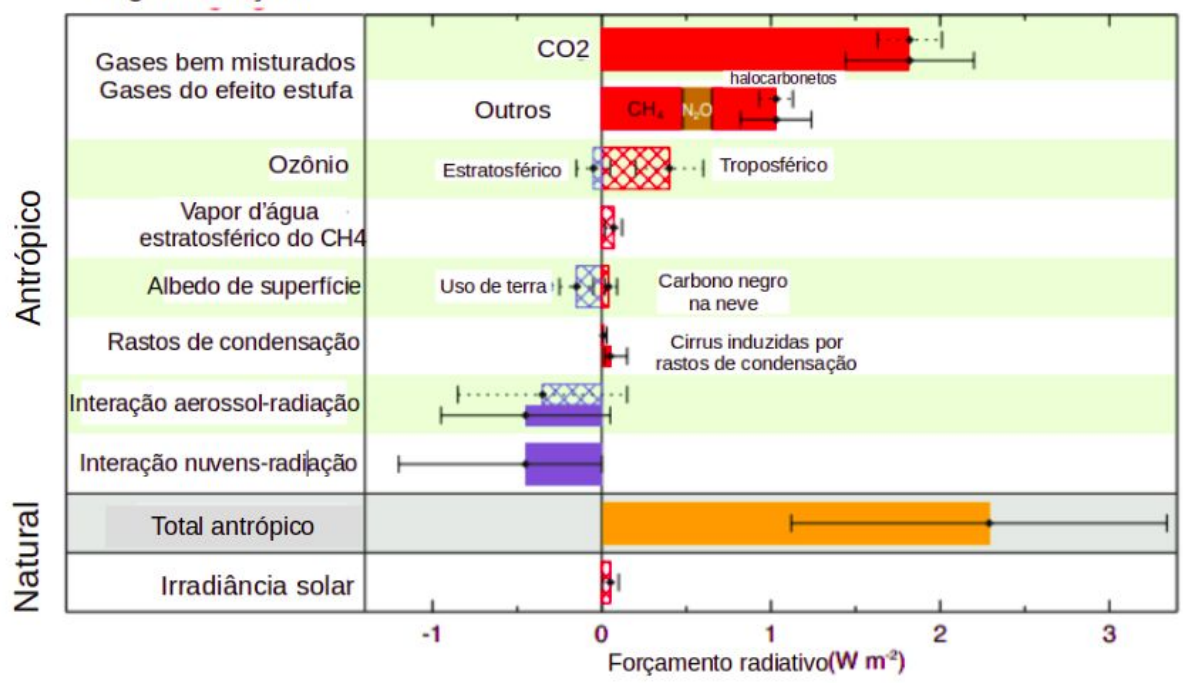

Figura 1 - Forçamento Radiativo (colunas sólidas) e Eficiência de Forçamento Radiativo (colunas hachuradas) para diferentes constituintes. Adaptado de IPCC, 2013.

As grandes incertezas ainda presentes, associadas aos processos de interação aerossol-radiação são uma das motivações ao desenvolvimento do presente trabalho.

\subsection{Transporte de aerossóis do Deserto do Saara}

O deserto do Saara é o terceiro maior deserto do mundo, atrás da Antártida e do Ártico, sendo o maior deserto em regiões não polares. Sua área de 9400000 km² está disposta por 11 países. Sua dimensão continental e a atuação dos ventos em baixos níveis fazem do deserto uma significativa fonte de aerossóis para a atmosfera.

O transporte de aerossóis do Saara tem sido objeto de estudos há mais de 4 décadas. Próspero \& Carlson (1972) fizeram a primeira caracterização da estrutura das plumas de aerossol que eram transportadas para o Oceano Atlântico. Num trabalho mais recente, Liu et al. (2012) identificaram que no verão do hemisfério norte as plumas se estruturam de $2 \mathrm{~km}$ de altitude até acima de $5 \mathrm{~km}$, enquanto que nas outras estações o limite superior não costuma passar dos $4 \mathrm{~km}$ de altitude.

Os aerossóis transportados do Saara têm como destino três principais regiões: o Mediterrâneo e Europa (Moulin et al., 1998), o Oriente Médio (Yaalon \& 
Ganor, 1979) e o Caribe e Amazônia através do Oceano Atlântico (Swap et al., 1992). Este último é o objeto de estudo deste trabalho, que tem foco no período em que essas plumas se deslocam para a Amazônia, num caminho que dura em média 7 dias (Ott et al., 1991).

Segundo estimativas de Kaufman et al. (2005), cerca de 240 milhões de toneladas de aerossóis do deserto do Saara são transportados para o Oceano Atlântico todos os anos, das quais cerca de 140 milhões de toneladas são depositadas no próprio oceano (pela ação da gravidade, correntes descendentes de vento ou chuva), 50 milhões de toneladas são depositadas no Caribe e outras 50 milhões de toneladas são depositadas na Amazônia. Essa quantidade massiva de aerossóis leva consigo minerais que são importantes do ponto de vista bioquímico, pois fertilizam o solo da floresta amazônica (Bristow et al., 2010). O principal deles é o fósforo, cuja importância e associação com fontes de aerossóis do Saara foi investigada por Okin et al. (2004). Além do impacto bioquímico, o impacto climático é um importante aspecto a ser investigado, seja nos efeitos diretos ou indiretos dos aerossóis. Diversos estudos já investigaram estes impactos (Li et al., 2004; Kedia et al., 2018; Tiwari et al. 2019; Singh et al., 2016), e o presente estudo pretende contribuir para a compreensão deste fenômeno.

No que diz respeito à origem, a principal fonte de aerossóis do deserto do Saara transportados para a Amazônia é uma região conhecida como Depressão de Bodelé (Figura 2), um antigo lago no norte do Chade, que concentra a maior parte das emissões de areia transportadas até a Amazônia (Koren et al., 2006). Washington \& Todd (2005) catalogaram um jato de baixos níveis na região, conhecido como Jato de Baixos Níveis de Bodelé (Bodelé low level jet), que é a principal forçante na origem do transporte. Entretanto, na escala sinótica e global, outros fatores contribuem para o desenvolvimento e o destino do transporte, como as ondas de leste (Jones et al., 2003), e até mesmo o posicionamento da Zona de Convergência Intertropical (ZCIT), que através dos ventos alísios controla o destino das plumas mais ao sul, levando-as para a Amazônia, ou mais ao norte, para o Caribe. 


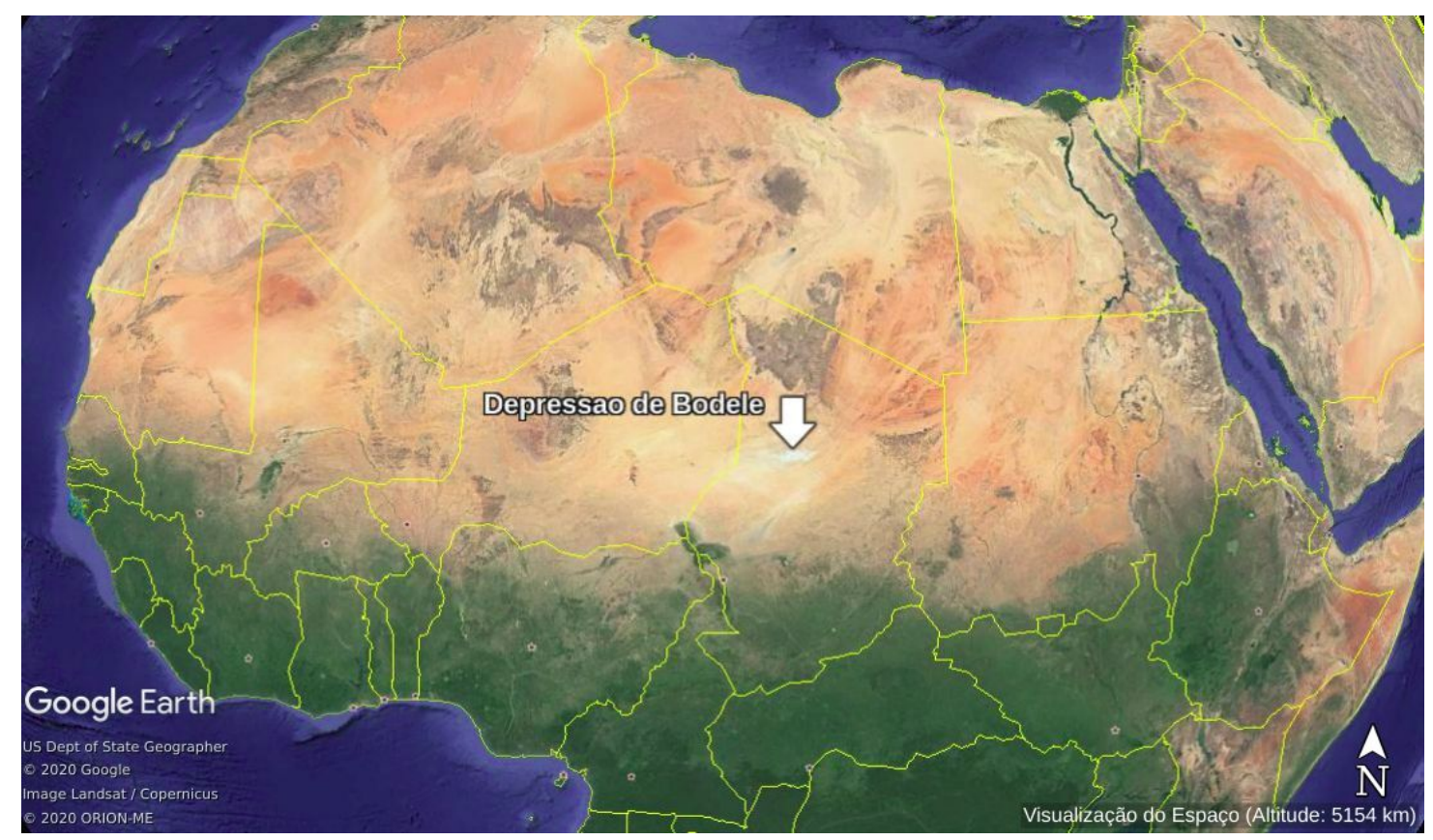

Figura 2 - Localização da Depressão de Bodelé

Além da depressão de Bodelé, diversos estudos apontam outra importante fonte de aerossóis no oeste Saariano, entre Mali, Mauritânia e Argélia (Chiapello et al., 1997; Middleton \& Goudie, 2001; Gläser et al., 2015). Alguns deles, como Gläser et al. (2015), indicando essa região como mais importante que a depressão de Bodelé no contexto do transporte intercontinental de aerossóis. Dentre os principais sistemas atmosféricos atuantes na origem do transporte de aerossóis dessa região no período deste estudo, destacam-se o posicionamento da alta subtropical (Chiapello et al., 1997) e a ocorrência de ventos Harmatão (Oluleye \& Jimoh, 2018).

Liu et al. (2012) mostraram que o período de maior emissão de areia para a atmosfera, no deserto do Saara, está compreendido entre os meses de junho a agosto, seguidos dos meses de março a maio. Segundo o mesmo trabalho, o período de menor atividade como um todo está compreendido entre os meses de dezembro e fevereiro, entretanto, aspectos locais de cada região do deserto resultam em diferentes regimes locais de emissão de areia. Entre dezembro e fevereiro também ocorrem os máximos de queimadas na região subsaariana (Duncan et al., 2003); nos outros meses do ano as emissões por queima de biomassa ficam próximas a 0 . Essa informação é importante, uma vez que aerossóis derivados de queima de biomassa têm propriedades ópticas diferentes dos 
aerossóis originários do deserto, e consequentemente interagem com a radiação de forma diferente.

\subsection{Objetivos}

O objetivo principal deste trabalho foi estudar o impacto no balanço de radiação (espectro solar e espectro terrestre) do transporte de aerossóis do deserto do Saara para o Atlântico tropical e a Amazônia. O objetivo principal foi explorado de forma mais específica através da análise dos principais eventos de transporte de aerossóis do deserto do Saara no período de 2001 a 2018 sobre o oceano Atlântico e a Amazônia, destacando os meses em que a Zona de Convergência Intertropical está deslocada mais ao sul, e utilizando dados observacionais de satélites e simulações com código de transferência radiativa. A ênfase maior foi dada ao forçamento radiativo e eficiência de forçamento radiativo no topo da atmosfera (TOA) no espectro solar, a fim de gerar estimativas de eficiência diária de forçamento radiativo para todas as etapas do transporte da África até a América do Sul baseadas em dados observacionais, e assim identificar possíveis alterações no impacto radiativo das plumas entre o começo e o fim do deslocamento.

Objetivou-se também identificar possíveis diferenças na eficiência de forçamento radiativo devido à ocorrência de diferentes origens do aerossol transportado, além de observar a evolução do impacto radiativo com o deslocamento a oeste das plumas de aerossol. 
Capítulo 2: Fundamentação Teórica 


\subsection{Radiação na Atmosfera e Balanço Radiativo}

Radiação é definida pela emissão ou propagação de energia por meio de ondas eletromagnéticas ou fótons (Yamasoe \& Corrêa, 2016). Qualquer corpo com temperatura acima do zero absoluto $\left(\begin{array}{ll}0 & \mathrm{~K}\end{array}\right)$ emite radiação. As ondas eletromagnéticas podem ter maior ou menor energia, e assim ter maior ou menor comprimento de onda. Daí surge o conceito de espectro eletromagnético, que é a classificação dessas ondas de acordo com sua frequência ou comprimento de onda. A figura 3 ilustra várias regiões do espectro eletromagnético.

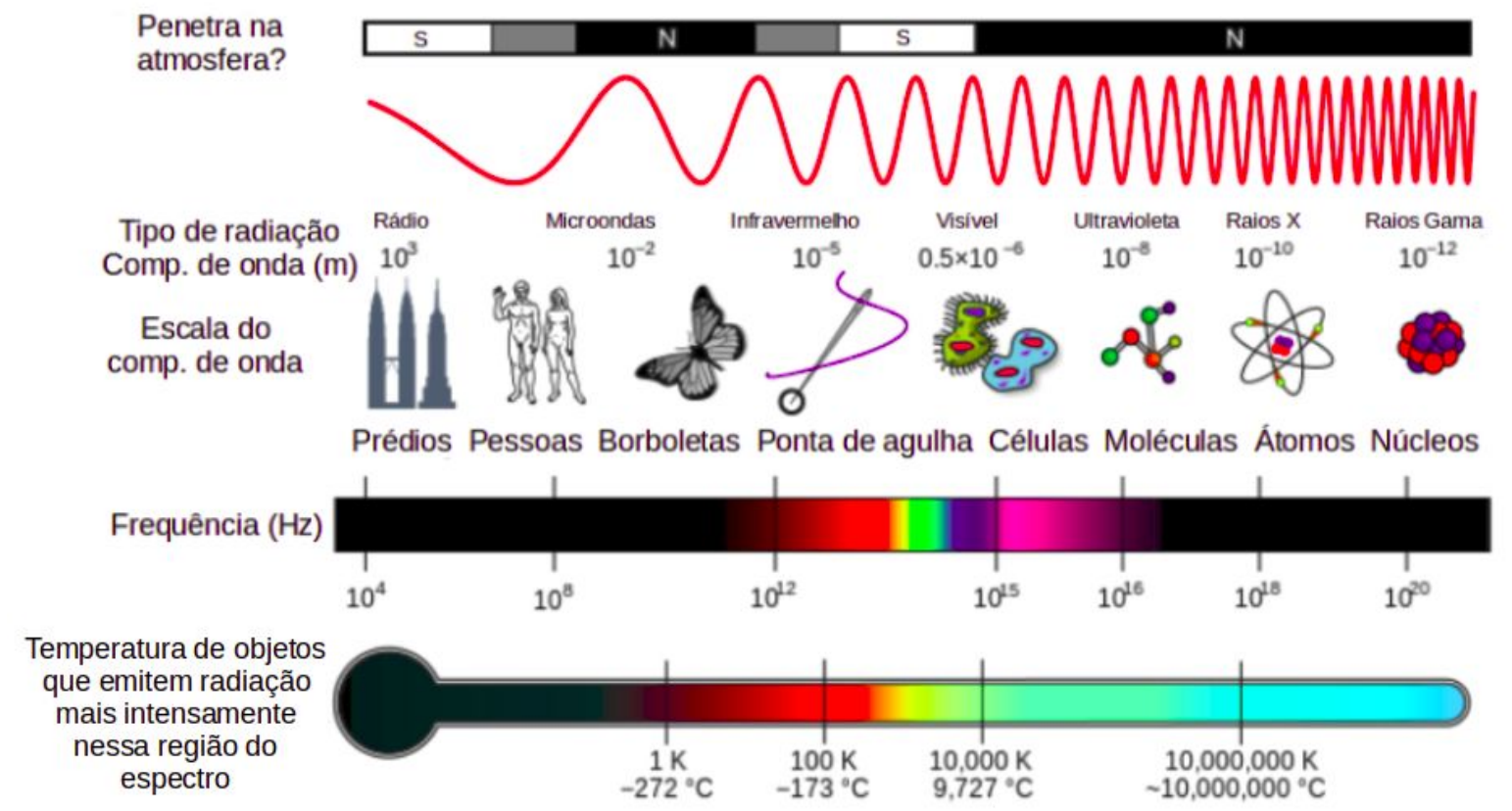

Figura 3 - O espectro eletromagnético. (Fonte: Adaptado de https://upload.wikimedia.org/wikipedia/commons/c/cf/EM_Spectrum_Properties_edit.svg Acesso em maio de 2020)

No que se refere à radiação disponível na atmosfera, existem duas principais fontes: o sol, e o sistema Terra-atmosfera. O sol e o planeta Terra têm temperaturas bastante diferentes, logo, emitem radiação com seus máximos de emissão em diferentes regiões do espectro eletromagnético. A figura 4 ilustra essas regiões. 


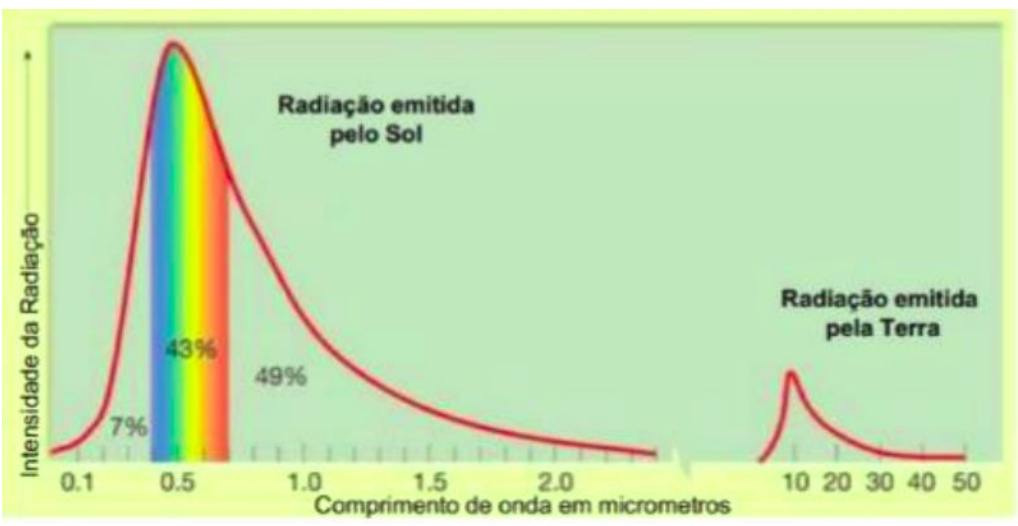

Figura 4 - Regiões de maior intensidade de emissão de radiação pelo Sol e pela Terra (Fonte: disponível em http://mtc-m21c.sid.inpe.br/col/sid.inpe.br/mtc-m21c/2019/09.10.11.42/doc/ANA\%20CAROLINA\%20Q UIQUETO.pdf. Acesso em abril de 2020).

Os fluxos radiativos solar e terrestre compõem o balanço radiativo do planeta, que é o saldo de radiação no sistema, que é ilustrado pela equação (1), segundo Liou (2002).

$$
F=(1-\alpha) Q-\mathrm{F}_{\text {ir }}
$$

Onde $\mathrm{F}$ é o saldo do fluxo radiativo planetário, $\mathrm{Q}$ é o fluxo radiativo solar descendente no TOA, $\alpha$ é o albedo planetário e $F_{\text {ir }}$ é a radiação de onda longa emergente no TOA. Apesar da simplicidade da equação (1), nela são representados diversos processos na atmosfera. O albedo planetário depende, além do albedo de superfície, da presença de componentes que interajam com a radiação solar, como nuvens e aerossóis, e dos processos de absorção e espalhamento de radiação por esses componentes. A radiação de onda longa emergente depende da emissão de radiação pelo sistema Terra-atmosfera em direção ao TOA, bem como dos processos de absorção e espalhamento entre a fonte emissora e o TOA.

Em grande escala de tempo, o saldo dos fluxos radiativos de onda curta (solar) e de onda longa (terrestre) é nulo, ou seja, a quantidade de radiação que entra no sistema Terra-atmosfera é igual à que sai. Segundo o princípio de conservação de energia, se o saldo radiativo é nulo, não há troca de calor e a energia interna se mantém constante, ou seja, a temperatura se mantém constante. Entretanto a alteração de componentes na atmosfera e em superfície pode alterar o 
balanço de energia, resultando num aquecimento ou resfriamento de pequenas regiões, ou até mesmo do planeta como um todo.

\subsection{Interação aerossol-radiação}

Os aerossóis atmosféricos são importantes para os processos radiativos na atmosfera, especialmente no espectro do visível, infravermelho próximo e ultravioleta próximo (Horvarth, 1993). Diversos fatores afetam o processo de interação entre aerossol e radiação e consequente reflexo no balanço de radiação, dentre eles estão a concentração do aerossol na atmosfera, capacidade de absorção, e características de espalhamento da radiação pelo aerossol. Em relação à concentração de um dado aerossol na atmosfera, a medida amplamente utilizada é a profundidade óptica de aerossol (do inglês Aerosol Optical Depth ou AOD), descrita pela equação (2), seguindo a definição por Yamasoe \& Corrêa (2016).

$$
\tau\left(\lambda, z^{\prime}\right)=\int_{\infty}^{z^{\prime}} \beta\left(\lambda, z^{\prime \prime}\right) d z^{\prime \prime}
$$

Onde $\tau\left(\lambda, z^{\prime}\right)$ é a profundidade óptica de aerossol num determinado comprimento de onda $\lambda$ e uma determinada altura $z^{\prime}$ da atmosfera, e $\beta\left(\lambda, z^{\prime \prime}\right)$ é o coeficiente linear de atenuação, que é dado por:

$$
\beta\left(\lambda, z^{\prime \prime}\right)=\sigma\left(\lambda, z^{\prime \prime}\right) N\left(z^{\prime \prime}\right)
$$

Em que $\sigma\left(\lambda, z^{\prime \prime}\right)$ é a seção de choque eficaz de atenuação $\left(\mathrm{m}^{2}\right)$ para um dado comprimento de onda $\lambda$ e dada altura z" da atmosfera, e $N\left(z^{\prime \prime}\right)$ é a concentração numérica de partículas $\left(\mathrm{m}^{-3}\right)$ nessa mesma altura z" da atmosfera. Valores típicos de AOD estão entre 0 e 5.

Em relação à capacidade de absorção de radiação pelos aerossóis, a medida geralmente utilizada é o albedo simples. O albedo simples é um coeficiente que indica a fração da radiação atenuada por espalhamento, e é dado pela equação (4), como definido por Liou (2002):

$$
\omega\left(\lambda, z^{\prime}\right)=\frac{\beta e\left(\lambda, z^{\prime}\right)}{\beta\left(\lambda, z^{\prime}\right)}
$$

Onde $\omega\left(\lambda, z^{\prime}\right)$ é o albedo simples em um determinado comprimento de onda e caminho óptico, $\beta e\left(\lambda, z^{\prime}\right)$ é o coeficiente linear de espalhamento, $\beta\left(\lambda, z^{\prime}\right)$ é o coeficiente linear de atenuação total. Um albedo simples igual a 1 indica a 
inexistência de absorção, enquanto que um albedo simples de 0 indica a inexistência de espalhamento.

O espalhamento de radiação se refere à mudança de direção da propagação das ondas eletromagnéticas sem mudança nos comprimentos de onda. O tamanho da partícula é um fator determinante ao processo de espalhamento. Uma medida utilizada para tratar do tamanho da partícula é o parâmetro de tamanho (x), que é definido por Liou (2002) como:

$$
x=2 \pi r / \lambda
$$

Onde x é o parâmetro de tamanho, e r é o raio da partícula em $\mu m$, com o comprimento de onda $\lambda$ na mesma unidade.

Há alguns modelos adotados para descrever o espalhamento de radiação por partículas, de acordo com o parâmetro de tamanho. Para valores de $\mathrm{x}$ em torno de 1, que geralmente é o caso dos aerossóis, o modelo mais amplamente utilizado é o da Teoria Mie (Liou, 2002). A Teoria Mie é usada para descrever o espalhamento e também a absorção por partículas esféricas homogêneas. Entretanto, na natureza, as partículas não são esferas perfeitas, então esse modelo representa uma aproximação do que é de fato observado. Segundo Liou (2002) as eficiências de extinção (que, neste trabalho, trata do mesmo processo que atenuação), espalhamento e de absorção na teoria Mie são definidos, respectivamente, por:

$$
\begin{aligned}
& \mathrm{Q}_{\text {ext }}=\frac{2}{x^{2}} \sum_{n=1}^{\infty}(2 n+1) \operatorname{Re}\left(\mathrm{a}_{\mathrm{n}}+\mathrm{b}_{\mathrm{n}}\right) \\
& \mathrm{Q}_{\mathrm{esp}}=\frac{2}{x^{2}} \sum_{n=1}^{\infty}(2 n+1)\left(\left|\mathrm{a}_{\mathrm{n}}\right|^{2}+\left|\mathrm{b}_{\mathrm{n}}\right|^{2}\right) \\
& \mathrm{Q}_{\mathrm{abs}}=\mathrm{Q}_{\mathrm{ext}}-\mathrm{Q}_{\mathrm{esp}}
\end{aligned}
$$

O padrão de espalhamento de radiação, ou representação gráfica da função de fase, está diretamente ligado ao tamanho da partícula. A figura 5, na seção 2.3, ilustra o padrão de espalhamento para diferentes valores do parâmetro de tamanho.

\subsection{Propriedades ópticas dos aerossóis do Saara}

Segundo a categorização amplamente utilizada, os aerossóis originados no deserto do Saara são da moda grossa (diâmetro > 2,5 $\mu \mathrm{m}$, ou $\mathrm{PM}_{10}$ ). Quando deixam o continente africano, é observado que a maior concentração é de partículas 
com diâmetro $5 \mu \mathrm{m}$. Devido ao seu tamanho, no entanto, boa parte dessas partículas são depositadas na fase inicial do transporte, e as partículas menores têm maior possibilidade de estarem presentes até a América do Sul.

Devido ao seu tamanho, adota-se a teoria Mie para descrever como as partículas interagem com a radiação, apesar de elas não serem esféricas, como espera-se por este modelo. Outra consequência do tamanho das partículas é o elevado parâmetro de tamanho, que fica aproximadamente entre 20 e 40 para comprimentos de onda no visível. Consequentemente, o parâmetro de assimetria é elevado e o espalhamento de radiação no espectro visível por essas partículas é preferencialmente frontal. O parâmetro de assimetria é um fator que representa o grau de assimetria da função de fase, para o qual o valor igual a 0 representa um espalhamento simétrico, e o valor de 1 representa um espalhamento completamente frontal (Yamasoe \& Corrêa, 2016). Dubovik et al. (2002) encontraram valores do parâmetro de assimetria para esse tipo de aerossol em torno de 0,72 no espectro visível, reforçando o espalhamento preferencialmente frontal. A figura 5 ilustra o padrão de espalhamento para diferentes parâmetros de tamanho.

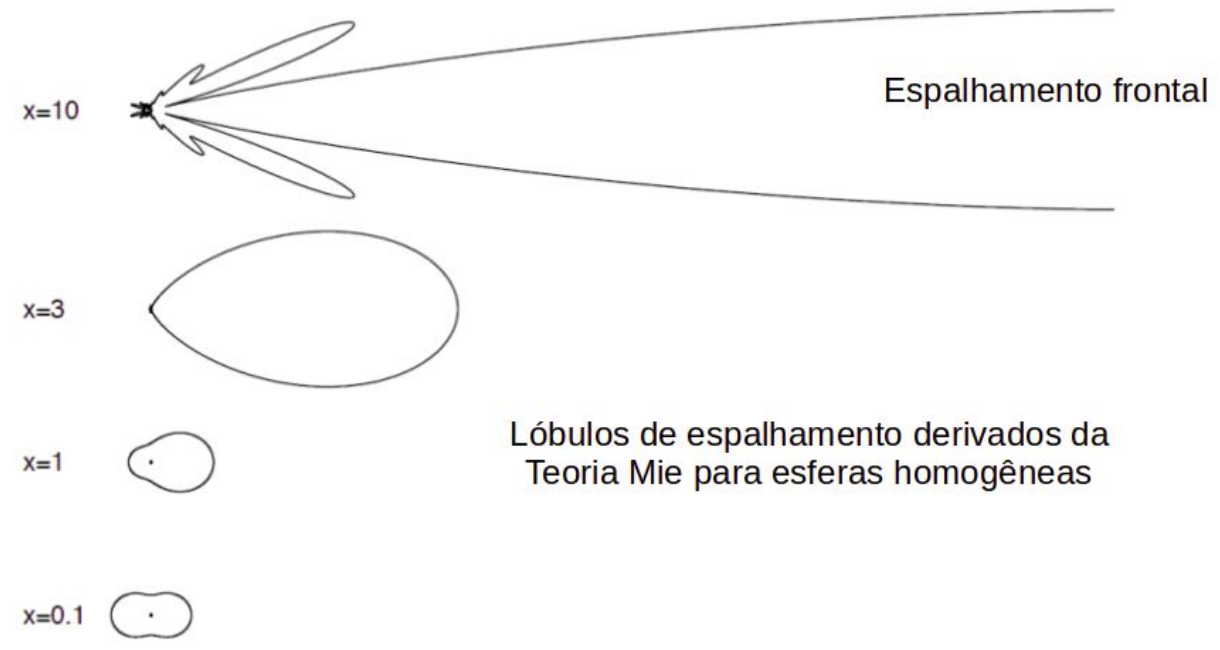

Figura 5 - Padrão de espalhamento de radiação ou representação gráfica da função de fase (radiação incidindo da esquerda para a direita) para diferentes parâmetros de tamanho (x) [Adaptado: notas de aulas Prof. Vanderlei Martins (2019) - São Paulo School of Atmospheric Science on Atmospheric Aerosols]. 
No que diz respeito à absorção de radiação, os aerossóis do Saara têm elevado albedo simples, logo, absorvem pouca radiação. Dubovik et al. (2002) avaliaram as propriedades ópticas de diversos tipos de aerossóis, e para aerossóis do deserto do Saara encontraram valores de albedo simples de 0,93 a 0,98 no espectro do visível, com esse valor aumentando para 0,99 no infravermelho próximo. Este padrão de aumento do albedo simples diretamente proporcional ao aumento do comprimento de onda é característico para esse tipo de aerossol.

\subsection{Lei de Beer-Lambert-Bouguer}

Também conhecida como lei de atenuação exponencial, a lei de Beer descreve a atenuação da radiação devido aos processos de absorção e espalhamento ao atravessar um meio. Sua forma é:

$$
L\left(s_{2}, \Omega\right)=L\left(s_{1}, \Omega\right) \exp \left[-\delta\left(, s_{1}, s_{2}\right)\right]
$$

Onde $L$ é a radiância espectral, $\Omega$ é uma determinada orientação de propagação, $s_{1}$ e $s_{2}$ são duas posições do caminho óptico (inicial e final, respectivamente), e $\delta$ é a espessura óptica do meio ao longo do caminho óptico. A espessura óptica difere da profundidade óptica no fato de que ela é integrada no caminho óptico (ds) independente da orientação, enquanto que a profundidade óptica é integrada na vertical (dz), como mostrado na figura:

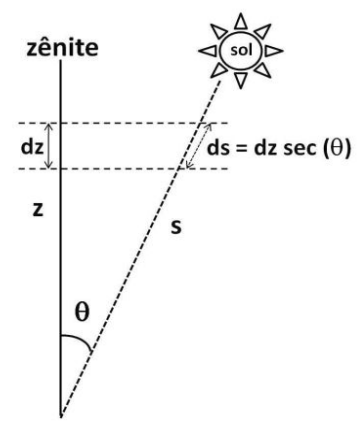

Figura 6 - Geometria da incidência de radiação solar na atmosfera, na vertical (dz) e no caminho óptico (ds), com determinado ângulo zenital solar $\theta$ (Fonte: Silva (2012). Disponível em: https://teses.usp.br/teses/disponiveis/14/14133/tde-14082013-132802/publico/DissertaFINAL.pdf. Acesso em abril de 2020).

São quatro os processos que ocorrem durante a interação da radiação com um determinado volume de matéria. São eles: (1) absorção, (2) emissão, (3) 
remoção por espalhamento e (4) adição por espalhamento (Yamasoe \& Corrêa, 2016). Quando juntamos todos esses processos numa só equação, temos a Equação de Transferência Radiativa (ETR). A ETR é a base para todo tipo de estudo de interação da radiação com a atmosfera. Ela é deduzida separadamente para cada componente do balanço de radiação (i.e. radiância espectral solar descendente, radiância espectral terrestre ascendente, etc). Neste trabalho a ETR não foi explicitamente deduzida ou resolvida, mas são utilizadas simulações com código de transferência radiativa e produtos de satélite, e em ambos a ETR é fundamental.

\subsection{Visão geral dos aspectos meteorológicos associados ao transporte de aerossóis do Saara}

O período de interesse deste estudo vai de dezembro a maio, correspondendo aos meses de inverno e primavera no hemisfério norte. Neste período do ano a Zona de Convergência Intertropical está posicionada mais ao sul, o que favorece o transporte das plumas de aerossol do deserto do Saara para a América do Sul.

Como já mencionado, são duas as principais fontes de aerossóis transportados do Saara para o Atlântico: a depressão de Bodelé, no norte do Chade, e uma região no oeste saariano, que compreende Mali, Mauritânia e Argélia. Em relação à depressão de Bodelé, o principal sistema atmosférico responsável pelo levantamento de areia na região é o Jato de Baixos Níveis de Bodelé, que é um sistema de ventos de nordeste, com máximos em 925 hPa (Washington \& Todd, 2005). Este sistema atmosférico é mais intenso no inverno boreal e está fortemente ligado à intensificação de um sistema de alta pressão sobre a Líbia (Washington \& Todd, 2005). No que diz respeito à região no oeste saariano, destacam-se dois sistemas atmosféricos no período de estudo: a alta subtropical, de outubro a abril (Chiapello et. al, 1997), e os ventos Harmatão, de novembro a março (Oluleye \& Jimoh, 2018). Segundo Chiapello et al. (1997) a configuração que mais favorece o levantamento de areia no oeste do Saara é o posicionamento da alta dos Açores a sudoeste da península Ibérica, sobre o oceano Atlântico. Quanto à ocorrência de ventos Harmatão, Oluleye \& Jimoh (2018) indicam, dentre outros fatores, anomalias 
negativas de temperatura de superfície do mar sobre o oceano Atlântico como um fator determinante à intensificação do transporte de aerossóis daquela região. Ambas as regiões sofrem pouca influência antrópica, logo a erosão e levantamento de aerossóis em ambas está diretamente ligado a fenômenos naturais (Middleton \& Goudie, 2001). 
Capítulo 3: Material e Métodos 


\subsection{Região e período do estudo}

A região de estudo é a faixa entre a África e a América do Sul pela qual as plumas de aerossol são transportadas entre os dois continentes. A região aproximada está destacada na figura 7, e vai da costa da África, passando pelo oceano Atlântico Tropical, até a Amazônia. O polígono destaca a região aproximada através da qual as plumas de aerossol são transportadas. A base de dados utilizada contém observações entre as longitudes de $65^{\circ} \mathrm{W}$ e $0^{\circ}$, e latitudes $5^{\circ} \mathrm{S}$ e $35^{\circ} \mathrm{N}$.

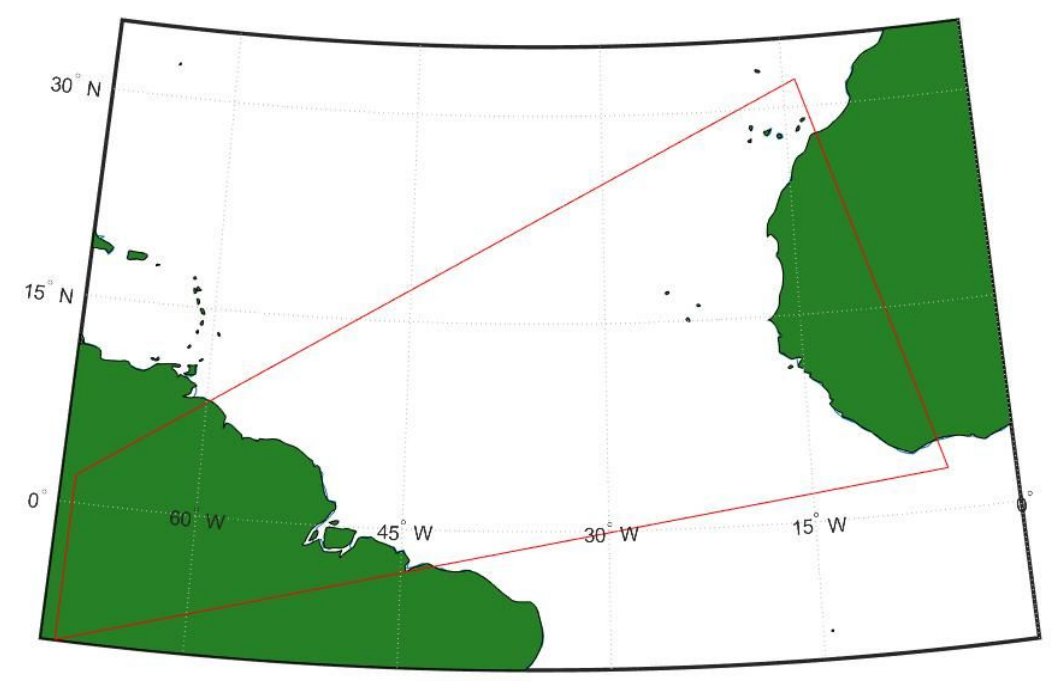

Figura 7 - Área de estudo.

Apesar de ocorrer levantamento e transporte de aerossóis do deserto do Saara para o oceano Atlântico durante basicamente todo o ano, este estudo deu ênfase aos meses em que esse transporte se desloca mais ao sul, devido ao posicionamento mais ao sul da Zona de Convergência Intertropical (ZCIT). Sendo assim, neste estudo foram utilizados dados de eventos ocorridos entre os meses de dezembro e maio, de 2001 a 2018. Algumas análises, entretanto, são feitas também para junho e julho, com a intenção possibilitar comparação com resultados de Li et al. (2004). Nestes casos, assumiu-se que as propriedades ópticas dos aerossóis de cada origem emitidos entre junho e julho, e consequentes processos de interação com a radiação, não diferem do que é observado nos outros meses. Porém, todos os aspectos associados à geometria solar destes meses foi considerada. Através da 
filtragem dos dados (ver seção 3.6) tentou-se minimizar qualquer efeito de mistura com outros tipos de aerossóis.

\subsection{Base de dados}

\subsubsection{Fluxos Radiativos}

Para a análise dos fluxos radiativos, foram utilizados dados do Cloud and Earth's Radiant Energy Budget (CERES). O Ceres é um projeto da National Aeronautics and Space Administration ou simplesmente NASA, que tem instrumentos de medição de fluxos radiativos em alguns satélites (NASA, 2020). Neste estudo foram utilizados dados do instrumento CERES a bordo dos satélites Terra e Aqua. Ambos são satélites de órbita polar heliossíncrona, com período de 99 minutos.

Os instrumentos CERES medem radiâncias em três regiões espectrais: no espectro solar, de 0,3 a $5 \mu \mathrm{m}$; na janela atmosférica, de 8 a $12 \mu \mathrm{m}$; e no espectro total, de 0,3 a $100 \mu \mathrm{m}$ (Smith et al., 2011). As radiâncias são convertidas em irradiâncias com a utilização de Modelos de Distribuição Angular (ADMs ou Angular Distribution Models), que dependem de diversas condições de superfície e atmosfera (Su et al., 2015). Os fluxos radiativos no espectro terrestre são calculados pela diferença entre os fluxos no espectro solar e o espectro total.

Para análise detalhada dos fluxos radiativos foi utilizado o produto CERES SSF-Level2 (Su et al., 2015), que tem uma resolução de 20 km x 20 km, e a latência instantânea, da passagem do satélite. As incertezas desse produto no TOA em regiões tropicais e céu claro é de $\sim 2,2 \%$ no espectro solar e de $\sim 1,1 \%$ no espectro terrestre. Como material de apoio, foram utilizados também o produto CERES_EBAF-Surface-Ed2.8 (Kato et al., 2013), de resolução espacial de $1^{\circ} \times 1^{\circ} \mathrm{e}$ latência mensal, e os produtos CERES-SSF1deg-Ed4A (Smith et al., 2011) e CERES-SYN1deg-Ed4A (Rutan et al.,2015), de resolução espacial de $1^{\circ} \times 1^{\circ} \mathrm{e}$ latência diária. O produto CERES_EBAF trata da climatologia fluxos radiativos, e os outros trazem informações diárias destes fluxos, e como material de apoio, foram utilizados para comparar com os resultados observados do CERES SSF-Level2, na escala diária e mensal, além de permitirem uma visualização das plumas, que apesar de ter pior resolução, é mais ampla. 
Os produtos do CERES disponibilizam informações dos fluxos radiativos no TOA (observado) e em superfície (modelado). A precisão e a validação dos modelos de superfície são descritos em (Kratz et al., 2010). Neste estudo, também são calculados os fluxos radiativos na camada referente à atmosfera, através da diferença entre os saldos em superfície e no TOA, onde: saldo atm = -saldo sfc saldo TOA. Os fluxos radiativos no espectro solar em superfície, na atmosfera, e os fluxos radiativos no espectro terrestre são analisados principalmente de forma qualitativa, com alguns aspectos quantitativos. O maior destaque, com análise quantitativa mais detalhada, é dado aos fluxos de radiação solar no TOA, por este ser resultado de dados observacionais (e não de modelos, como em superfície), e por, no espectro solar, o efeito da interação entre o tipo de aerossóis em questão e a radiação ser mais claro e ter valores significativamente mais elevados do que no espectro terrestre, como será mostrado mais à frente.

\subsubsection{Profundidade Óptica de Aerossol}

Os dados de profundidade óptica de aerossol utilizados neste estudo são originários do Moderate Resolution Imaging Spectroradiometer (MODIS). O MODIS é um instrumento a bordo dos satélites Terra e Aqua, já citados na seção anterior, que tem 36 bandas que vão de $0,41 \mu \mathrm{m}$ a $14,5 \mu \mathrm{m}$ (Xiong \& Barnes, 2006). Na identificação dos eventos de transporte de aerossóis foi utilizado o produto MOD04_3K (Levy et al., 2013), que tem resolução de $3 \mathrm{~km}$, e utiliza o método Dark Target (Kaufman \& Sendra, 1988) para estimar a AOD. Há de se destacar que o método Dark Target não é eficiente sobre superfícies com albedo muito elevado, como por exemplo o deserto do Saara. Entretanto, as plumas são acompanhadas desde que deixam a costa africana, logo, o método Dark Target não é um problema.

O produto CERES SSF-Level2 descrito na seção anterior traz também um produto de AOD derivado também do MOD04, da coleção 5.1. Esse valor de AOD é utilizado juntamente com os fluxos radiativos neste estudo. A incerteza associada a esse produto é de 0,03 + 5\% AOD sobre o oceano (Remer et al., 2008) e de 0,05+ $15 \%$ AOD sobre o continente (Levy et al., 2010). Todos os produtos de AOD utilizados referem à AOD no comprimento de onda de $550 \mathrm{~nm}$. 
Para visualização das plumas também foi utilizado o produto Lidar Aerosol Mask Product (Winker et al., 2010) do Lidar do CALIPSO (Cloud-Aerosol Lidar and Infrared Pathfinder). Através deste produto é possível identificar a estrutura vertical das plumas, o tipo de aerossol e a presença de nuvens.

\subsubsection{Propriedades Ópticas do Aerossol}

As informações de propriedades ópticas de aerossol são originárias do Aerosol Robotic Network, AERONET (Holben et al., 1998). A acurácia deste produto é descrita por Dubovik et al. (2000). Da AERONET foram utilizadas as estimativas de albedo simples, distribuição de tamanho e índice de refração, além da profundidade óptica de aerossol, que foi utilizada como informação de apoio para identificar a origem das plumas de aerossol.

Foram utilizados dados de 5 sítios AERONET: Cabo Verde $\left(16,733^{\circ} \mathrm{N}\right.$, $\left.22,935^{\circ} \mathrm{W}\right)$, Dakar, no Senegal $\left(14,394^{\circ} \mathrm{N}, 16,959^{\circ} \mathrm{W}\right)$, IER_Cinzana, no Mali $\left(13,278^{\circ} \mathrm{N}, 5,934^{\circ} \mathrm{W}\right)$, Banizoumbou, no Níger $\left(13,547^{\circ} \mathrm{N}, 2,665^{\circ} \mathrm{E}\right)$ e Zinder_Airport, no Níger $\left(13,777^{\circ} \mathrm{N}, 8.990^{\circ} \mathrm{E}\right)$. Os sítios foram escolhidos por estarem no caminho das plumas de aerossol, e por terem uma ampla cobertura temporal. A figura 8 mostra a localização dos 5 sítios.

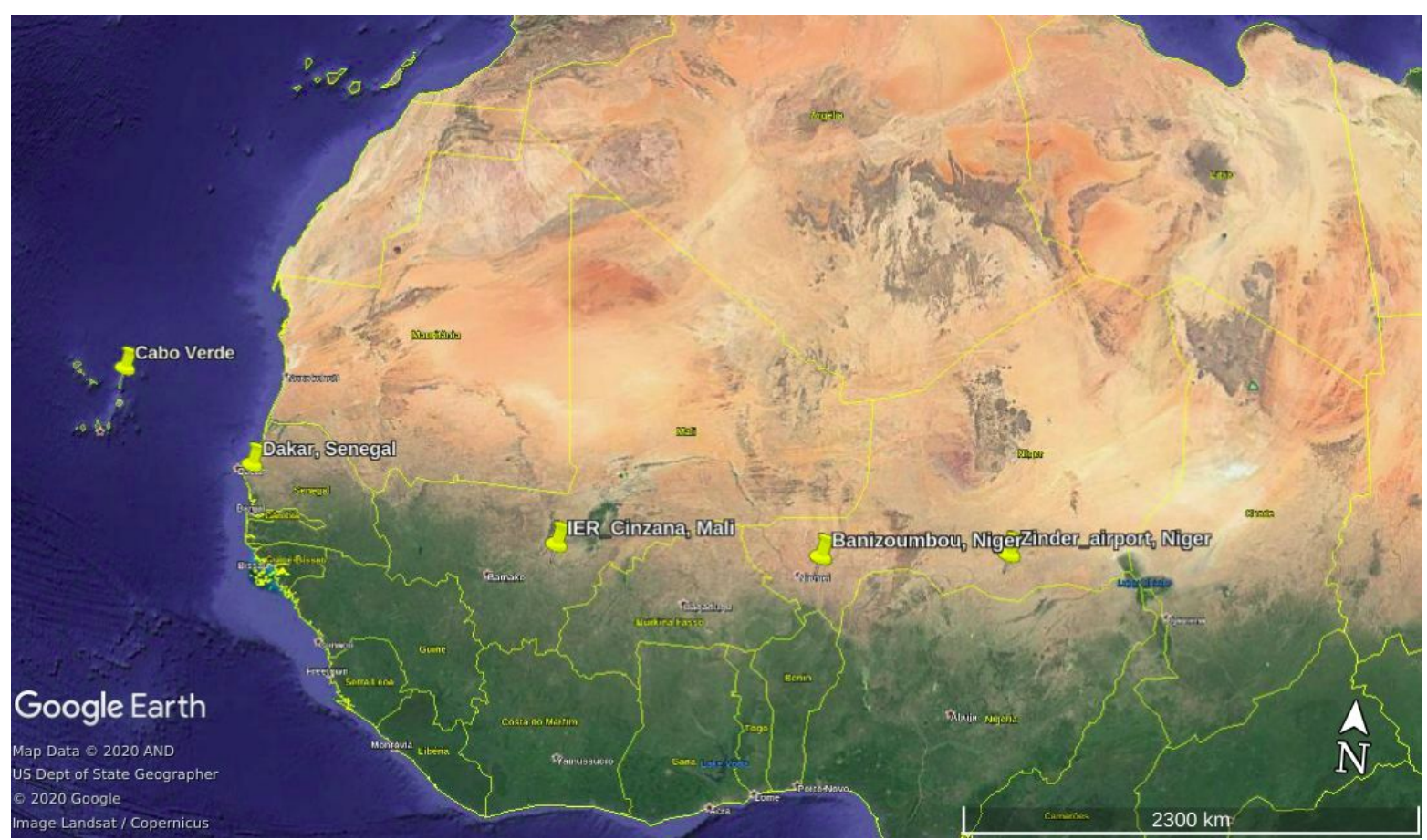

Figura 8 - Localização dos sítios AERONET que tiveram dados utilizados neste estudo. 


\subsection{Código de Transferência Radiativa LibRadtran}

O LibRadtran é um código de transferência radiativa desenvolvido em conjunto por diversos pesquisadores (Mayer \& Kylling, 2005). A principal ferramenta de transferência radiativa do código é o uvspec, dentro da qual há mais de 10 códigos de resolução da equação de transferência radiativa. Neste estudo foi utilizado o código DISORT (Stamnes et al., 1988), que é capaz de solucionar a ETR para uma atmosfera plano-paralela não homogênea.

As simulações do LibRadtran são utilizadas em dois momentos neste trabalho. Inicialmente são utilizadas para simular as cenas "limpas", sem a presença de aerossóis. Depois de identificar todos os pixels com presença de aerossóis a serem utilizados na análise do forçamento radiativo no espectro solar, no TOA, a geometria do sol de cada ponto foi utilizada como input para simular o fluxo radiativo no TOA na ausência de aerossóis, com $A O D=0,05$. O valor de 0,05 foi escolhido, ao invés de 0 , por, na atmosfera, a total inexistência de aerossóis num perfil atmosférico ser unusual.

Num segundo momento o código foi utilizado para simular curvas de d(albedo)/d(aod) [ver seção 3.9], para possibilitar o cálculo da eficiência de forçamento radiativo diária. Esse segundo caso envolve o cálculo das propriedades ópticas de aerossol, que foi feito com o código Mie (Wiscombe, 1980), também presente na biblioteca do LibRadtran, utilizando como entrada informações de distribuição de tamanho e índices de refração da AERONET. Em ambos os casos foi utilizada uma atmosfera tropical padrão e a geometria pseudo esférica, parâmetros de entrada também disponíveis na própria biblioteca do LibRadtran. $O$ albedo simples original da AERONET foi utilizado para comparar o observado em diferentes localizações, mas não foi utilizado nesta simulação.

\subsection{Identificação dos eventos de transporte de aerossol}

Para identificação dos eventos de transporte de aerossol associados à pluma do Saara foi utilizado o produto de AOD MOD04_3K, do instrumento MODIS a bordo do satélite Terra. Foram identificadas todas as passagens do satélite Terra na faixa entre as cidades de Dakar, no Senegal $\left(14,67^{\circ} \mathrm{N}, 17,43^{\circ} \mathrm{W}\right)$, e São Filipe, em Cabo 
Verde $\left(14,9^{\circ} \mathrm{N}, 24,5^{\circ} \mathrm{W}\right)$. Essa faixa tem aproximadamente $7^{\circ}$ de latitude e foi escolhida por nela ser possível observar as plumas de aerossóis que foram transportadas além da costa da África, que são o fenômeno de maior interesse deste estudo. A escolha desta faixa pode ter favorecido a identificação de eventos que tiveram origem na África ocidental, mais próximos da faixa em questão do que a depressão de Bodelé. Através dessa metodologia foi possível encontrar um total de 6717 observações, com pelo menos uma observação por dia, entre janeiro de 2001 e dezembro de 2018.

Para selecionar os eventos de transporte mais significativos dentre as 6717 observações, foram calculadas 11 variáveis para cada uma das observações/passagens do satélite. São elas: Número de pixels (npix), número de pixels válidos (nval), Número de pixels com AOD entre 0 e 1 (n0), número de pixels com AOD entre 1 e 2 (n1), número de pixels com AOD entre 2 e 3 (n2), número de pixels com AOD entre 3 e 4 (n3), número de pixels com AOD acima de 4 (n4), média da AOD dos pixels válidos (mean), quantil $5 \%$ da AOD dos pixels válidos (q05), quantil $50 \%$ da AOD dos pixels válidos (q50) e quantil 95\% da AOD dos pixels válidos (q95). As variáveis $n 1, n 2, n 3$ e n4 foram classificadas como variáveis de dimensão, pois estão diretamente ligadas à área das plumas. As variáveis q95 e mean foram classificadas como variáveis de intensidade, pois estão diretamente ligadas à intensidade dos eventos de transporte.

Para ser classificado como evento de transporte de aerossóis, a observação tinha que atender a duas condições: 1) apresentar valor de qualquer das variáveis de dimensão em pelo menos duas vezes o desvio padrão acima da média da variável em questão para todas as observações; 2) apresentar valor de pelo menos duas vezes o desvio padrão acima da média de qualquer uma das variáveis de intensidade. Essa metodologia de classificação foi utilizada a fim de identificar eventos mais intensos, nos quais ficam mais claros os efeitos do aerossol, e assim estudá-los. Eventos menores e menos intensos não foram analisados, porém podem ter efeitos significativos. Estes efeitos podem ser investigados a partir da eficiência diária de forçamento radiativo (ver seção 3.9) calculada neste estudo, que é representativa para o aerossol e independe da intensidade ou tamanho do evento. 
No período utilizado, foi identificado um total de 202 dias com eventos de transporte de aerossóis na região. É importante reforçar que isso não significa que neste período houve apenas 202 dias em que ocorreram transporte de aerossóis, mas sim que estes foram os eventos com maior intensidade e dimensão encontrados segundo essa metodologia. Após a identificação dos 202 dias, eles foram analisados separadamente, e foram retirados os eventos que ocorreram fora do período que vai de dezembro a maio. Posteriormente foram identificados dias diferentes que correspondiam a um mesmo evento, a fim de classificar dias seguidos de presença de aerossóis dentro de um mesmo evento de emissão contínua de areia caso isso tenha ocorrido. Para essa identificação foram utilizadas informações não apenas dos dias encontrados segundo a metodologia, mas sim de todos os dias, além de dados de AOD dos sítios do AERONET. Através da AOD média diária tanto do MODIS quanto do AERONET foi possível identificar diferentes eventos de emissão de areia pelo aumento contínuo (durante um mesmo evento) ou intermitente (durante eventos distintos) da profundidade óptica. No gráfico da AOD média diária dos sítios AERONET no caminho das plumas (ver seção 4.1, figura 15) é possível identificar esses eventos pelo aumento da AOD, porém, tendo a ciência de que nem todo aumento da AOD está associado à passagem de plumas de aerossol (a passagem de plumas de queimada poderia ser uma causa, mas com propriedades ópticas significativamente diferentes). Assim, os eventos de transporte identificados sobre o oceano, eram acompanhados desde quando ainda estavam sobre o continente, através, principalmente da AOD nos sítios da AERONET. Após esse procedimento, o número total de eventos diminuiu para 45.

\subsection{Identificação da origem das plumas de aerossol}

Durante esse procedimento de identificação dos eventos, notou-se que muitas plumas não eram detectadas por nenhum dos sítios do AERONET no caminho entre a depressão de Bodelé, e a costa da África. Isso levantou o questionamento sobre a origem de outras fontes de emissão de aerossóis. Middleton \& Goudie (2001) investigaram as origens dos aerossóis transportados do Saara e identificaram, além da depressão de Bodelé, outra região compreendida entre Mali, Mauritânia e Argélia como fonte de aerossóis transportados. Para identificar 
possíveis outras origens, além de produtos já citados, também foi utilizado o modelo de dispersão Hysplit (Draxler et al., 2010). O Hysplit (HYbrid Single-Particle Lagrangian Integrated Trajectory) é um modelo numérico da NOAA (National Oceanic and Atmospheric Administration) utilizado para simular trajetórias desde simples parcelas de ar, até da dispersão e deposição de constituintes na atmosfera (Draxler et al., 2010). No contexto deste trabalho, foram realizadas simulações de trajetória inversa tendo a localização do sítio AERONET em Cabo Verde como ponto final, ou seja, foram identificadas as origens das parcelas de ar transportadas para essa região nos dias em que foi identificada pluma de aerossóis. Foram feitas simulações para parcelas em altitudes entre 1500 e 2000 metros sobre Cabo Verde, por essa ser a altitude aproximada da base das plumas de aerossóis transportadas para o oceano. Além das simulações numéricas de trajetórias com o Hysplit, também foram utilizadas as informações de AOD dos sítios AERONET e dos produtos de satélite já citados, informações de vento em superfície (também disponível junto aos produtos CERES) e até mesmo imagens no espectro visível, disponíveis em https://worldview.earthdata.nasa.gov/. Todas as informações foram usadas em conjunto para determinar a origem aproximada das plumas de aerossol. Através dessa metodologia foi possível identificar, além da depressão de Bodelé, uma outra origem dos aerossóis numa região compreendida entre o norte de Mali e Mauritânia, e o sul da Argélia. Essa região da África ocidental é, segundo Chiapello et al. (1997), a origem de aproximadamente 50\% dos eventos de transporte de aerossol identificados em Cabo Verde.

\subsection{Filtragem dos dados}

O estudo é focado na análise dos impactos radiativos do aerossol do deserto do Saara no balanço de radiação. Sendo assim, a filtragem dos dados é necessária para evitar efeitos associados a outras origens, e ter resultados causados apenas pelos aerossóis em questão. Os dados foram filtrados para três componentes indesejados: aerossóis de queimada, nuvens e glint.

A região subsaariana é uma importante fonte de aerossóis de queimada, especialmente entre dezembro e fevereiro (Duncan et al., 2003). Esse tipo de aerossol interage de forma diferente com a radiação em relação à areia, e pode se 
misturar às plumas de areia (Milton et al., 2008). Então, todos os eventos de transporte de areia foram analisados para excluir eventos que tivessem uma grande concentração desse tipo de aerossol. Essa análise foi feita com os dados de distribuição de tamanho, da AERONET em Dakar e Cabo Verde em todos os casos, com a inclusão de outros sítios da região quando disponíveis, e dando atenção especial às plumas que tinham origem mais ao sul. Foi observado que as partículas de areia deixam o continente africano com tamanho predominantemente em torno de 4 a $5 \mu \mathrm{m}$, enquanto que o material originado de queimada tem tamanho inferior a $1 \mu \mathrm{m}$. Então todos os eventos em que foram identificadas quantidades elevadas de aerossóis da moda fina foram excluídos e não utilizados nos passos seguintes do estudo. A identificação de quantidades elevadas se deu pelo aumento na concentração volumétrica de aerossóis da moda fina, como observado na figura 9 , que difere do comportamento sem aerossóis de queimada, quando a concentração volumétrica de aerossóis diminui na região da moda fina. Com isso, o número de eventos passou de 45 para 40. É importante destacar que utilização de informações pontuais de sítios da AERONET pode trazer limitações devido a possíveis gradientes de mistura de aerossóis, então deve-se considerar possível presença, mesmo que pequena, de aerossóis da moda fina. A figura 9 mostra um dos eventos fitrados. Note que a concentração volumétrica, em $\mathrm{dV}(\mathrm{r}) / \mathrm{d} \ln (\mathrm{r})$, de aerossóis com raio em torno de 0,1 $\mu \mathrm{m}$ (moda fina) é aproximadamente um terço da concentração de partículas com raio em torno de $2 \mu \mathrm{m}$. 


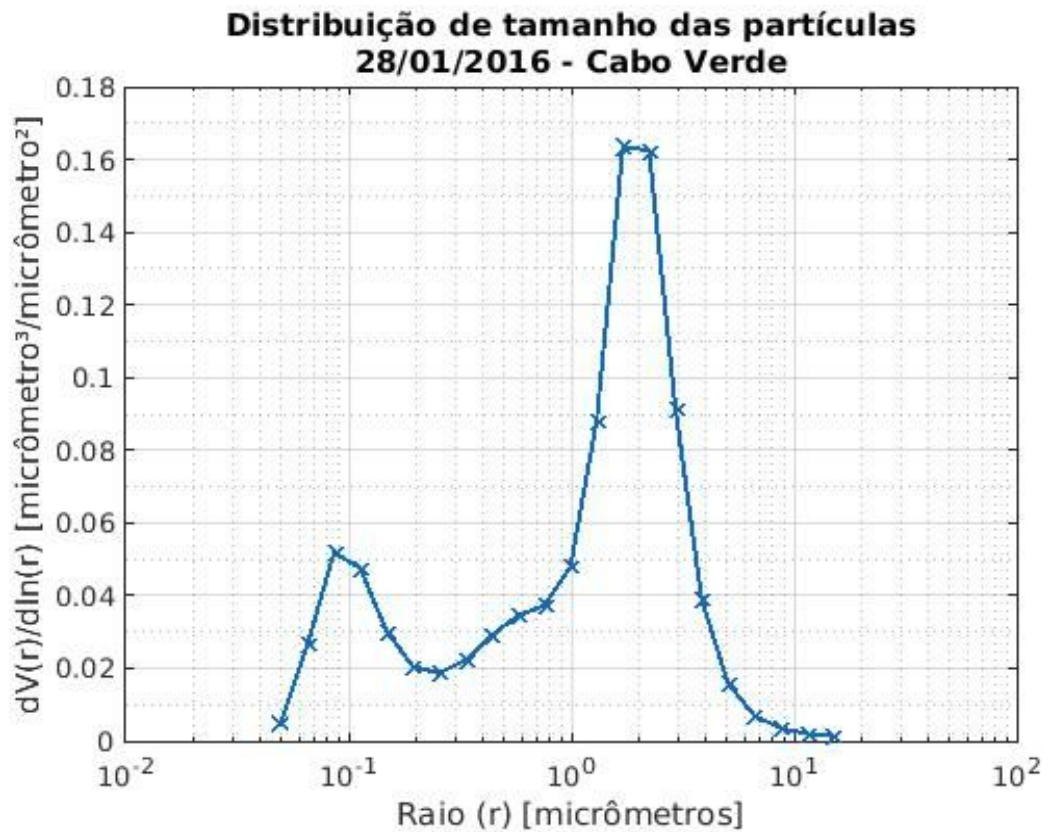

Figura 9 - Distribuição de tamanho das partículas em 28/01/2016 no sítio AERONET de Cabo Verde. Evento de transporte de aerossóis não usado devido à grande presença de aerossóis da moda fina, possivelmente originários de queima de biomassa.

Com relação às nuvens foram utilizados apenas pixels com fração de nuvens igual a zero. Porém, para minimizar também o efeito de nuvens que tivessem em regiões próximas do pixel em questão, foram excluídos todos os pixels que tivessem qualquer outro pixel com fração de nuvens igual ou superior a 10\% num raio de 40 $\mathrm{km}$ (duas vezes o diâmetro dos pixels utilizados). Essa filtragem reduziu significativamente a quantidade disponível de pixels validados especialmente próximo à América do Sul, quando as plumas estão mais próximas da ZCIT, porém ainda assim foram mantidos os filtros, prezando pela representatividade real dos resultados em referência ao que era o foco do estudo.

Glint se refere à reflexão especular do disco solar por uma superfície aquática. A figura 10 ilustra um exemplo desse fenômeno. 


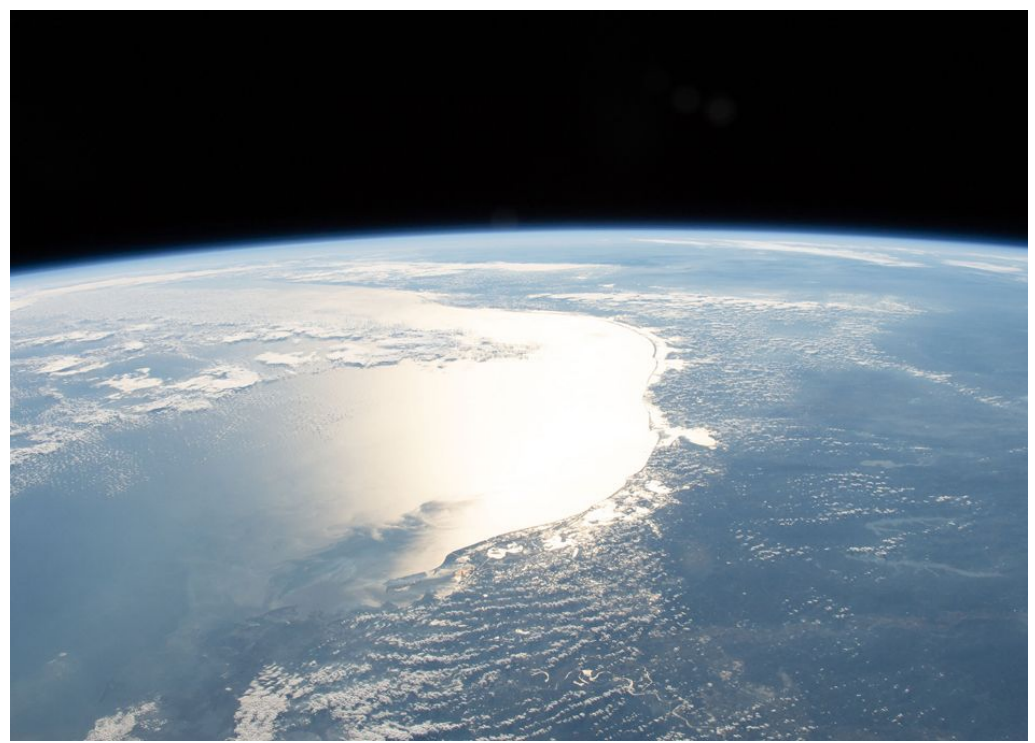

Figura 10 - Glint solar no Golfo do México (imagem disponível em: http://spaceref.com/2019/02/. Acesso em abril de 2020)

Regiões de glint representam ruído aos dados deste estudo, uma vez que o aumento da radiância causado pelo glint não representa qualquer tipo de interação com os aerossóis. Para remoção dos efeitos de glint foi aplicado o método descrito por Cox \& Munk (1954), que apesar de antigo, foi reavaliado em diversos estudos mais recentes, como Zhang \& Wang (2010).

Neste estudo, assim como em Li et al. (2004), observou-se uma relação linear entre a profundidade óptica do aerossol oriundo do deserto do Saara e o forçamento radiativo, no espectro solar, no topo da atmosfera. Sendo assim, os fluxos de onda curta no topo da atmosfera foram utilizados para avaliar a qualidade da filtragem dos dados. Após os procedimentos de filtragem ainda foram identificados entre $2 \%$ e $5 \%$ do total de pixels que se encontravam fora do padrão linear de relação entre irradiância solar ascendente no TOA e AOD. Eles foram retirados quase em sua totalidade após a aplicação de regressão linear utilizando o método dos mínimos quadrados. Os pixels classificados como outliers e removidos da base de dados de irradiância no espectro solar no TOA também foram removidos da base de dados dos fluxos em superfície, na atmosfera e do espectro terrestre. 


\subsection{Etapas do transporte}

Um dos objetivos deste trabalho é entender a evolução das plumas de aerossol, do ponto de vista radiativo durante o transporte. Sendo assim, após todos os procedimentos já descritos, todos os pixels foram divididos em três etapas. Cada etapa corresponde a uma faixa longitudinal que está associada a uma fase do transporte entre África e América do Sul. Ott et al. (1991) estimaram o tempo do deslocamento do continente africano até a América do Sul em aproximadamente 7 dias. Essa informação se juntou aos padrões de deslocamento longitudinal das plumas (figura 11) com a intenção de dividir as três etapas.

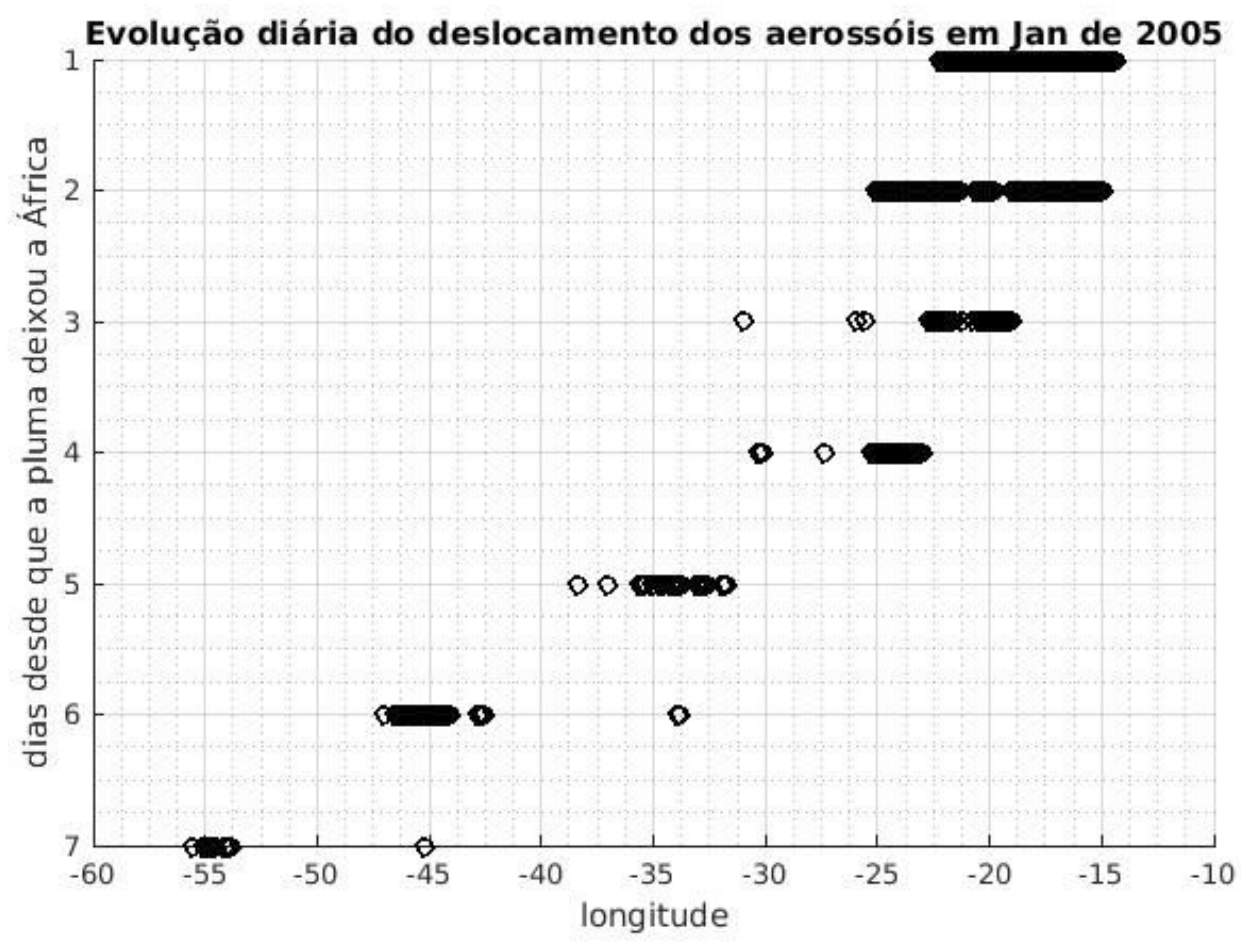

Figura 11 - Deslocamento longitudinal dos pontos observados em evento de transporte de 18 a 24 de janeiro de 2005.

O padrão mais comumente observado foi das plumas localizadas entre 0 arquipélago de Cabo Verde $\left(\sim 25^{\circ} \mathrm{W}\right)$ e costa africana entre os primeiros dois dias do transporte. Entre o terceiro e o quinto dia, elas se encontram numa região intermediária entre a África e a América do Sul, e após o quinto dia elas se aproximam do continente sul americano. Esse padrão, entretanto, apesar de recorrente não é exato, uma vez que alguns eventos apresentam emissão contínua de aerossóis (logo, há presença de aerossóis ainda entre Cabo Verde e o continente 
após o terceiro dia), enquanto em outros a pluma é depositada no oceano antes mesmo de chegar ao continente. Sendo assim, as três etapas do transporte foram determinadas de forma subjetiva. A etapa 1, fase inicial do transporte, corresponde a pixels em longitudes a leste de $25^{\circ} \mathrm{W}$; a etapa 2, fase intermediária do transporte, corresponde a pixels em longitudes entre $25^{\circ} \mathrm{W}$ e $40^{\circ} \mathrm{W}$; e a etapa 3 , fase final do transporte, corresponde a pixels em longitudes a oeste de $40^{\circ} \mathrm{W}$. As três etapas tratam apenas de pontos sobre o oceano Atlântico. As observações sobre 0 continente, na América do Sul, são discutidas separadamente. A figura 12 mostra a disposição nas três etapas de todos os pixels que passaram pela filtragem descrita anteriormente.

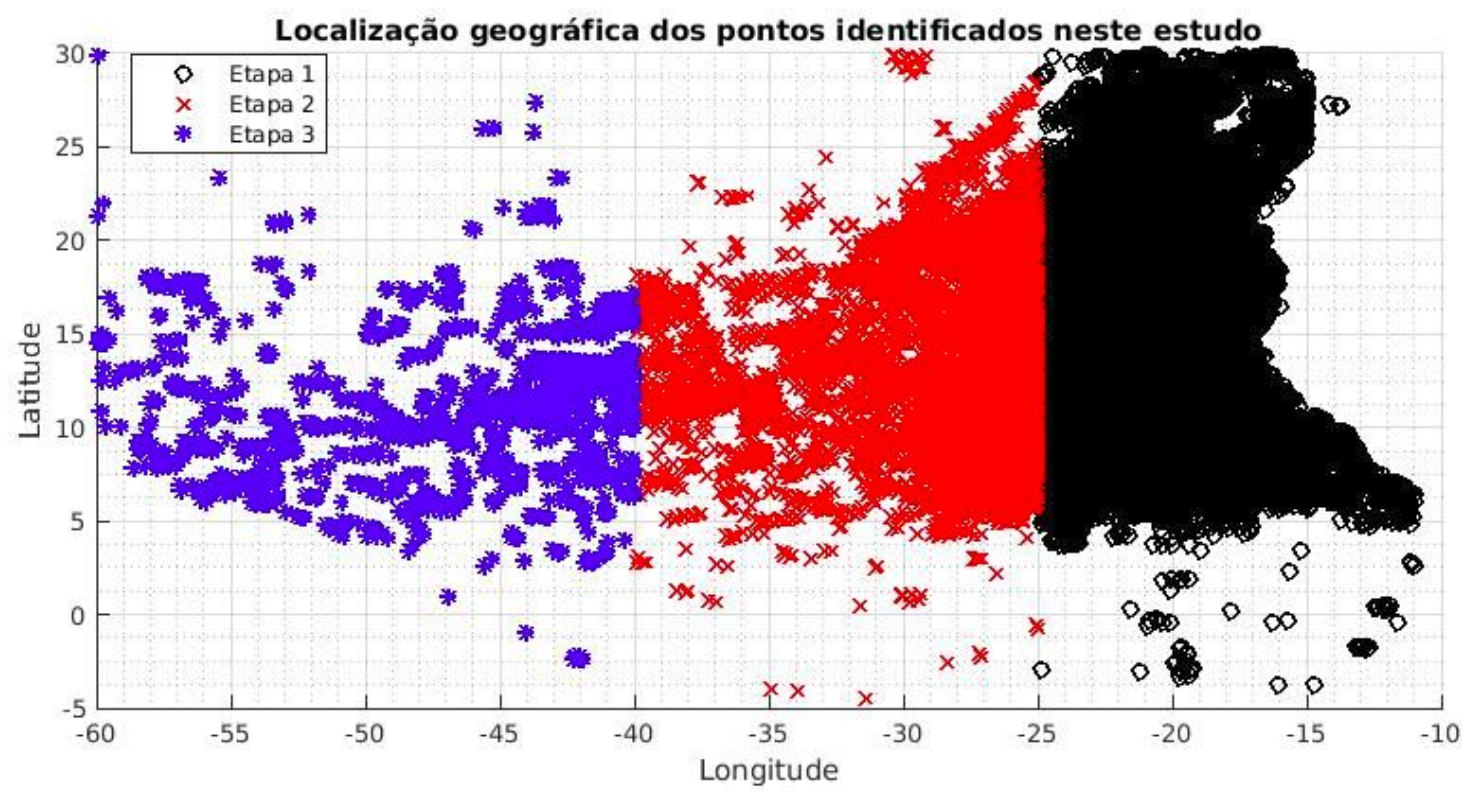

Figura 12 - Localização geográfica dos pontos sobre o oceano referentes aos 40 eventos utilizados neste estudo, destacando as três etapas de transporte.

Para a identificação dos pixels associados às plumas de aerossol do Saara sobre o continente sul-americano, foram primeiramente identificados os eventos que chegaram à Amazônia, pela verificação de plumas que ainda puderam ser observadas em latitudes a sul de $6,5^{\circ} \mathrm{N}$ e longitudes a oeste de $40^{\circ} \mathrm{W}$. A partir do primeiro dia em que a pluma foi observada dentro desses limiares, foram buscados pixels sobre o continente com AOD consistente com o observado sobre o oceano, dentro de um raio de $500 \mathrm{~km}$ do ponto observado no dia anterior. O valor de $500 \mathrm{~km}$ de raio foi escolhido baseado no que foi observado da chegada das plumas de 
aerossol à América do Sul e nas informações disponíveis sobre o tempo do transporte. A maioria das plumas observadas neste estudo adentra o continente numa faixa que vai do Cabo Orange, no norte do Amapá, até aproximadamente a cidade de Nova Amsterdã, na Guiana. Baseado na distância aproximada entre Dakar, no Senegal, e o Cabo Orange $(\sim 3900 \mathrm{~km})$ e no período médio do deslocamento entre a África e América do Sul relatado por Ott et al. (1991) e também observado neste estudo ( $\sim$ dias), tem-se um deslocamento das plumas de aproximadamente $550 \mathrm{~km}$ por dia. Porém preferiu-se o uso do valor de $500 \mathrm{~km}$ para ser mantida uma margem de segurança e minimizar a possibilidade de qualquer observação sem relação com a areia do deserto. Quanto à consistência da AOD sobre o continente, foi utilizado o limiar de $80 \%$ do valor da AOD observada no pixel sobre o oceano. O procedimento foi repetido para identificar plumas no segundo dia sobre o continente, porém utilizando as informações do ponto observado no dia anterior, quando elas já não estavam sobre o oceano. Sendo assim, qualquer pixel sobre a Amazônia que tivesse a AOD mais de $20 \%$ menor e/ou estivesse a uma distância maior do que 500 km de qualquer pixel identificado no dia anterior, não era considerado. Essa metodologia não considera possíveis misturas entre aerossóis do Saara com aerossóis de fontes sobre o continente como condição para invalidar pixels. Por esse motivo, há a possibilidade de observações com presença de aerossóis do deserto do Saara sobre o continente na verdade incluírem também aerossóis de outras fontes. Esse é um fenômeno a se destacar e que será discutido na seção 4.3. Os limites geográficos dos dados utilizados são os mesmos mostrados na figura 12 , logo, não há nenhuma observação a oeste de $60^{\circ} \mathrm{W}$ e nem ao sul de $5^{\circ} \mathrm{S}$.

\subsection{Forçamento Radiativo de Aerossol (FRA) e Eficiência Radiativa de Aerossol} (ef)

Para estudar os efeitos do aerossol, é calculada uma variável chamada Forçamento Radiativo de Aerossol (FRA). O FRA é resultado da diferença entre o fluxo ou o saldo de radiação de um caso poluído (onde "caso poluído" é tratado como sinônimo de "caso presença de aerossóis", i.e., AOD alto) e um caso limpo 
(sem a presença de aerossóis, i.e., AOD próximo de 0). Neste estudo tratamos da diferença entre o saldo de radiação, na seguindo a forma:

$$
\mathrm{FRA}=\mathrm{S}_{\text {poluido }}-\mathrm{S}_{\text {limpo }}
$$

Onde $\mathrm{S}_{\text {limpo }}$ representa o saldo de radiação num cenário limpo e $\mathrm{S}_{\text {poluido }} \mathrm{o}$ saldo de radiação na presença de aerossóis. O sinal do FRA indica o saldo positivo ou negativo, que representa maior retenção ou perda de energia radiativa, respectivamente, pelo sistema. Os cenários limpos foram utilizados de duas formas. Para todos os fluxos radiativos no espectro terrestre (TOA, atmosfera e superfície) e em superfície e na atmosfera para o espectro solar, os cenários limpos foram observacionais. Os cenários limpos foram identificados a partir das observações que tiveram a média abaixo de um desvio padrão da média dessas variáveis para todo o período. Porém, para melhor filtragem de qualquer presença significativa de aerossóis, foram utilizados apenas os pixels dos casos limpos em que a AOD era menor que 0,1. Para minimizar qualquer efeito de diferentes geometrias (ângulos zenital e azimutal do sol e do satélite), foram escolhidos cenários limpos que tenham ocorrido num dia em que a diferença para o dia poluído seja múltiplo de 16 (a órbita do satélite se repete a cada 16 dias), e em até 30 dias de diferença (para minimizar o efeito do movimento aparente do sol) da data do dia poluído, em qualquer ano do período de estudo. Assim, um dia poluído ocorrido em 01 de janeiro de qualquer ano, seria comparado a um cenário limpo ocorrido entre 02 de dezembro e 31 de janeiro de qualquer ano, contanto que esse dia tivesse ocorrido a um número $\mathrm{x}$ dias que fosse múltiplo de 16.

Para os fluxos radiativos no espectro solar no TOA, os casos limpos foram resultados de simulações, utilizando o código de transferência radiativa LibRadtran. No input do código, foi utilizada a mesma geometria do sol de cada pixel poluído que passou pela filtragem, a aproximação da atmosfera pseudo esférica, uma atmosfera padrão tropical, albedo de superfície do oceano considerando refletância não lambertiana (disponível na biblioteca do LibRadtran) e aerossóis de origem marinha de background com AOD igual a 0,05. Com isso tentou-se reproduzir o mais próximo possível as características do cenário sem a presença dos aerossóis do deserto.

Nos pixels sobre o continente, já na América do Sul, os fluxos radiativos foram calculados apenas para o espectro solar no TOA, uma vez que a este fluxo 
radiativo é dado destaque quando as plumas estão sobre o oceano, como é discutido na seção 4.2. O procedimento de simulação dos fluxos radiativos para pixels limpos sobre o continente utiliza os mesmos inputs das simulações sobre o oceano, com a diferença no albedo de superfície, que nos pixels sobre o continente é o de floresta perene de folhas largas (do inglês evergreen broadleaf forest), também considerando a refletância não lambertiana. A escolha desse tipo de superfície nas simulação reflete a utilização dos dados observacionais: foram utilizados apenas pixels de superfície classificados como de floresta perene de folhas largas, segundo o índice de tipo de superfície (surface type index) atrelado ao produto do CERES utilizado. Esse é o tipo de superfície de boa parte da principal região de entrada dos aerossóis no continente, que, como já citado, vai do norte do Amapá até a Guiana, logo, não houve diminuição significativa no total de pixels sobre o continente.

Optou-se por usar simulações para os cenários limpos por, nas simulações, a irradiância ascendente apresentar um menor desvio padrão $\left(\sim 2,9 \mathrm{~W} / \mathrm{m}^{2}\right)$ do que nos cenários limpos observacionais $\left(\sim 9,5 \mathrm{~W} / \mathrm{m}^{2}\right)$. Este desvio padrão se refere à distribuição da irradiância ascendente no TOA para os pixels observais considerados limpos (com AOD variando em torno de 0,05 e nunca acima de 0,1) e dos pixels limpos das simulações (com AOD sempre igual a 0,05). Essa diferença poderia ser resultado, além da pequena variação da AOD, de um possível efeito indesejado no cenário limpo observacional, que poderia ser causado pela diferença na geometria solar (os cenários limpos observacionais eram de outros momentos, e apesar do esforço para minimizar as diferenças na geometria, elas ainda existem) ou por outros fatores, como componentes atmosféricos. Nos cenários limpos simulados numericamente o perfil atmosférico nunca muda (atmosfera tropical padrão), então este também é um fator que pode gerar diferenças entre o cenário poluído e o cenário limpo, além da presença do aerossol. O desvio padrão da irradiância ascendente no TOA simulada representa aproximadamente $2,5 \%$, e se aproxima dos $2,2 \%$ de incerteza do instrumento CERES.

Parte do forçamento radiativo apresentado neste trabalho é instantâneo, ou seja, representa o que foi observado no momento da medida pelo satélite, e por esse motivo traz consigo incertezas associadas aos diferentes valores de ângulo 
zenital solar em cada momento medido. Essas incertezas associadas às diferentes geometrias e também aos diferentes perfis atmosféricos ficam claras na demonstração dos resultados instantâneos, mas também reverbera nas estimativas diárias, que como serão descritas na seção 3.9, partem de regressão linear destes dados instantâneos.

A partir do forçamento radiativo de aerossol instantâneo, é calculada a eficiência do forçamento. Seguindo a convenção de Satheesh \& Ramanathan (2000), adotada por outros autores como Li et al. (2004), a eficiência de forçamento radiativo de aerossol é definida pela derivada do FRA em relação à $A O D$, como ilustrado em (11).

$$
\text { ef }=d F R A / d \tau
$$

Onde ef é a eficiência de forçamento radiativo e $\tau$ é a AOD. Em outras palavras, a eficiência de forçamento radiativo pode ser definida como o forçamento radiativo por unidade de AOD. Neste trabalho ela é calculada apenas para o espectro solar no TOA. O procedimento de cálculo seguiu da seguinte forma: depois de calculado o FRA para cada ponto, de cada etapa do transporte, e da remoção de outliers (como descrito na seção 3.6), é realizada uma regressão linear através do método dos mínimos quadrados, e o coeficiente angular da regressão linear é a eficiência de forçamento. O método foi aplicado para as três etapas do transporte.

É importante destacar que a eficiência de forçamento radiativa também é calculada para medidas instantâneas do forçamento radiativo, logo, traz consigo as incertezas associadas à variação do ângulo zenital solar dentro da amostragem. Por esse motivo apresentam elevada incerteza, que é calculada baseada no desvio padrão do FRA para intervalos pequenos de AOD (tendo neste trabalho o valor de $0,2)$. As estimativas de forçamento radiativo de aerossol e de eficiência de forçamento radiativo apresentadas neste trabalho são mais úteis do ponto de vista do tempo, uma vez que a partir delas é possível estimar o efeito local e a curto prazo do aerossol no balanço de energia, e consequentemente na termodinâmica da atmosfera. 


\subsection{Eficiência Diária de Forçamento Radiativo $\left(\mathrm{ef}_{\mathrm{dia}}\right)$}

Uma outra abordagem para analisar o impacto radiativo do aerossol é através da eficiência diária de forçamento radiativo. Para o cálculo dessa variável, a irradiância no espectro solar ascendente no TOA dos casos poluídos (em que poluído = com presença de aerossóis) é transformada em albedo, a partir da divisão pela irradiância solar descendente nesse ponto, e é utilizada a variação deste albedo em função da variação da $A O D$, na forma $\frac{d(\text { albedo })}{d(A O D)}$. Então há de se observar que daqui em diante neste trabalho, o termo albedo se refere a este albedo no topo da atmosfera, e não de superfície. Quando tratado o albedo de superfície, este será deixado claro. Posteriormente é feita uma integração para todos os valores de ângulo zenital solar, do nascer ao pôr do sol. Entretanto, devido à órbita polar dos satélites Terra e Aqua, não há disponibilidade de observações em todos os instantes, algo que seria necessário para realizar a integração da equação. Devido a essa limitação, neste trabalho foi reproduzida a metodologia utilizada por Li et al. (2004), que utilizaram dados observados de $\frac{d(\text { albedo })}{d(A O D)}$ para os valores de ângulo zenital solar disponíveis para ajustar uma curva, que aqui será chamada curva de albedo, simulada para todos os valores do ângulo zenital solar, do nascer ao pôr do sol, utilizando um código de transferência radiativa.

\subsubsection{Procedimento de cálculo da curva de albedo observada}

Este procedimento foi feito separadamente para cada etapa do transporte utilizando todos os pontos dos satélites Terra e Aqua, independente de data. Os pixels com informações de albedo foram separados de acordo com o seu ângulo zenital solar, de $0^{\circ}$ a $90^{\circ}$, em agrupamentos de $5^{\circ}$. Neste momento, todos os intervalos de ângulo zenital solar que tivessem menos de 200 pontos não foram utilizados. Os agrupamentos que apresentaram amostragem suficiente foram separados em intervalos de AOD de 0,4. Menores intervalos de AOD (como 0,1) representariam melhor a relação $\frac{d(\text { albedo })}{d(A O D)}$, mas perderiam amostragem (haveriam menos pontos neste intervalo), enquanto que intervalos maiores (como valores em torno de 1) teriam maior amostragem, mas poderiam esconder pequenas variações da relação $\frac{d(\text { albedo })}{d(A O D)}$, e por estes motivos utilizou-se o valor de 0,4. Após a separação 
dos intervalos de AOD dentro de cada intervalo de ângulo zenital, novamente, os agrupamemtos que tivessem uma amostragem menor que 200 pontos não foram utilizados no passo seguinte. Dentro de cada intervalo com amostragem suficiente, foi realizada uma regressão linear através do método dos mínimos quadrados. $O$ coeficiente angular da reta resultante desta regressão é o $\frac{d(\text { albedo })}{d(A O D)}$ naquela faixa de ângulo zenital. Se houver mais de um intervalo de AOD com amostragem suficiente para a realização da regressão linear, o valor de $\frac{d(\text { albedo })}{d(A O D)}$ para o intervalo de ângulo zenital solar será a média de todos os intervalos de AOD. Caso haja apenas um intervalo de AOD com amostragem suficiente, este representa o $\frac{d(\text { albedo })}{d(A O D)}$ daquela faixa de ângulo zenital solar.

Devido à falta de disponibilidade de observações para todos os valores do ângulo zenital solar, do nascer ao ocaso solar, apenas alguns intervalos podem ser calculados. Para a extrapolação desses valores observados para todos os valores de ângulo zenital solar, são utilizadas simulações no LibRadtran que gerem curvas de albedo com melhor ajuste aos valores observados. A pouca amostragem disponível para a etapa 3 (cerca de 3000 pontos para cada origem, contra cerca de 20000 pontos para cada origem na etapa 1), resultou numa maior dificuldade de fazer estimativas para essa etapa. Para essa região, ao invés do limiar de 200 pontos para cada intervalo de ângulo zenital solar, foi utilizado o limiar de 100 pontos. Mesmo assim foi possível calcular o valor de $\frac{d(\text { albedo })}{d(A O D)}$ apenas para três intervalos de ângulo zenital solar para os casos do norte de Mali e apenas para um intervalo nos casos originados em Bodelé. Contudo, a diminuição na qualidade do ajuste linear da relação entre FRA instantâneo e AOD pode ter prejudicado a estimativa de $\frac{d(\text { albedo })}{d(A O D)}$, uma vez que a dispersão dos três pontos calculados a partir dos eventos de Mali não teve um padrão similar ao observado no de outras etapas (fato apresentado e discutido nos resultados). Essa diminuição da qualidade do ajuste linear fica clara com os valores do chi-quadrado reduzido, apresentados e discutidos na seção 4.2. Por esse motivo, não foi possível fazer ajustes consistentes da reta simulada para a etapa 3 , e então a eficiência diária de forçamento radiativo só pôde ser calculada para as etapas 1 e 2. 


\subsubsection{Procedimento de ajuste da curva de albedo simulada}

Com a identificação de mais de uma origem das plumas de aerossol, as propriedades ópticas de cada origem foram simuladas através do código Mie (Wiscombe, 1980), tendo como input o índice de refração e a distribuição de tamanho médios estimados pelo AERONET de Cabo Verde para três eventos de cada origem. Estes eventos foram em maio de 2003, fevereiro de 2012 e abril de 2012 para os aerossóis de Mali, e fevereiro de 2008, março de 2010 e abril de 2015 para os aerossóis de Bodelé. As saídas foram usadas dentro do código LibRadtran com o solver DISORT, para simular uma camada de aerossóis de $1 \mathrm{~km}$ a $5 \mathrm{~km}$ de altitude, seguindo a estrutura vertical das plumas observada por Liu et al. (2012) e reafirmada com o que foi observado pelo lidar do CALIPSO.

O albedo simples, no entanto, tem o seu valor em $550 \mathrm{~nm}$ determinado em cada simulação. Ele é a variável de controle utilizada para encontrar a curva de albedo simulada que tenha o melhor ajuste à observada. As simulações da irradiância solar ascendente no TOA são então realizadas para todos os valores do ângulo zenital solar, do nascer ao pôr do sol, para a localidade em questão e dia do ano, variando a AOD de 0 a 1, em intervalos de 0,2. O albedo é calculado, dividindo a irradiância calculada numericamente pela irradiância solar descendente no TOA, e, com o albedo em diferentes valores de AOD, é então calculada a curva de albedo. $O$ melhor ajuste da curva simulada é estimado através do menor valor da raiz do erro médio quadrático entre simulação e observação. O chi-quadrado reduzido é também calculado para avaliar a qualidade da curva simulada em relação às observações. Os ajustes, bem como a raiz do erro médio quadrático, chi-quadrado reduzido e o albedo simples associado a cada etapa do transporte são apresentados e discutidos juntamente com os resultados.

\subsubsection{Integração da eficiência diária de forçamento radiativo}

Com a utilização do $\frac{d(a l b e d o)}{d(A O D)}$ para todos os valores de ângulo zenital solar então é possível integrar uma equação, do nascer ao pôr do sol, que estima a eficiência diária de forçamento radiativo seguindo a equação proposta por Rajeev \& Ramanathan (2001): 


$$
e f(\text { dia })=\frac{S o}{2 \pi}\left(\frac{d 0}{d}\right)^{2} \int_{-h 0}^{h 0} \cos (\theta)\left[\frac{d(\text { albedo })}{d(A O D)}\right] d \theta
$$

Onde $\mathrm{S}_{0}$ é o fluxo solar médio por unidade de área no nadir à distância média entre o Sol e a Terra $\left(S_{0}=1367 \mathrm{~W} / \mathrm{m}^{2}\right), d_{0}$ é a distância média entre Sol e Terra, $d$ é a distância entre eles no dia a ser calculado e $h_{0}$ é o ângulo horário. Neste trabalho propõe-se a integração desta equação não em função do ângulo horário, mas sim em função do tempo (13). As duas equações representam formas diferentes de abordar a equação, mas que resultam num resultado similar.

$$
e f(d i a)=\frac{S o}{t s o l}\left(\frac{d 0}{d}\right)^{2} \int_{t i}^{t f} \cos (\theta)\left[\frac{d(\text { albedo })}{d(A O D)}\right] d \theta
$$

Em que tsol é o tempo (em horas) entre o nascer do sol e o pôr do sol, ti é a hora do nascer do sol, e tf é a hora do pôr do sol. A integração foi feita em intervalos de 1 segundo (1/3600 hora).

Neste estudo foram calculadas as eficiências diárias para todos os meses de janeiro a julho, com a intenção de identificar possíveis variações sazonais e para possibilitar a comparação com resultados apresentados por Li et al. (2004), que calcularam a eficiência diária de forçamento radiativo do aerossol do Saara para o mês de julho. Para representar a geometria solar de cada mês foi utilizada a declinação solar do dia 15 de cada um desses meses. Testes de sensibilidade mostraram que a adoção de um dia fixo, dia 15, para representar a variabilidade de todo mês resultou em erros da ordem de $1 \%$ a $3 \%$ no valor da eficiência diária de forçamento radiativo para o primeiro e o último dia do mês. No que diz respeito às coordenadas geográficas, foram utilizadas as latitudes e longitudes médias das plumas em cada etapa do transporte. Com essas informações foi possível calcular a declinação solar e posteriormente o ângulo horário. O ângulo horário é utilizado para calcular ti, tf e tsol, e também para calcular o ângulo zenital solar em cada segundo do dia, de acordo com a equação (14), definida em Liou (2002):

$$
\cos (\theta)=\operatorname{sen}(\varphi) * \operatorname{sen}(\delta)+\cos (\varphi) * \cos (\delta) * \cos (h 0)
$$

Em que $\theta$ é o ângulo zenital do sol, $\varphi$ é a latitude e $\delta$ é a declinação solar. Contudo, o maior desafio da estimativa de forçamento diário está na informação de $\frac{d(\text { albedo })}{d(A O D)}$ para todos os valores do ângulo zenital solar, do nascer ao pôr do sol. 
Por fim, as eficiências diárias de forçamento radiativo foram utilizadas juntamente com a AOD média diária do produto CERES-SSF1deg-Ed4A para calcular o Forçamento Radiativo Médio Diário (em $\mathrm{W} / \mathrm{m}^{2}$ dia), pela multiplicação simples entre os dois valores. 
Capítulo 4: Resultados 


\subsection{Eventos de transporte de aerossóis, origens e padrões associados}

Ao todo foram analisados 40 eventos de transporte de aerossóis do deserto do Saara neste estudo. Esse número corresponde ao número de eventos encontrados conforme a metodologia já apresentada, que passaram na filtragem, e tratam de plumas apenas de aerossol oriundo do deserto, sem presença significativa de aerossóis de queima de biomassa na África subsaariana (verificado através da distribuição de tamanho do AERONET). No que diz respeito à intensidade dos eventos considerada na metodologia, as figuras 13 e 14 mostram as distribuições das médias e do quantil de $95 \%$ da AOD de todas as observações. A linha vermelha indica o valor de duas vezes o desvio padrão acima da média, que é um dos limiares utilizados para classificar dias de transporte de aerossóis.

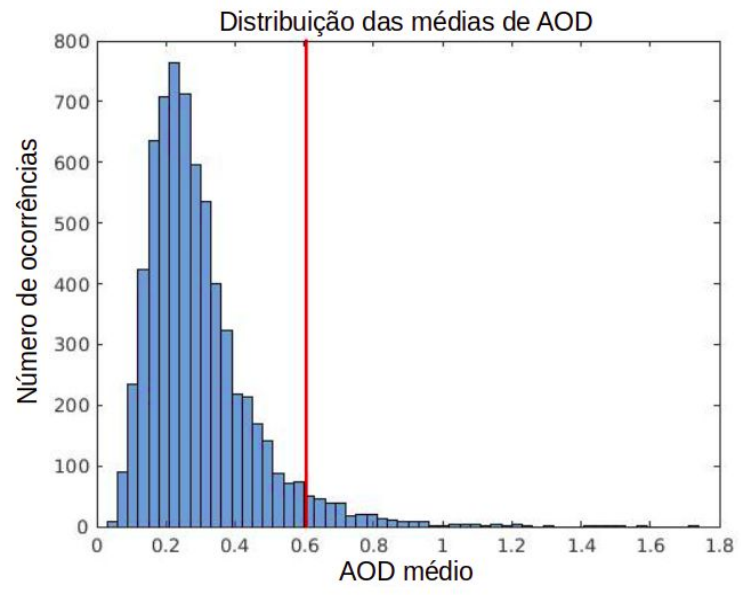

Figura 13 - Distribuição da AOD média

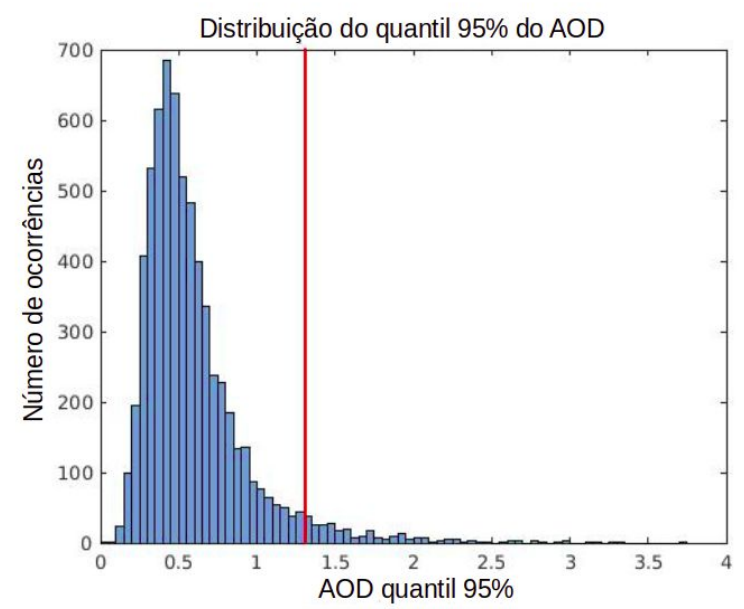

Figura 14 - Distribuição do quantil 95\% da AOD

O processo de identificação de dias de transporte de aerossóis, e posterior separação destes dias em eventos de transporte, também mencionado na metodologia, envolveu a análise da média diária da AOD nos sítios AERONET e do MODIS. A figura 15 mostra a informação utilizada para esse procedimento, referente a um dos eventos de transporte. Na figura é possível identificar a passagem de plumas de aerossol sobre o sítio AERONET de Banizoumbou, no Níger, pelo aumento da AOD. Os vales entre os picos nos valores de AOD caracterizam a ocorrência de eventos diferentes. No caso em questão, há três dias com valores mínimos entre 15 e 17 de março, que separam dois eventos de transporte. Entretanto esse "vale" no gráfico, em alguns casos chegou a ser de apenas dois dias. $O$ aumento da AOD entre os dias 18 e 22 de março corresponde à passagem 
de plumas de aerossol que posteriormente foram identificadas deixando o continente africano e estão incluídas neste estudo.

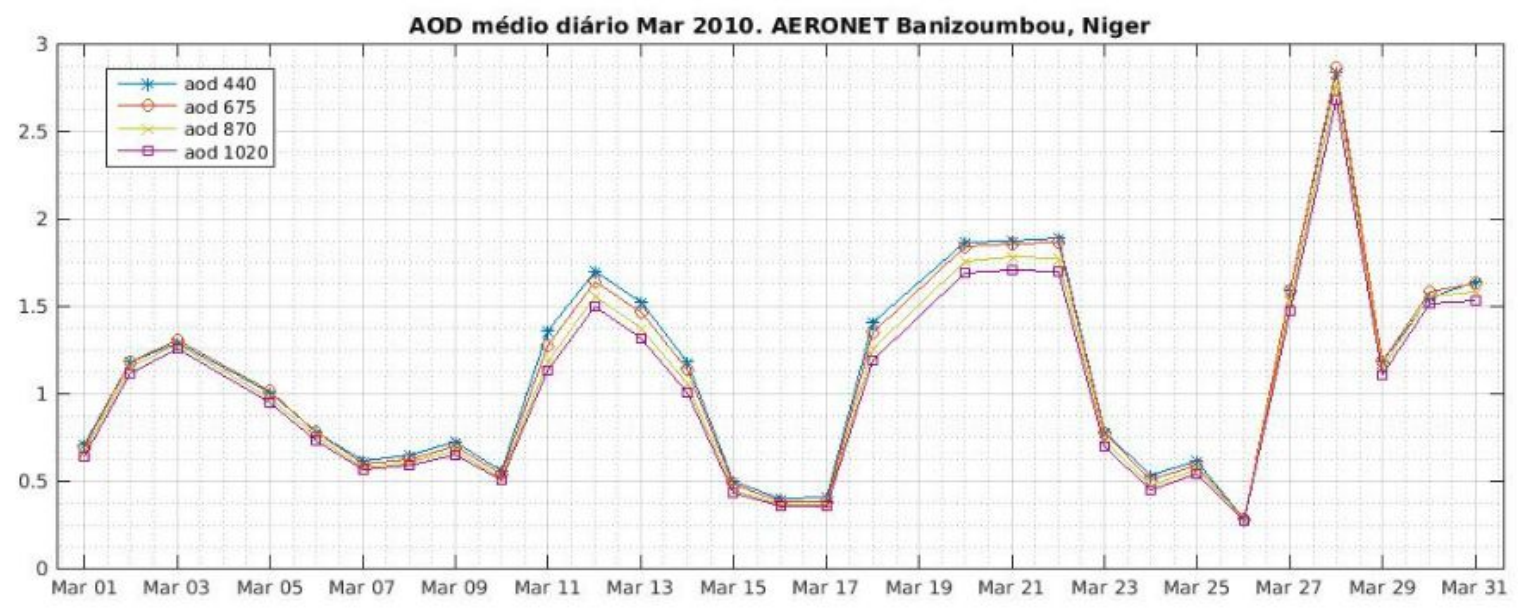

Figura 15 - AOD média diária no sítio AERONET de Banizoumbou, no Níger.

A tabela 1 lista todos os 40 eventos encontrados em ordem cronológica, mostrando sua data de início, o número de dias em que foi possível identificar a pluma de aerossóis formada desde que ela deixa a África, a AOD média do evento no dia inicial segundo o produto MOD04_3k e a origem dos aerossóis, que será discutida em seguida.

Tabela 1 - Eventos de transporte de aerossol

(continua)

\begin{tabular}{|c|c|c|c|}
\hline Data de início & $\begin{array}{l}\text { Número de dias do } \\
\text { evento }\end{array}$ & $\begin{array}{l}\text { AOD média no } \\
\text { primeiro dia } \\
\text { MOD04_3k }\end{array}$ & Origem \\
\hline $13 / 02 / 2001$ & 9 & 1,14 & Norte de Mali \\
\hline $25 / 04 / 2002$ & 10 & 0,72 & Norte de Mali \\
\hline $19 / 05 / 2002$ & 6 & 0,90 & Bodelé \\
\hline $28 / 01 / 2003$ & 6 & 0,68 & Norte de Mali \\
\hline $02 / 03 / 2003$ & 8 & 1,05 & Bodelé \\
\hline $06 / 03 / 2003$ & 9 & 0,62 & Norte de Mali \\
\hline $01 / 05 / 2003$ & 6 & 0,59 & Norte de Mali \\
\hline $08 / 05 / 2003$ & 7 & 0,63 & \\
\hline
\end{tabular}


(continua)

\begin{tabular}{|c|c|c|c|}
\hline Data de início & $\begin{array}{l}\text { Número de dias do } \\
\text { evento }\end{array}$ & $\begin{array}{l}\text { AOD média no } \\
\text { primeiro dia } \\
\text { MOD04_3k }\end{array}$ & Origem \\
\hline $12 / 02 / 2004$ & 7 & 1,03 & Bodelé \\
\hline 04/03/2004 & 14 & 0,93 & Norte de Mali \\
\hline 06/01/2005 & 10 & 0,79 & Bodelé \\
\hline $18 / 01 / 2005$ & 8 & 0,94 & Norte de Mali \\
\hline $13 / 02 / 2005$ & 6 & 0,74 & Norte de Mali \\
\hline $16 / 05 / 2005$ & 4 & 1,02 & Norte de Mali \\
\hline $23 / 05 / 2005$ & 5 & 0,69 & Bodelé \\
\hline 08/032006 & 11 & 1,25 & Indefinida \\
\hline 04/01/2007 & 9 & 0,86 & Indefinida \\
\hline 09/05/2007 & 9 & 1,10 & Bodelé \\
\hline $23 / 02 / 2008$ & 7 & 0,84 & Bodelé \\
\hline $28 / 03 / 2008$ & 8 & 0,81 & Norte de Mali \\
\hline 28/04/2008 & 5 & 0,69 & Norte de Mali \\
\hline $21 / 03 / 2010$ & 8 & 1,57 & Bodelé \\
\hline $23 / 04 / 2010$ & 5 & 0,62 & Bodelé \\
\hline $20 / 05 / 2010$ & 5 & 0,69 & Norte de Mali \\
\hline $27 / 05 / 2010$ & 8 & 1,41 & Bodelé \\
\hline 06/02/2012 & 6 & 1,56 & Norte de Mali \\
\hline $10 / 03 / 2012$ & 8 & 0,88 & Norte de Mali \\
\hline $21 / 03 / 2012$ & 7 & 1,22 & Bodelé \\
\hline 29/04/2012 & 9 & 1,73 & Norte de Mali \\
\hline $16 / 05 / 2012$ & 5 & 0,89 & Norte de Mali \\
\hline $21 / 05 / 2012$ & 4 & 0,75 & Bodelé \\
\hline $25 / 05 / 2012$ & 6 & 0,77 & Bodelé \\
\hline 01/03/2014 & 7 & 0,65 & Norte de Mali \\
\hline
\end{tabular}


(conclusão)

\begin{tabular}{|c|c|c|c|}
\hline Data de início & $\begin{array}{l}\text { Número de dias do } \\
\text { evento }\end{array}$ & $\begin{array}{l}\text { AOD média no } \\
\text { primeiro dia } \\
\text { MOD04_3k }\end{array}$ & Origem \\
\hline $27 / 02 / 2015$ & 6 & 0,81 & Norte de Mali \\
\hline $15 / 04 / 2015$ & 7 & 0,87 & Bodelé \\
\hline $25 / 12 / 2016$ & 7 & 1,21 & Bodelé \\
\hline $28 / 03 / 2017$ & 9 & 0,74 & Norte de Mali \\
\hline $17 / 05 / 2017$ & 6 & 0,75 & Norte de Mali \\
\hline $23 / 03 / 2018$ & 8 & 1,45 & Norte de Mali \\
\hline $31 / 05 / 2018$ & 8 & 0,74 & \\
\hline
\end{tabular}

Na tabela são destacadas duas origens para os aerossóis, além de dois eventos com origem indefinida. Uma das origens corresponde à depressão de Bodelé, região no norte do Chade que já é amplamente documentada como importante fonte de areia para a atmosfera, em especial de areia transportada para a Amazônia (Washington \& Todd, 2005; Koren et al., 2006; Washington et al., 2006). A outra região aqui identificada como norte de Mali, que na verdade corresponde a toda uma região que engloba também o norte da Mauritânia e sul da Argélia, é destacada em trabalhos como os de Middleton \& Goudie (2001) e Gläser et al. (2015) como outra principal fonte dos aerossóis transportados do deserto do Saara, e em alguns trabalhos como Chiapello et al. (1997) e Gläser et al. (2015) é inclusive apontada como mais importante que a depressão de Bodelé no que diz respeito ao transporte de aerossóis a longas distâncias no Atlântico.

Não foi objetivo deste trabalho investigar os padrões atmosféricos associados a cada origem ou até mesmo qual das origens é mais importante no contexto do transporte para a Amazônia. Entretanto, a identificação da origem das plumas de aerossol analisadas neste estudo é importante para comparar seus impactos radiativos, logo, a investigação de padrões associados a cada origem, mesmo que de forma superficial, foi importante para essa identificação. Neste contexto, a não detecção de boa parte das plumas através da AOD pelas estações AERONET que estão no caminho entre a Depressão de Bodelé e o Oceano Atlântico dá argumentos 
para o questionamento sobre uma outra fonte destas plumas além de Bodelé. A figura 16 mostra as localizações das principais estações AERONET usadas e das fontes de areia apresentadas na tabela.

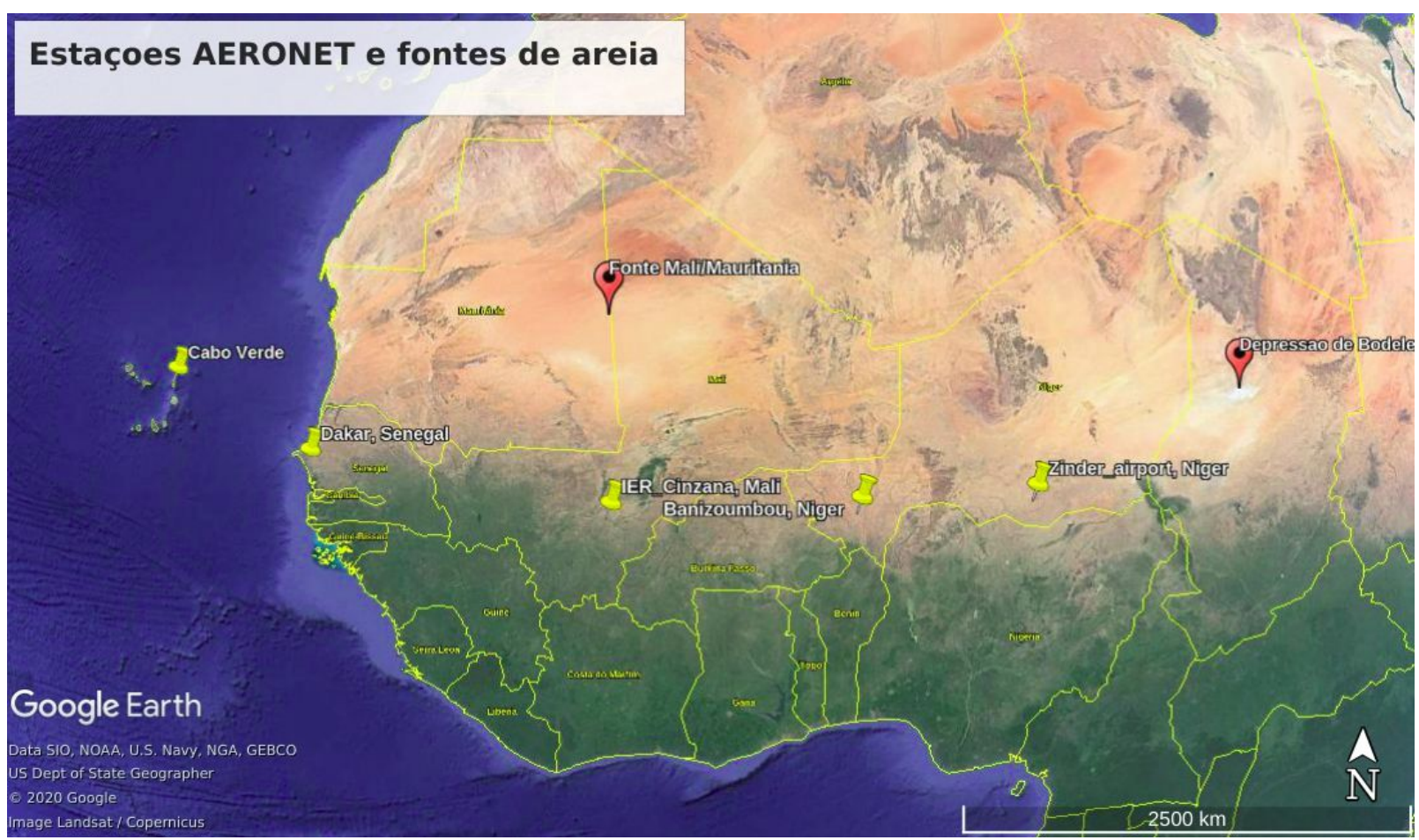

Figura 16 - Origens das plumas de aerossol e estações AERONET utilizadas neste estudo. $O$ marcador entre o norte de Mali e da Mauritânia representa uma posição aproximada de toda uma região de onde a areia se origina.

Algo que chama atenção inicialmente é a distância entre as fontes. A fonte Mali/Mauritânia está a aproximadamente $1000 \mathrm{~km}$ da costa da África, enquanto que a depressão de Bodelé está a pouco menos de 4000 km. Observa-se também a diferença latitudinal entre elas: enquanto que a fonte no norte de Mali encontra-se por volta de $22^{\circ}$ norte, a depressão de Bodelé encontra-se em $15^{\circ}$ norte. Além disso, o principal padrão atmosférico associado à emissão de areia do norte do Chade, o jato de baixos níveis de Bodelé, é um sistema de ventos de nordeste (Washington \& Todd, 2005), o que desloca as plumas inicialmente para latitudes ainda menores. Este foi um dos padrões observados para a identificação da origem das plumas. As plumas originárias de Bodelé tinham tendência a deixarem a costa africana mais ao sul em relação às plumas originárias da outra fonte. Nas figuras 17 e 18 é possível identificar essa diferença latitudinal entre as plumas de cada origem. A ausência de 
valores de $A O D$ nas figuras ocorre devido à presença de nuvens ou ao limite de varredura diária do satélite.

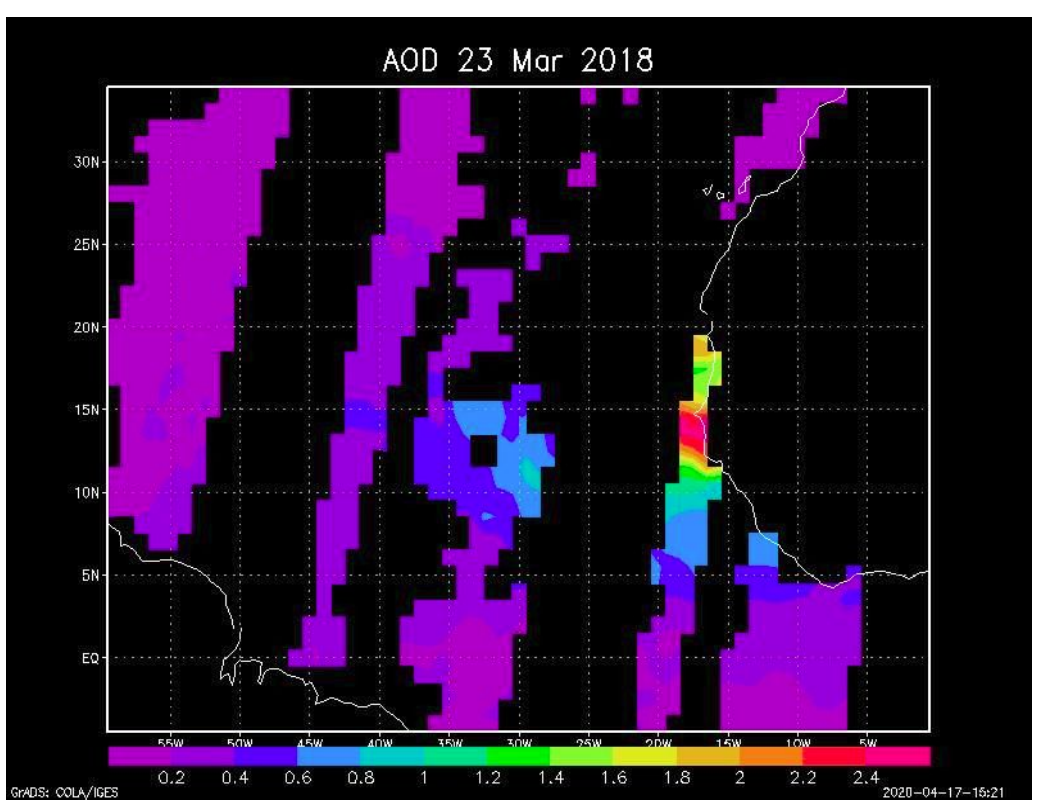

Figura 17 - AOD em 23 de março de 2018, mostrando pluma de aerossóis originária do norte de Mali deixando o continente com núcleo (valores mais elevados) por volta de $15^{\circ}$ norte.

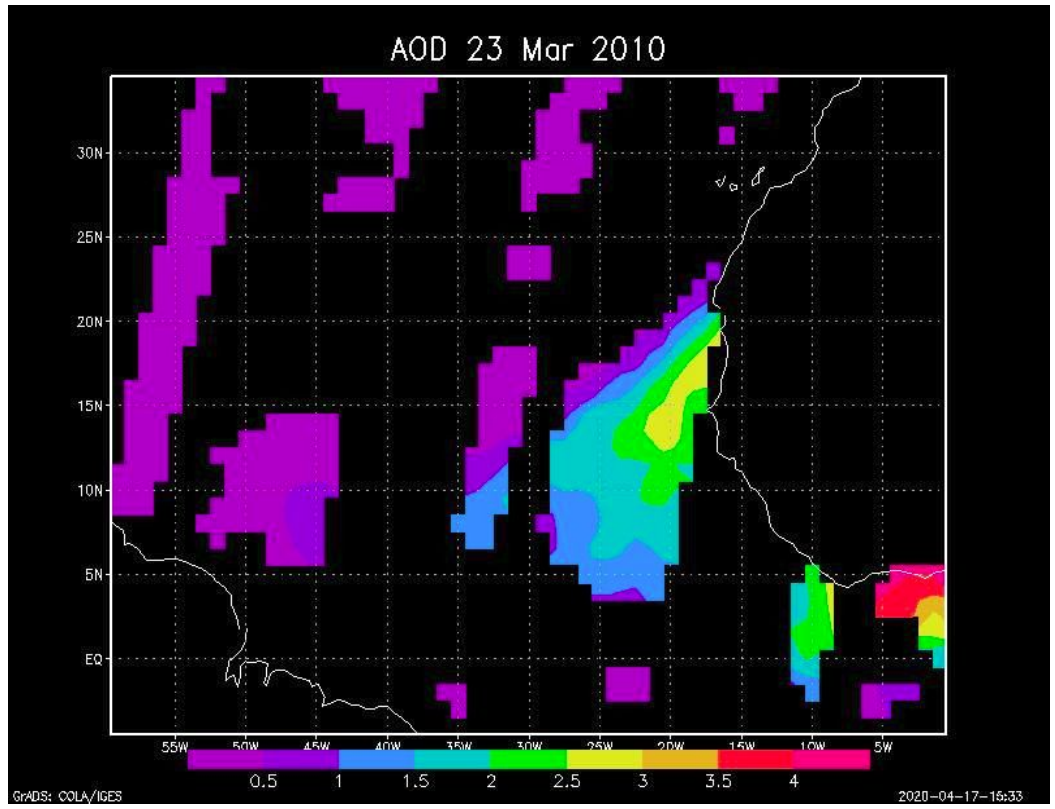

Figura 18 - AOD em 23 de março de 2010, mostrando pluma de aerossóis originária de Bodelé. Apesar de espalhada até latitudes mais elevadas, deixa o continente com núcleo (valores mais elevados) por volta de $5^{\circ}$ norte.

A latitude das plumas, juntamente com as informações de AOD das estações AERONET IER_Cinzana, Banizoumbou e Zinder Airport já consegue justificar a origem de boa parte dos eventos oriundos da depressão de Bodelé, e questionar 
Bodelé como a origem de todos os outros. No entanto, essa informação ainda não aponta a região entre Mali, Mauritânia e Argélia como outra fonte dos aerossóis transportados. Neste contexto, o relevo do continente africano ajuda a identificar regiões com maior possibilidade de atuarem como fonte para as plumas de aerossol deslocadas para o Atlântico Tropical.

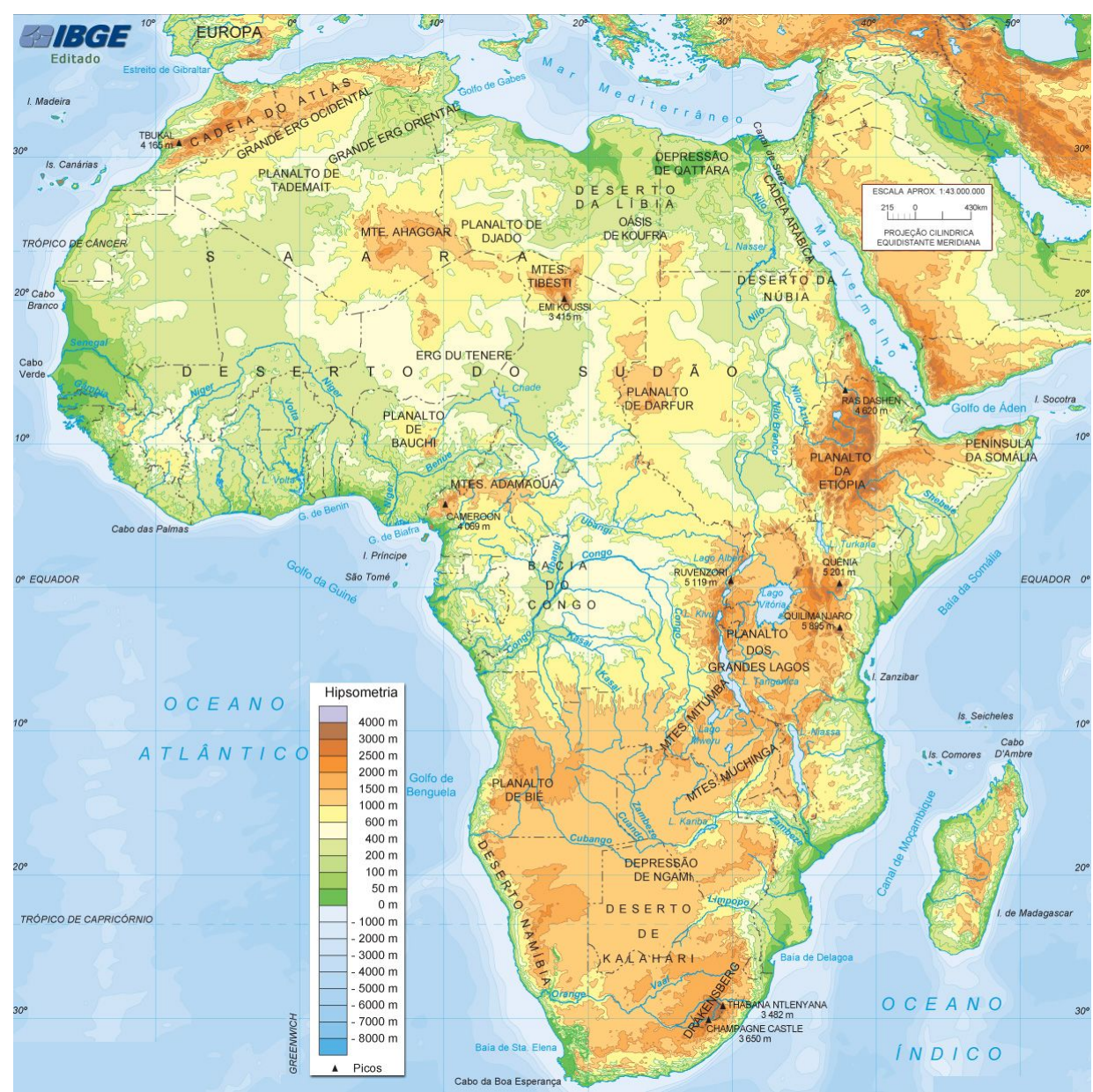

Figura 19 - Relevo africano. Fonte: IBGE.

Na região central do deserto do Saara (a noroeste da depressão de Bodelé), o relevo elevado não colabora para a ocorrência de padrões de vento que favoreçam o levantamento de aerossóis. Uma região que chama atenção nesse sentido é justamente a que compreende o norte de Mali e Mauritânia e vai até o sul da Argélia, que tem baixa elevação e é rodeada por cadeias de montanhas, assim como a depressão de Bodelé.

Simulações com o modelo Hysplit utilizando a trajetória inversa e a estação AERONET de Cabo Verde como referencial constantemente indicaram a região do 
norte de Mali e Mauritânia como origem para as massas de ar que foram para ali transportadas (figura 20).

NOAA HYSPLIT MODEL

Backward trajectory ending at 0100 UTC 27 Feb 15

GFSG Meteorological Data

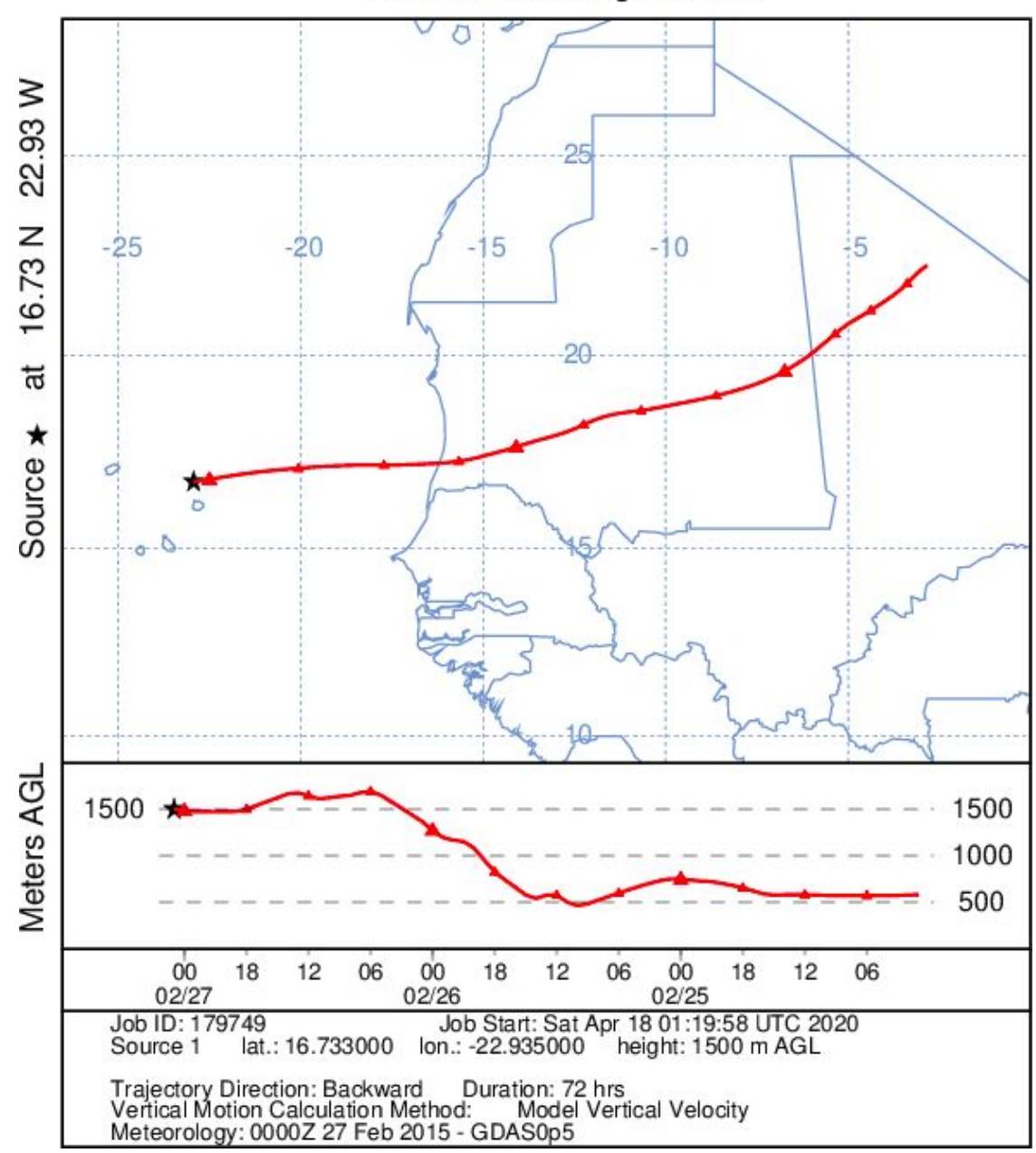

Figura 20 - Modelo de dispersão Hysplit indicando a região do norte de Mali como origem da massa de ar transportada para sobre Cabo Verde.

Os dados de entrada utilizados são do Global Data Assimilation System (GDAS), com resolução de 0,5 grau. Su et al. (2015) mostraram que as diferentes resoluções da base de dados GDAS podem gerar diferentes resultados na estimativa da trajetória. Então há de se considerar que o modelo de trajetória não pode ser utilizado isoladamente para a indicação da origem do transporte.

Em se tratando das condições meteorológicas associadas ao levantamento de areia no oeste africano, dentre os fatores apontados estão desde a ocorrência de ventos Harmatão (Oluleye \& Jimoh, 2018) até o posicionamento da alta subtropical 
(Chiapello et al., 1997). Ambos os casos implicam em características sinóticas identificáveis. Imagens no espectro visível da região que vai do norte de Mali e Mauritânia até o sul da Argélia dias antes de eventos de transporte detectados, reforçam a hipótese de sistemas sinóticos e até de mesoescala atuando na emissão de areia daquela região (figura 21).

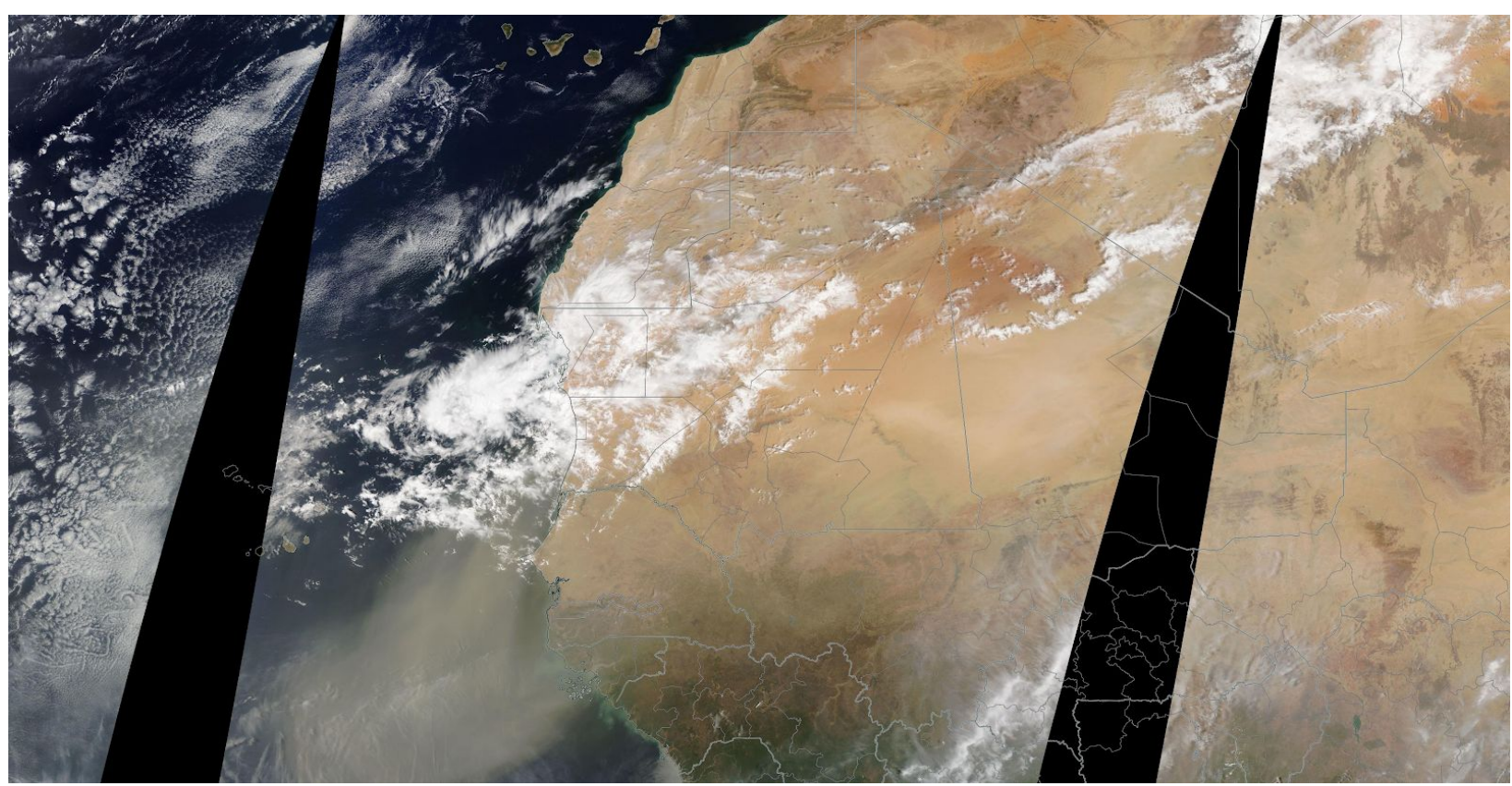

Figura 21 - Imagem no espectro visível do oeste africano em 28/03/2017. É possível identificar faixa de nuvens, além de pluma de areia deixando o continente africano. Fonte: EOSDIS NASA.

Foram observados também padrões de velocidade do vento associados a cada origem do transporte. As figuras 22 e 23 mostram a velocidade do vento em superfície referente a dois eventos, um de cada origem. Quando a origem dos aerossóis é o norte de Mali, há um núcleo com maior velocidade do vento na costa da África, acima de $20^{\circ} \mathrm{N}$. Nesses eventos a velocidade do vento esteve repetidamente acima de $10 \mathrm{~m} / \mathrm{s}$. Em eventos de transporte originados em Bodélé, mesmo que houvesse a presença de um núcleo com maior velocidade do vento na mesma região, a velocidade do vento era menor. Acredita-se que esse padrão de velocidade do vento em baixos níveis mais elevado nesta região possa estar associado principalmente ao posicionamento da alta subtropical, segundo Chiapello et al. (1997), e consequente favorecimento do levantamento de areia no norte do Mali, não descartando a possibilidade da ocorrência de outros sistemas não mencionados neste estudo. Nos eventos oriundos de Bodelé, os padrões de vento 
em baixos níveis associados ao levantamento da areia ocorrem em torno de $17^{\circ} \mathrm{E} e$ $17^{\circ} \mathrm{N}$ dias antes das plumas deixarem a costa africana. Na figura 22 é possível identificar nessa região um núcleo com velocidade do vento elevada dois dias antes das plumas começarem a ser identificadas deixando o continente.

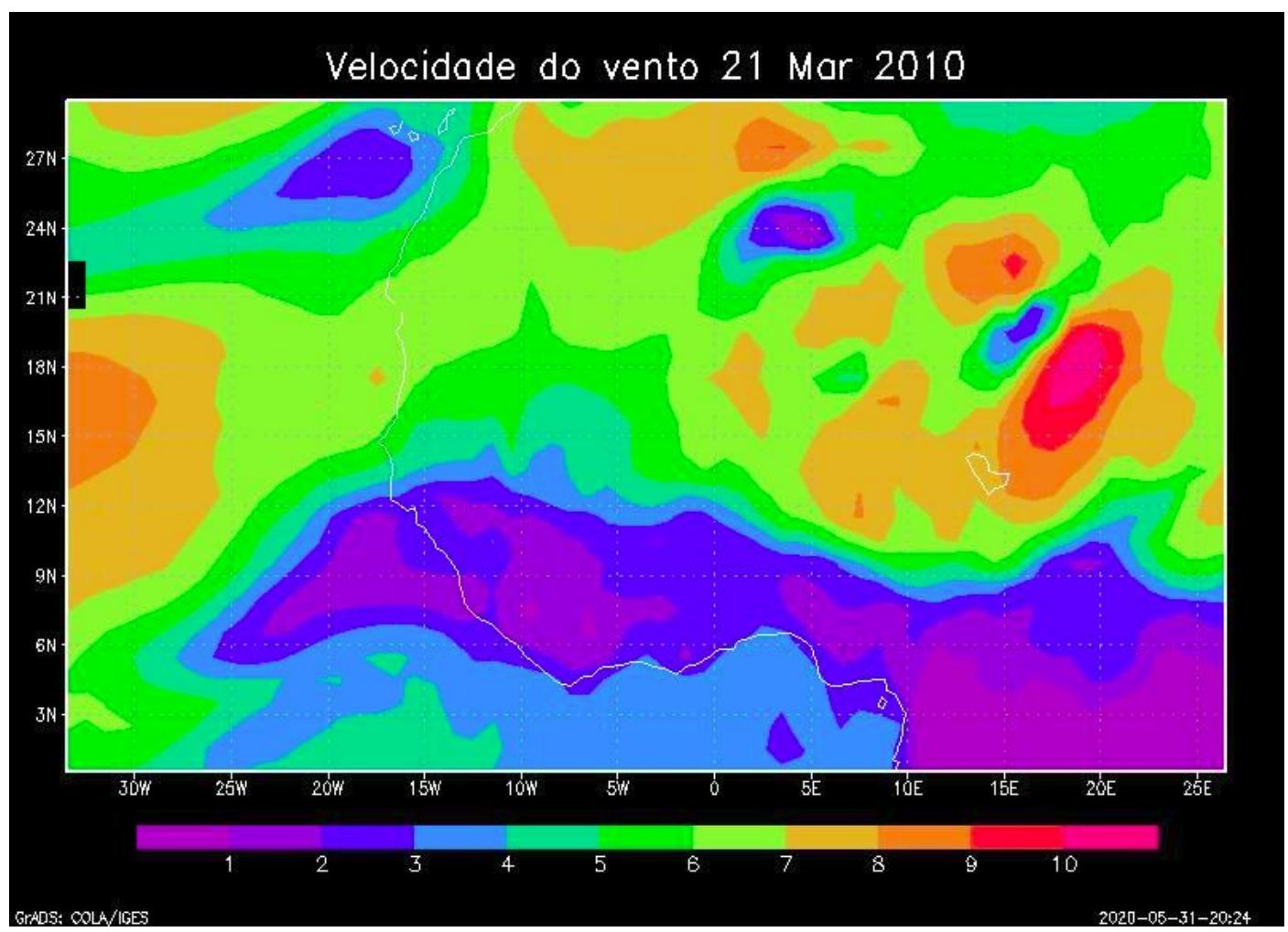

Figura 22 - Velocidade do vento em superfície em 21/3/2010, mostrando velocidade do vento elevada na região de origem dos aerossóis (na depressão de Bodelé). 


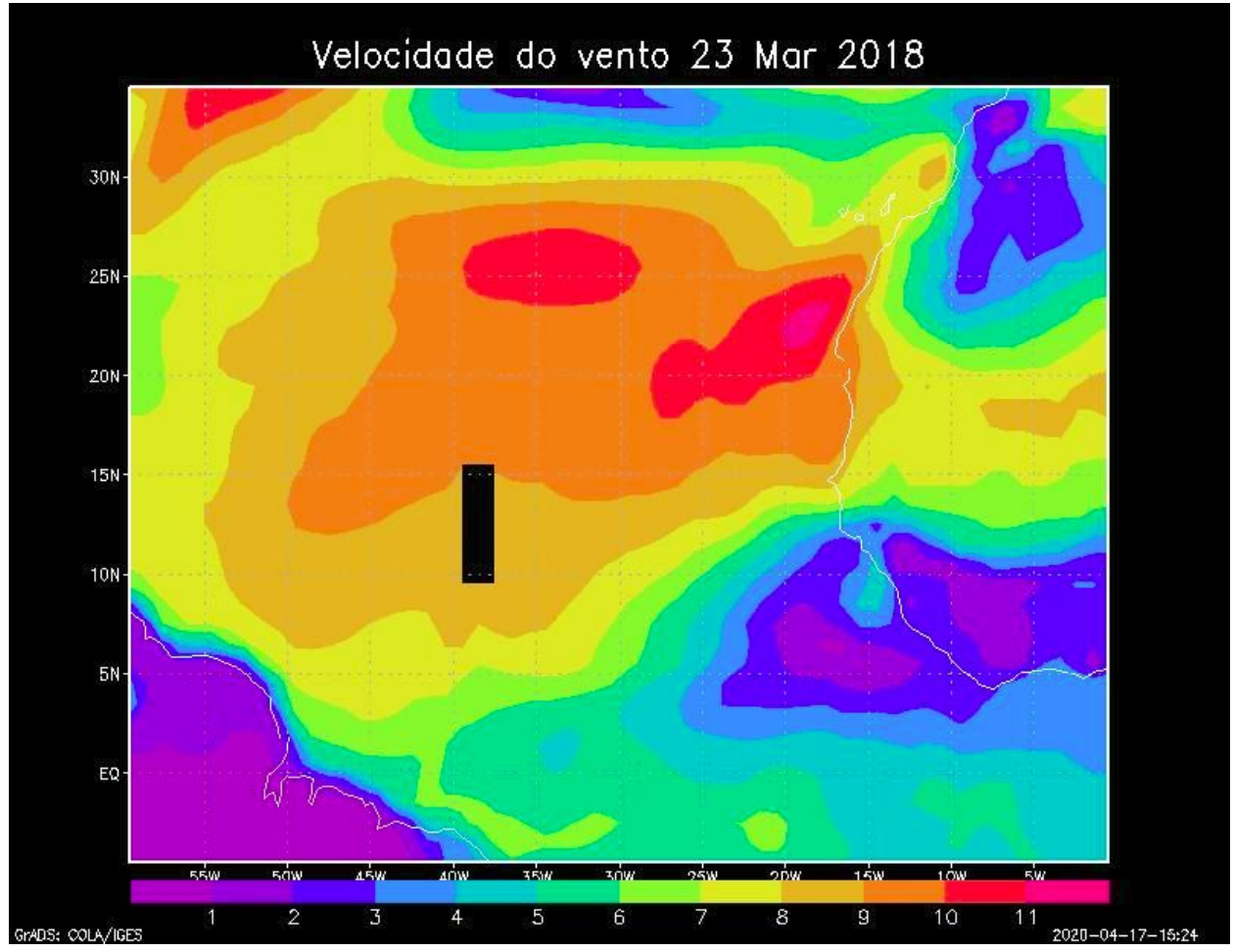

Figura 23 - Velocidade do vento em superfície em 23/03/2018, evento de transporte com origem no norte de Mali. Destaque para a região com velocidade do vento acima de $11 \mathrm{~m} / \mathrm{s}$.

Todas as informações aqui apresentadas foram reunidas com a intenção de determinar a origem dos aerossóis, apresentada na tabela 1. Em dois eventos haviam indícios da emissão de aerossóis por ambas as fontes, então elas foram classificadas como indefinidas e não foram usadas para as análises do forçamento radiativo de nenhuma das origens. A figura 24 mostra a quantidade dos eventos originados em cada origem dentre os 40 utilizados neste estudo. 


\section{Origem da areia nos eventos analisados}

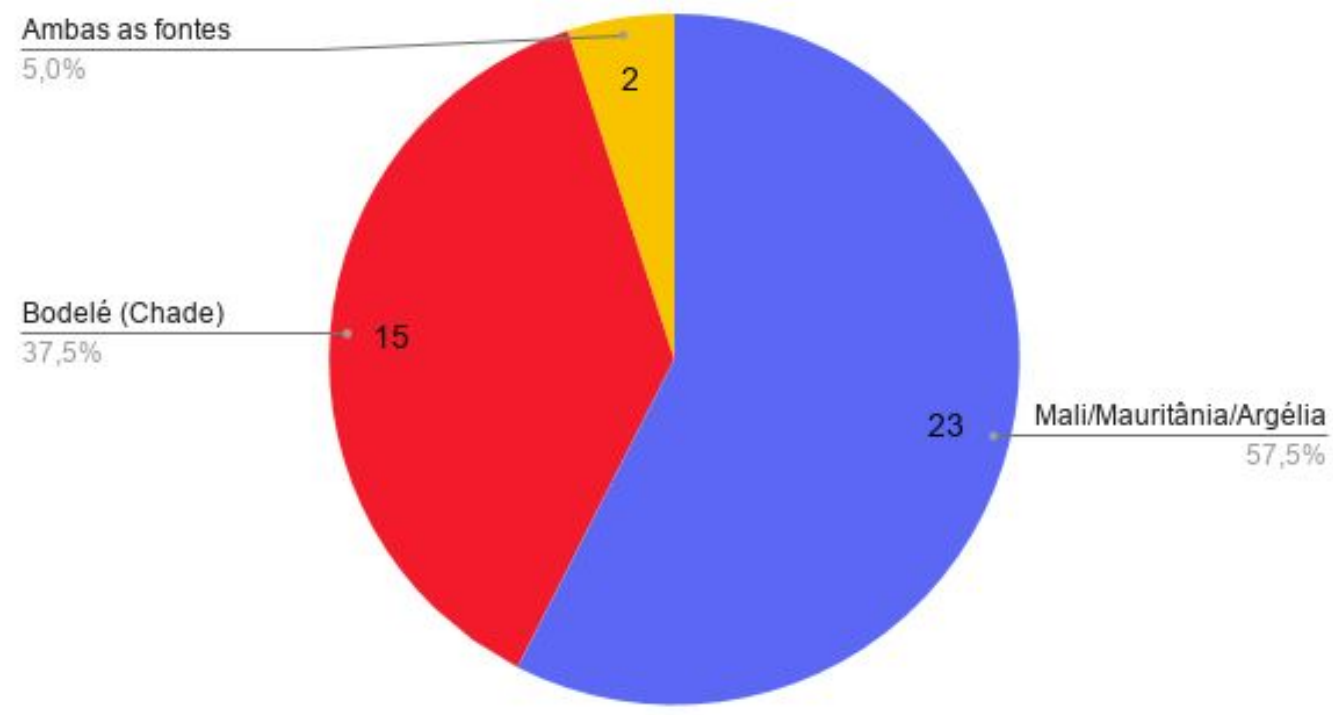

Figura 24 - Origem dos aerossóis nos 40 eventos utilizados neste estudo.

Um fato de destaque é a maior ocorrência de eventos originados no norte de Mali e Mauritânia e sul da Argélia. Porém é importante ressaltar que a metodologia utilizada buscou encontrar os eventos mais intensos utilizando dados sobre o oceano logo após as plumas deixarem o continente africano. Nesse contexto, a proximidade da fonte do norte de Mali em relação à costa africana pode favorecer a intensidade dos eventos de transporte nessa região. Entretanto, a sustentação das plumas de aerossol para transportes a distâncias maiores, como a Amazônia, pode passar pelos padrões sinóticos e de mesoescala associados à origem, bem como as propriedades dos aerossóis. Sistemas atuantes na origem do transporte, como o jato de baixos níveis de Bodelé, são determinantes à quantidade de areia que será levantada, e um evento com maior quantidade de areia transportada tem mais chances de ter maior duração. Nas fases seguintes do transporte, fenômenos como correntes descendentes, formação de nuvens ou até mesmo chuva podem agir na desestruturação das plumas e na deposição destes aerossóis, e estes fatores independem da origem. Além dos aspectos mencionados, a distribuição de tamanho das partículas é outro fator determinante à eficiência do transporte a longas distâncias, uma vez que partículas maiores tendem a ser mais efetivamente depositadas pela ação da gravidade. 
Koren et al. (2006) apontaram a depressão de Bodelé como principal fonte de aerossóis do deserto do Saara transportados para a Amazônia. O que foi observado quanto à origem dos eventos que chegaram à Amazônia (figura 25), dentro da amostragem de 40 eventos analisados neste estudo, está de acordo com este resultado. Os resultados apresentados contabilizam todas as plumas que ainda podiam ser detectadas através da AOD em longitudes a oeste de $40^{\circ} \mathrm{W}$ e a sul de $6,5^{\circ} \mathrm{N}$, ou seja, não foram dissipadas até alcançarem a costa da América do Sul.

\section{Origem da areia nos casos que chegaram até a Amazônia}

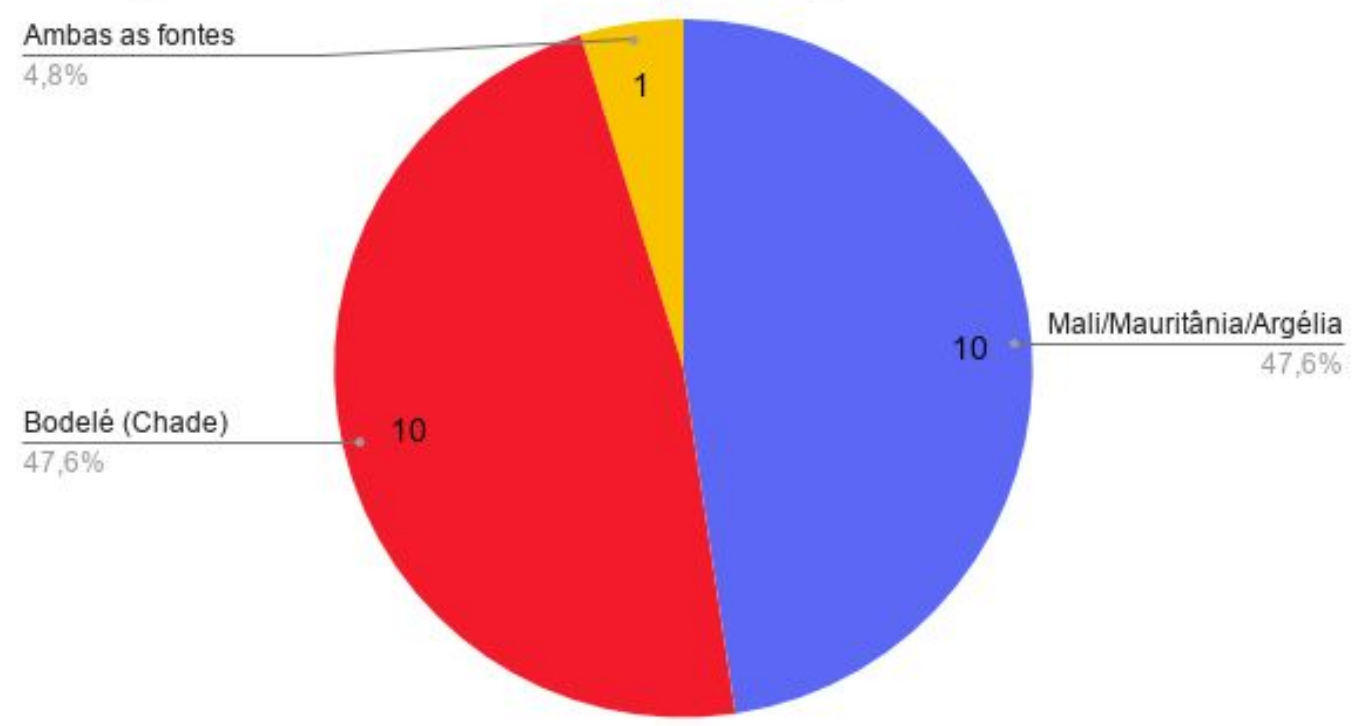

Figura 25 - Origem da areia nos eventos em que as plumas chegaram até a Amazônia.

Apesar de, neste estudo, os eventos originários do norte de Mali representarem $20 \%$ a mais dos que foram originados em Bodelé (como mostrado na figura 24), as duas origens representam a mesma quantidade de eventos que chegaram à Amazônia. Isso indica que, dentro da amostragem analisada neste estudo, o transporte de aerossóis do norte do Chade foi mais eficiente em transportes para longas distâncias, como para a Amazônia. Este estudo não buscou as causas desse fenômeno, porém estas podem estar relacionadas a padrões atmosféricos associados a cada origem e às características de cada aerossol, como já discutido nesta seção. 


\subsection{Forçamento Radiativo e Eficiência de Forçamento Radiativo Instantâneos de Aerossol}

Para identificação dos impactos radiativos das plumas de aerossol, os eventos foram separados de acordo com a sua origem (Bodelé ou Mali). O FRA e a ef aqui calculados são instantâneos, do momento das observações, logo, trazem consigo a dependência do ângulo zenital solar. Essa dependência é minimizada quando calculada a eficiência diária. As figuras 26 a 29 mostram o forçamento radiativo médio em cada etapa do transporte, para o espectro solar e o terrestre, no TOA, atmosfera (atm) e superfície (sfc), juntamente com a AOD média, baseado em medidas dos satélites Aqua e Terra. São valores médios para todos os casos identificados, para qualquer valor de ângulo zenital solar. É comum a inexistência de dados do saldo de radiação em superfície (que é resultado de modelagem numérica) apesar da existência de dados de fluxos no TOA. Essa escassez de dados em superfície pode ser vista nos gráficos pela falta de alguns valores FRA instantâneo médio em superfície e na atmosfera na etapa 3. As barras de erro mostram o desvio padrão de cada cenário.

\section{Forçamento Radiativo Instantâneo Médio (Aqua) - Aerossóis de Bodelé}

SWTOA (Aqua) SW ATM (Aqua) SW SFC (Aqua) LWTOA (Aqua)

LW ATM (Aqua) LWSFC (Aqua) AOD (Aqua)

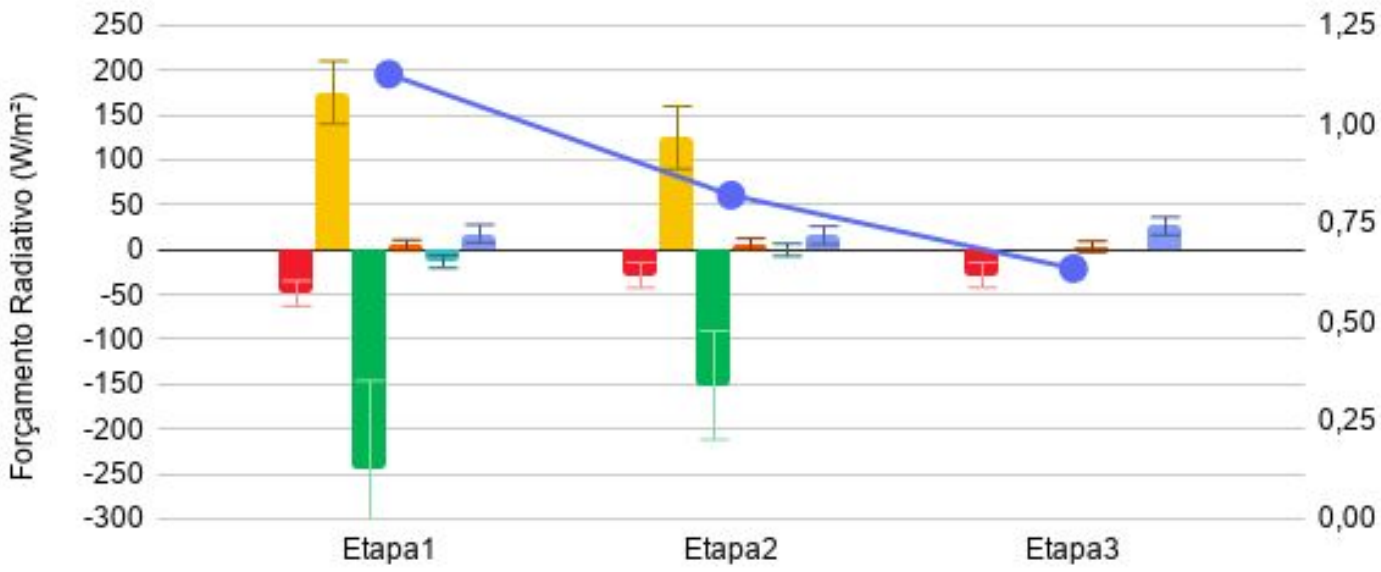

Figura 26 - Forçamento Radiativo Instantâneo Médio para o aerossol originário da região de Bodelé, estimado a partir das passagens do satélite Aqua. 


\section{Forçamento Radiativo Instantâneo Médio (Terra) - Aerossóis de Bodelé}

SW TOA (Terra) SW ATM (Terra) SW SFC (Terra) LW TOA (Terra)

LW ATM (Terra) LW SFC (Terra) AOD (Terra)

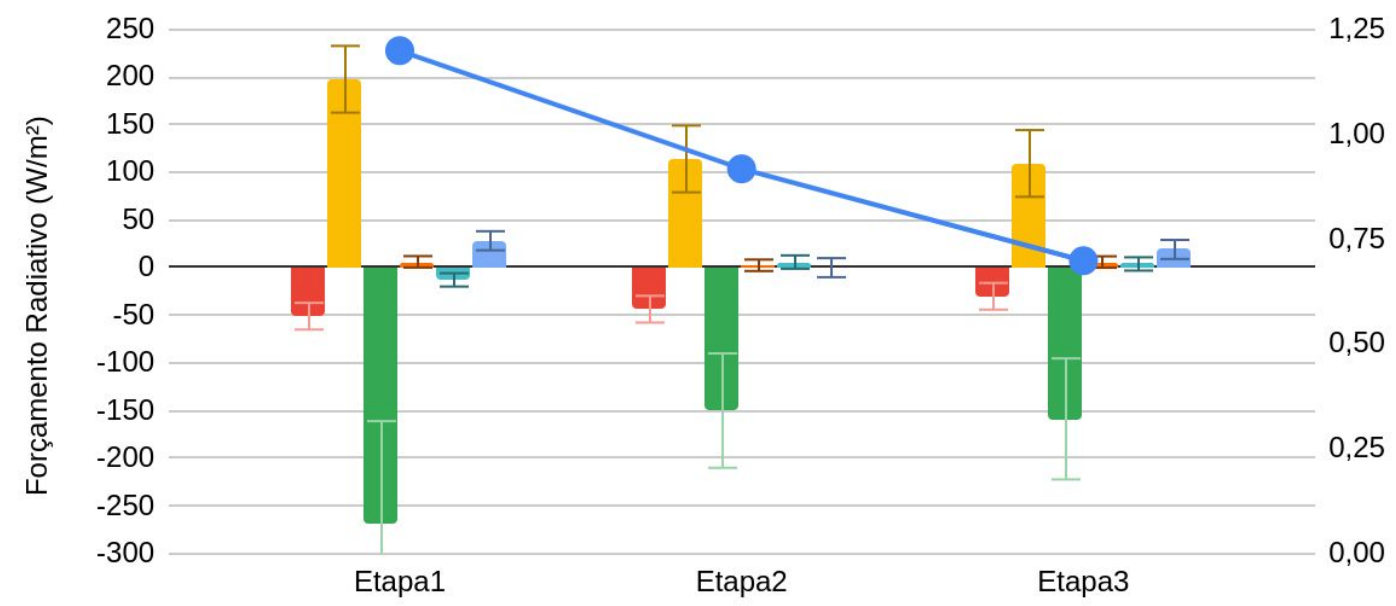

Figura 27 - Forçamento Radiativo Instantâneo Médio para o aerossol originário da região de Bodelé, estimado a partir das passagens do satélite Terra.

\section{Forçamento Radiativo Instantâneo Médio (Aqua) - Aerossóis de Mali}

SW TOA (Aqua) SW ATM (Aqua) SW SFC (Aqua) $\square$ LW TOA (Aqua)

$$
\operatorname{LW} \operatorname{ATM}(\text { Aqua) LW SFC (Aqua) AOD (Aqua) }
$$

150

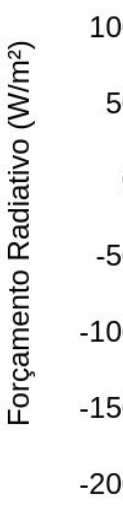

$-200$

Figura 28 - Forçamento Radiativo Instantâneo Médio para o aerossol originário da região do norte de Mali, estimado a partir das passagens do satélite Aqua. 


\section{Forçamento Radiativo Instantâneo Médio (Terra) - Aerossóis de Mali}

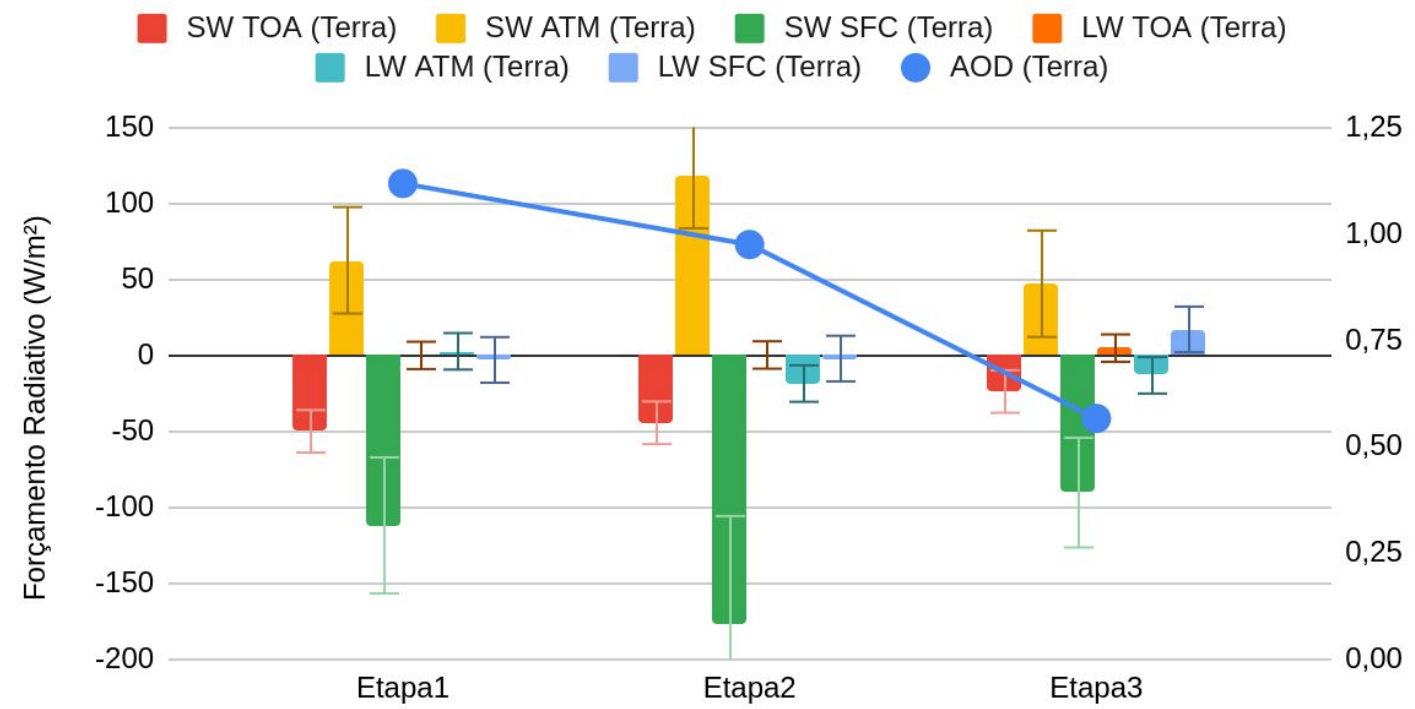

Figura 29 - Forçamento Radiativo Instantâneo Médio para o aerossol originário da região do norte de Mali, estimado a partir das passagens do satélite Terra.

Um dos primeiros fatores a chamar atenção nos valores médios é o elevado valor (em módulo) do forçamento radiativo em superfície no espectro solar. Fica claro aqui que essa é a camada e região do espectro mais impactada do ponto de vista radiativo. Isso pode ser justificado por três principais fatores: o albedo simples, padrão de espalhamento e estrutura das camadas de aerossol. Como já mencionado, o albedo simples dos aerossóis originados no deserto é, em geral, bastante elevado ( 0,93, chegando a $\sim 0,99$ no infravermelho próximo), o que significa que estes aerossóis têm elevada capacidade de espalhamento de radiação. O padrão de espalhamento desse tipo de aerossol, como também já mencionado, é preferencialmente frontal. Seguindo essas informações, o natural seria grande espalhamento frontal da irradiância solar descendente, resultando num forçamento radiativo baixo. Entretanto, baseado na estrutura vertical das plumas descrito por Liu et al. (2012) e também observada em alguns eventos utilizando dados do CALIOP (figura 30), é possível afirmar que as plumas têm, em geral, de 2 a $4 \mathrm{~km}$ de espessura. Essa estrutura vertical juntamente com dimensão horizontal da ordem de centenas de milhares de $\mathrm{km}$, permite que um feixe de radiação solar interaja inúmeras vezes com aerossóis no seu caminho, fazendo da absorção e do 
retroespalhamento fatores de maior representatividade do que seriam caso a espessura da camada de aerossóis fosse menor.

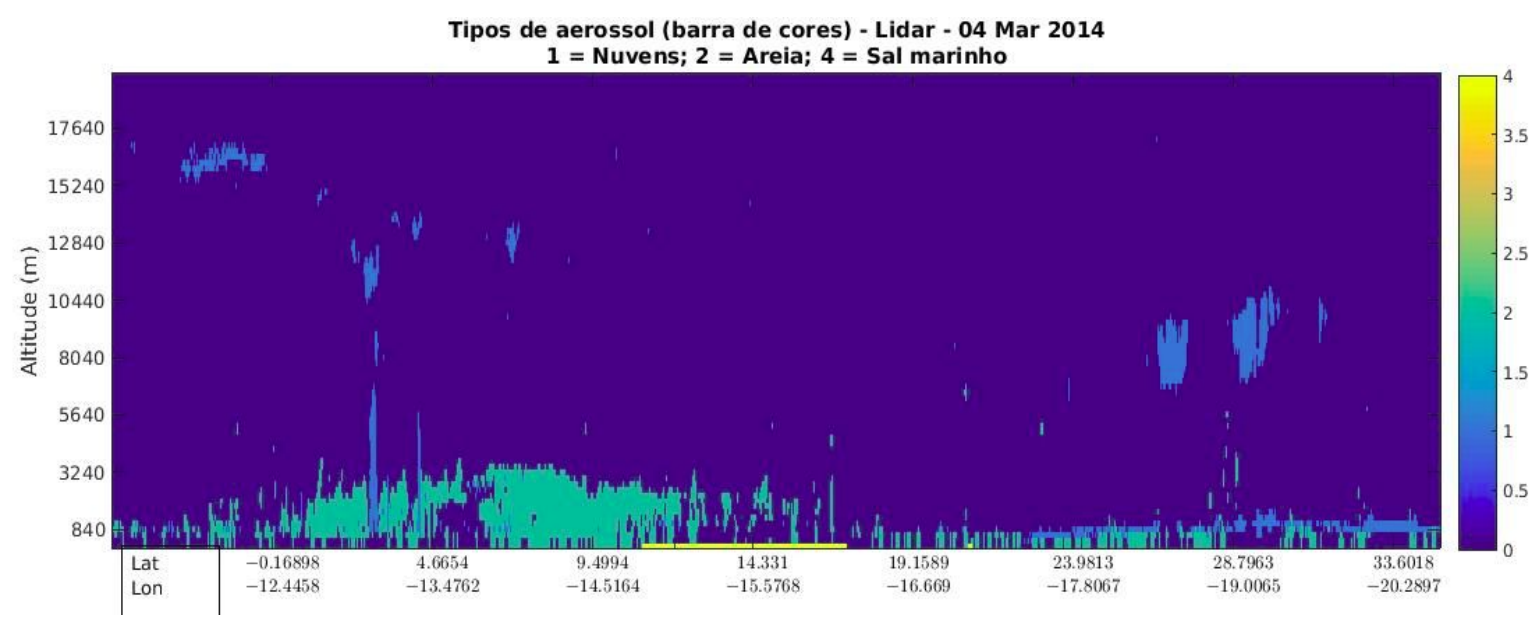

Figura 30 - Estrutura vertical da pluma de aerossóis num evento de transporte em 04/03/2014 (produzido com o Aerosol Mask a partir da passagem do satélite CALIPSO). Note a pluma de areia alcançando altitude de aproximadamente 3500 metros.

A hipótese aqui levantada, então, é de que, ao interagir com as plumas de aerossol, a irradiância solar descendente que não é transmitida para a superfície: 1) é absorvida pelos aerossóis; 2) é retroespalhada e acaba sendo absorvida por componentes atmosféricos em níveis entre as plumas e o TOA; ou 3) é retroespalhada e chega ao TOA. Baseado no forçamento radiativo no espectro solar no TOA, percebe-se que 3) representa uma menor porção do total da radiação que deixou de chegar em superfície, logo 1) e 2) são os principais fatores que justificam o maior forçamento radiativo em superfície, do que no TOA ou na atmosfera. Esses processos também justificam o comportamento qualitativo apresentado, com forçamento positivo na atmosfera, e negativo em superfície e no TOA para a radiação solar.

Outro fator que chama atenção no FRA é a diferença entre os valores no espectro solar e no espectro terrestre, com o último tendo valores muito menores em módulo. O albedo simples da areia aumenta e o parâmetro de tamanho diminui com o distanciamento do espectro visível sentido infravermelho. Por esse motivo, a absorção de radiação pelos aerossóis, que já não era um fator de destaque no espectro solar, perde ainda mais importância, enquanto que o espalhamento se aproxima do padrão simétrico. Esses são fatores que contribuem para o baixo 
impacto radiativo da areia no espectro terrestre. No espectro terrestre não é possível identificar padrões diretamente associados apenas à presença do aerossol, o que indica que outros atores não investigados neste estudo (como o vapor d'água, por exemplo) podem ter um impacto muito maior no balanço de onda longa.

Para visualizar a diferença entre o forçamento radiativo de aerossol no espectro solar e no espectro terrestre, foi calculada para os aerossóis de ambas as origens, uma fração $F(\mathrm{Iw})$, que é resultado da divisão do FRA no TOA, no espectro terrestre, de cada pixel, pelo seu respectivo forçamento no espectro solar. As figuras 31 e 32 mostram a distribuição do valor de $F(I w)$.

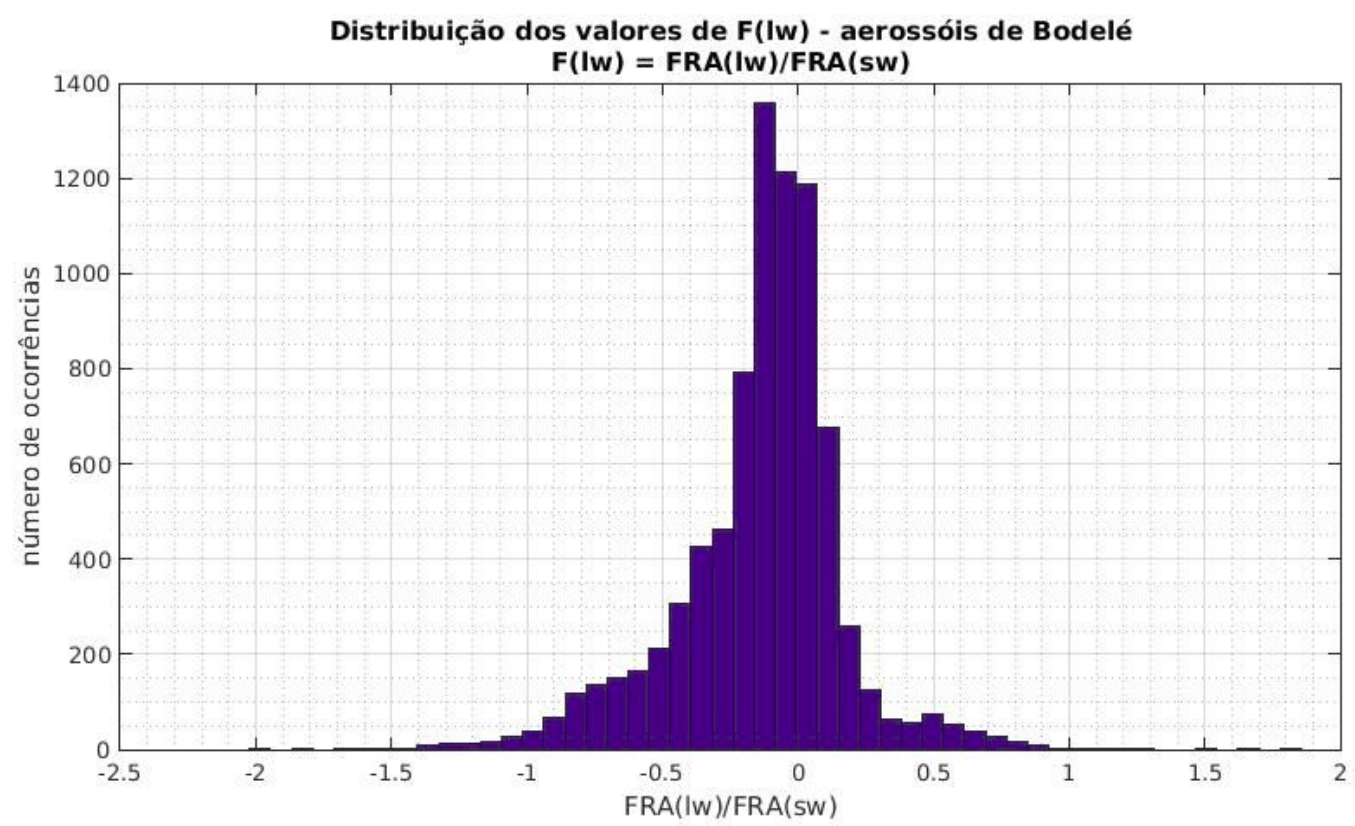

Figura 31 - Distribuição dos valores de $\mathrm{F}(\mathrm{Iw})$, que é resultado da divisão do FRA no espectro terrestre pelo FRA no espectro solar, no TOA, para um mesmo pixel, em eventos originários de Bodelé. 


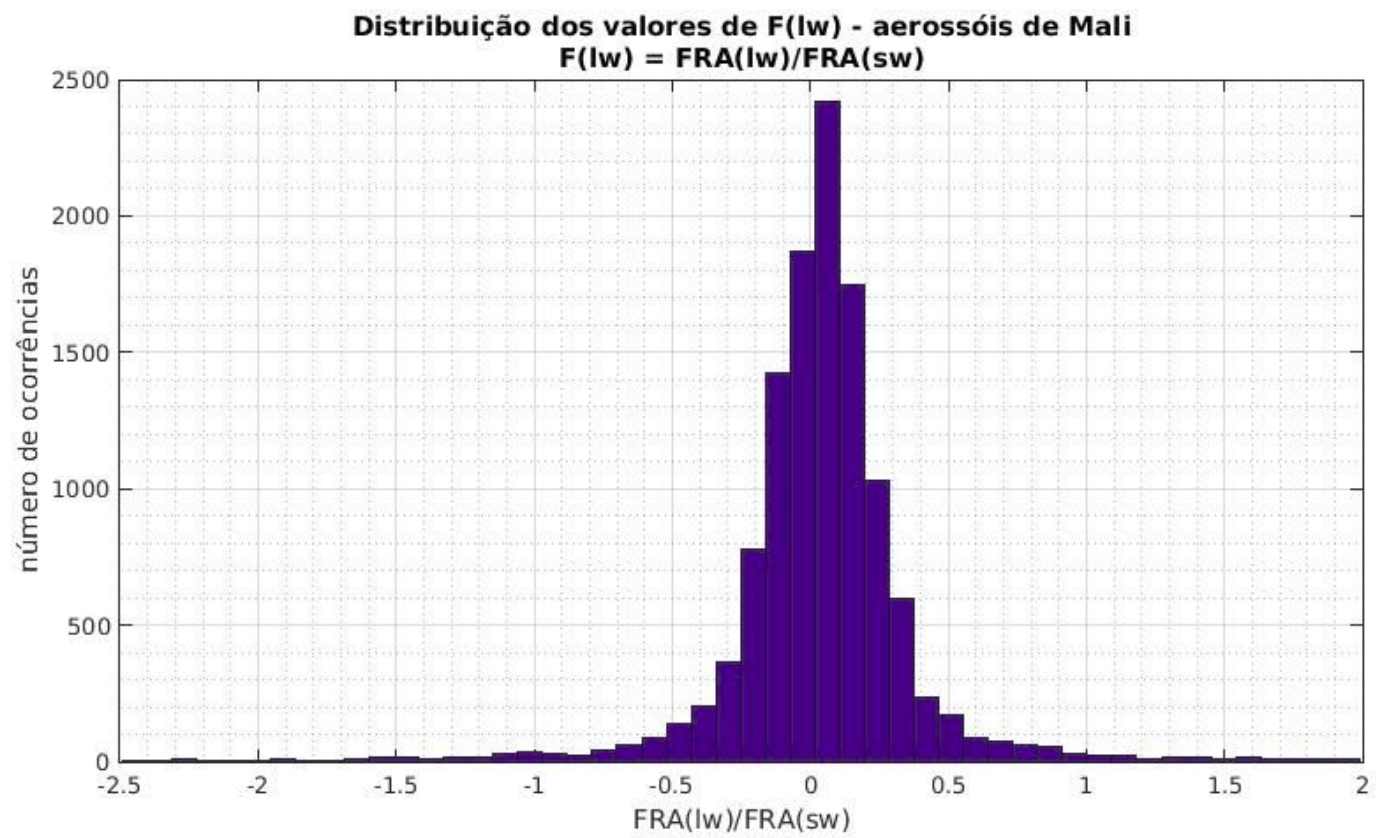

Figura 32 - Distribuição dos valores de $F(I w)$, que é resultado da divisão do FRA no espectro terrestre pelo FRA no espectro solar, no TOA, para um mesmo pixel, em eventos originários de Mali.

A distribuição dos valores da fração $F(\mathrm{Iw})$ em ambos os casos se concentra em torno de 0 , com médias de -0,1358 e 0,0349, indicando que o forçamento radiativo de aerossol no espectro terrestre representa, em módulo, 13\% e $3 \%$ do total para o espectro solar na média, em eventos com aerossóis de Bodelé e de Mali respectivamente. Os pixels com valores elevados, em módulo, da fração $F(\mathrm{Iw})$, especialmente os que têm valor acima de 1, são resultado de valores de FRA(sw) próximos de 0 , não tendo relação com qualquer comportamento do FRA(Iw).

Devido aos resultados indicarem um impacto pouco representativo no espectro terrestre, a análise mais detalhada que se segue é focada no impacto da areia sobre o fluxo de radiação no espectro solar. Dentre os fluxos de onda curta, é dado destaque aos resultados no TOA, como já justificado, por este apresentar resultados observacionais, onde fica mais claro o efeito do aerossol, em detrimento de efeitos causados por outros componentes na atmosfera.

$O$ efeito do aerossol, neste contexto, é avaliado pela relação entre o FRA e a AOD. O que é observado é uma relação clara entre a profundidade óptica de aerossol e seu forçamento radiativo, no qual o forçamento aumenta (em módulo) com o aumento da AOD. A passagem do satélite Terra ocorre no final da manhã, enquanto que do satélite Aqua ocorre próximo ao meio da tarde, por esse motivo 
eles são analisados separadamente quanto às observações instantâneas (porém são utilizados em conjunto no cálculo de variáveis diárias. As figuras 33 a 38 mostram a relação AOD x FRA para os aerossóis de ambas as origens identificadas, para os dados de cada satélite, nas três etapas do transporte entre a África e a América do Sul.

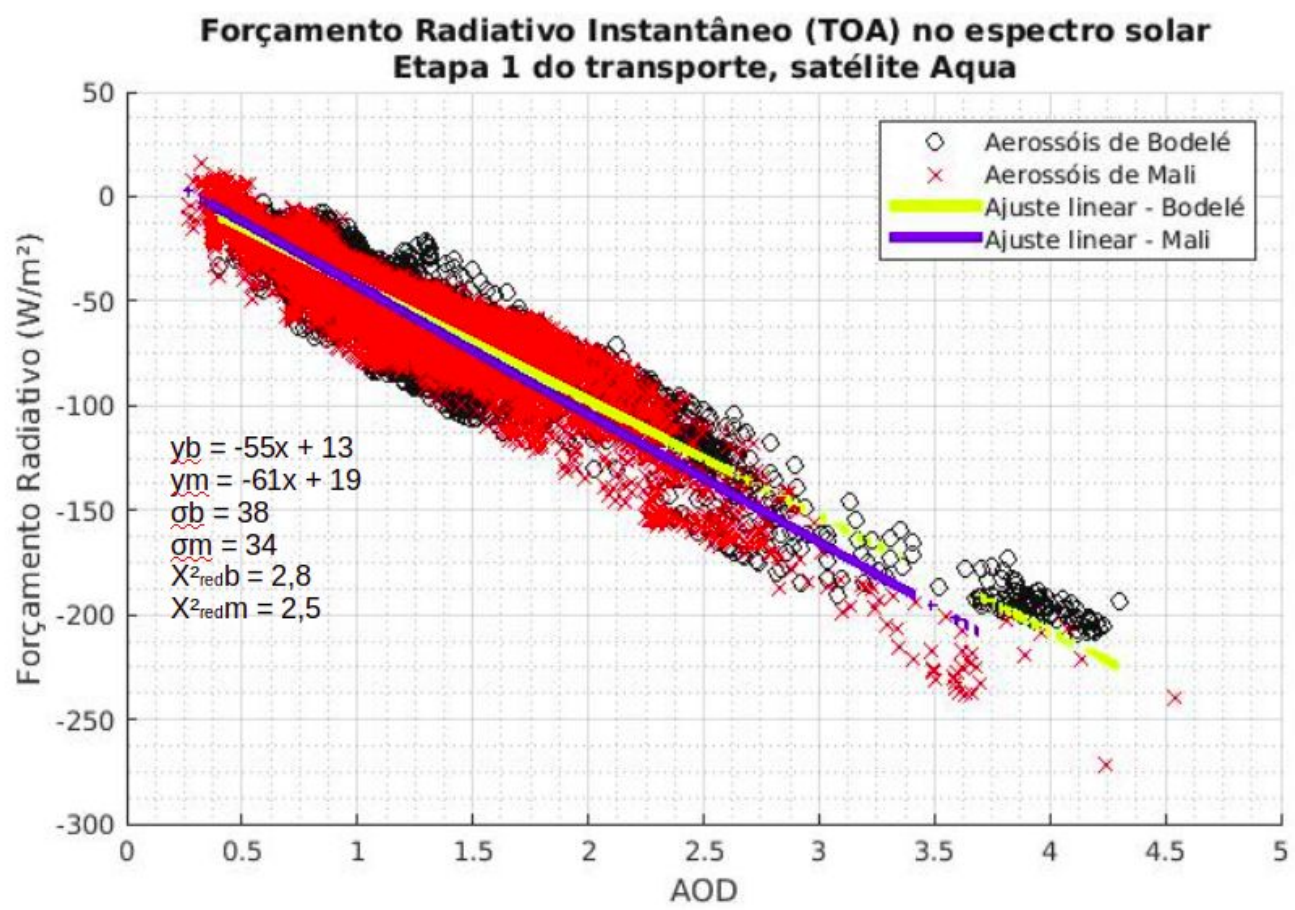

Figura 33 - Relação AOD (em 550 nm) x FRA instantâneo no espectro solar no TOA na etapa 1, estimados pelo satélite Aqua. Letra $\mathrm{b}$ ou $\mathrm{m}$ após parâmetros estatísticos indica Bodelé ou Mali. Incertezas (S) dos parâmetros a e $b$ da regressão linear: $S_{a b}=0,22 ; S_{b b}=0,27 ; S_{a m}=0,19 ; S_{b m}=0,22$. 


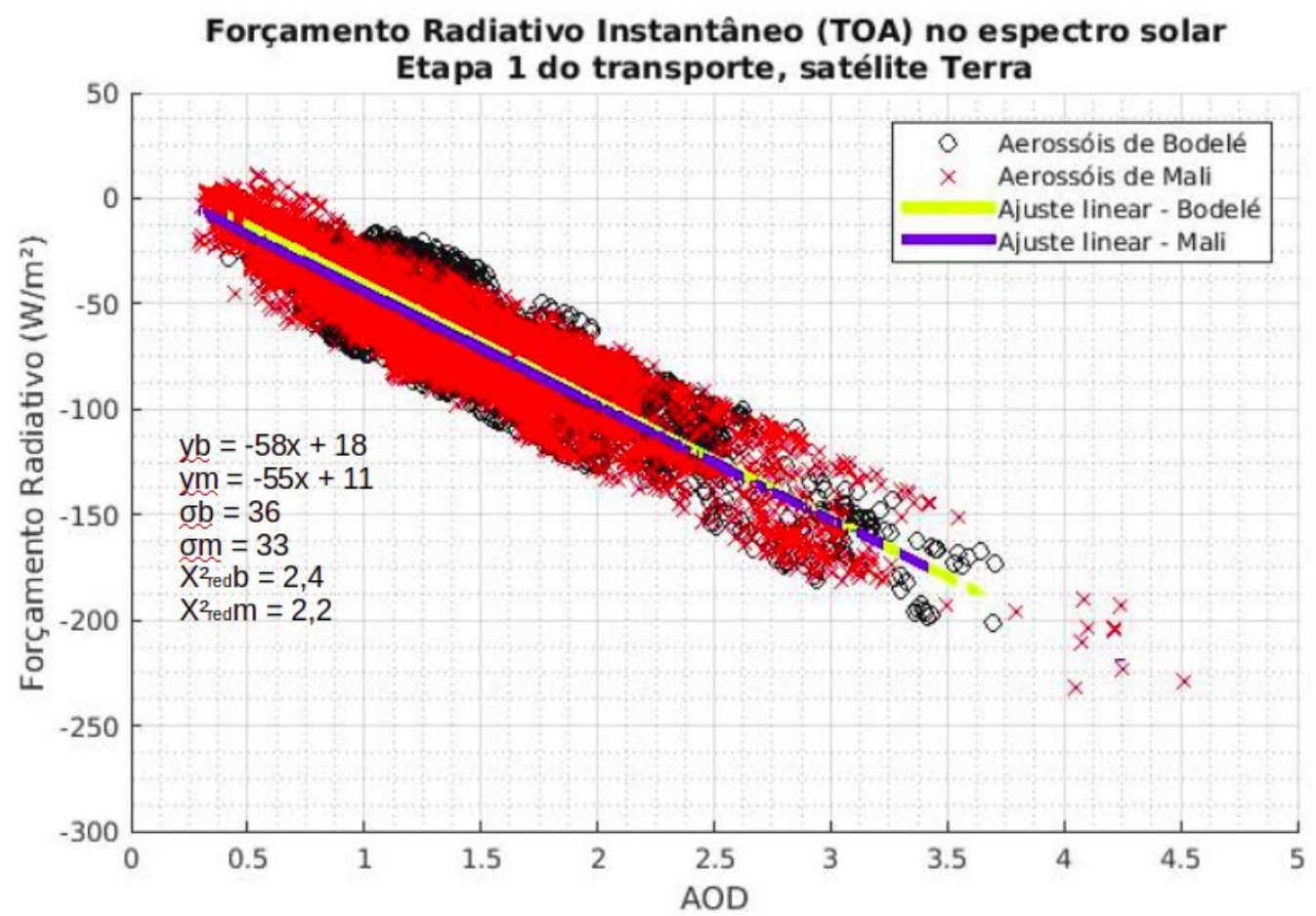

Figura 34 - Relação AOD (em 550 nm) x FRA instantâneo no espectro solar no TOA na etapa 1, estimados pelo satélite Terra. Letra $b$ ou $\mathrm{m}$ após parâmetros estatísticos indica Bodelé ou Mali. Incertezas (S) dos parâmetros a e $b$ da regressão linear: $S_{a b}=0,23 ; S_{b b}=0,31 ; S_{a m}=0,18 ; S_{b m}=0,22$.

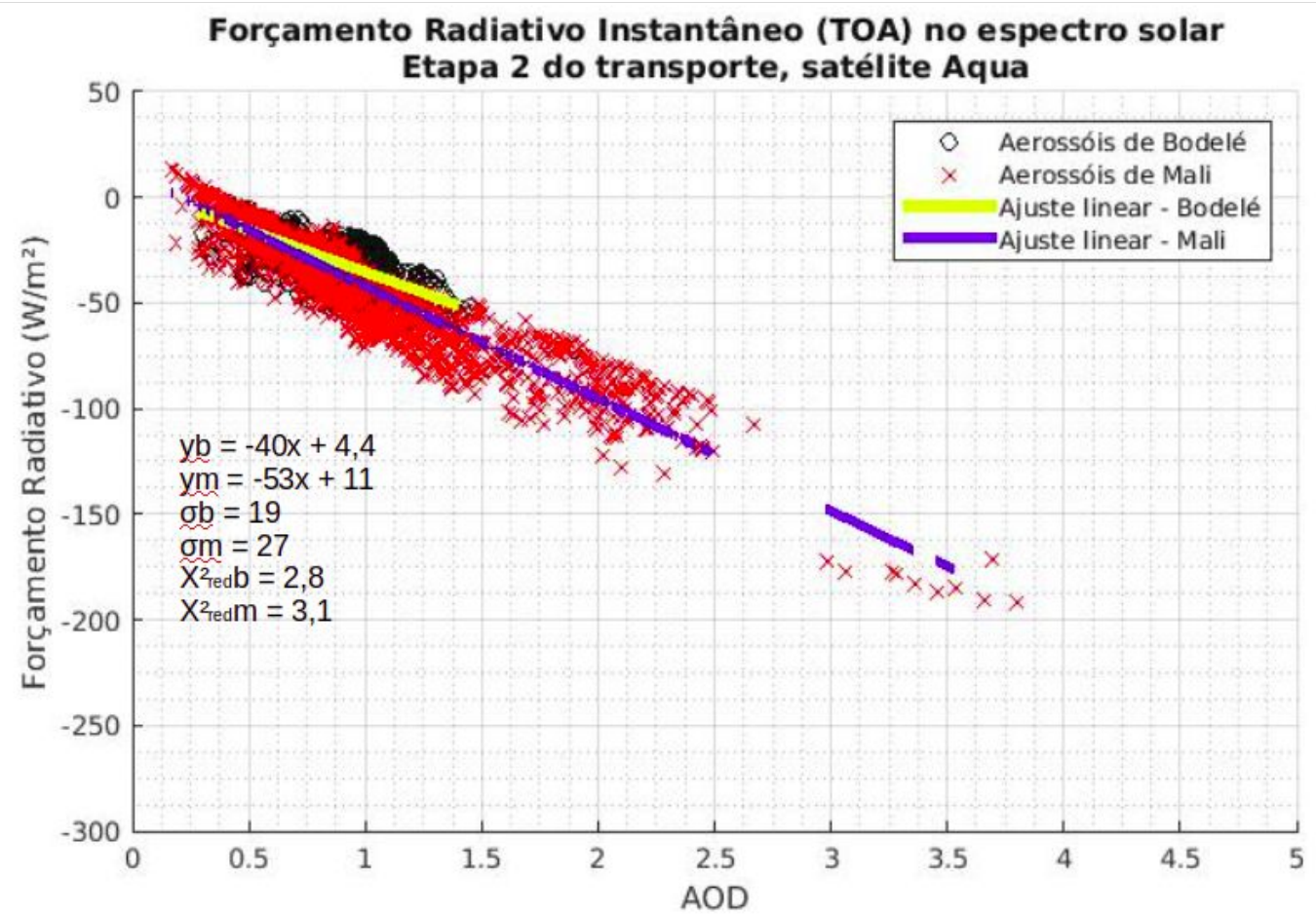

Figura 35 - Relação AOD (em 550 nm) x FRA instantâneo no espectro solar no TOA na etapa 2, estimados pelo satélite Aqua. Letra b ou $\mathrm{m}$ após parâmetros estatísticos indica Bodelé ou Mali. Incertezas (S) dos parâmetros a e $b$ da regressão linear: $S_{a b}=0,80 ; S_{b b}=0,66 ; S_{a m}=0,29 ; S_{b m}=0,28$. 


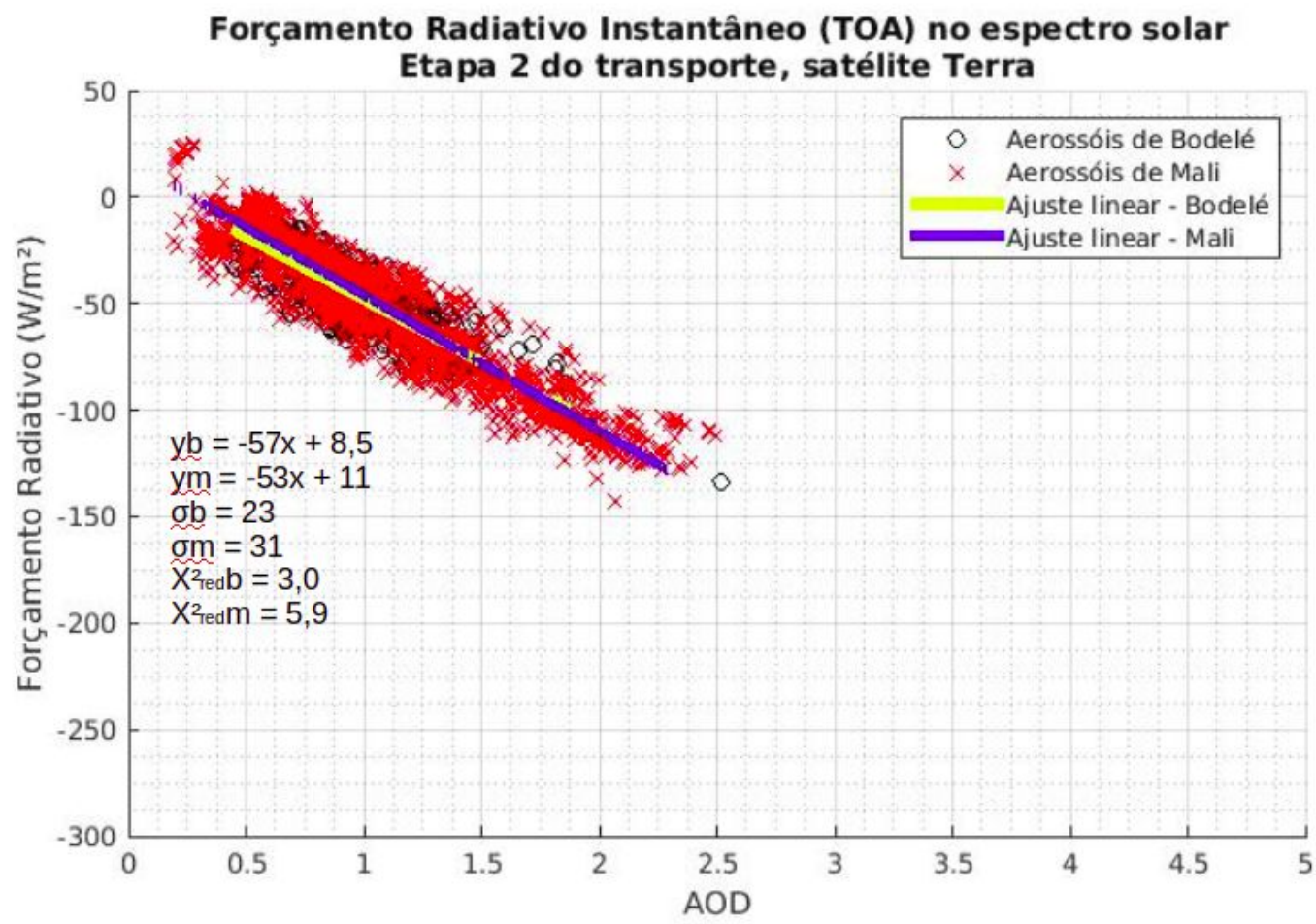

Figura 36 - Relação AOD (em $550 \mathrm{~nm}$ ) x FRA instantâneo no espectro solar no TOA na etapa 2, estimados pelo satélite Terra. Letra $\mathrm{b}$ ou $\mathrm{m}$ após parâmetros estatísticos indica Bodelé ou Mali. Incertezas (S) dos parâmetros a e $b$ da regressão linear: $S_{a b}=0,84 ; S_{b b}=0,78 ; S_{a m}=0,30 ; S_{b m}=0,31$.

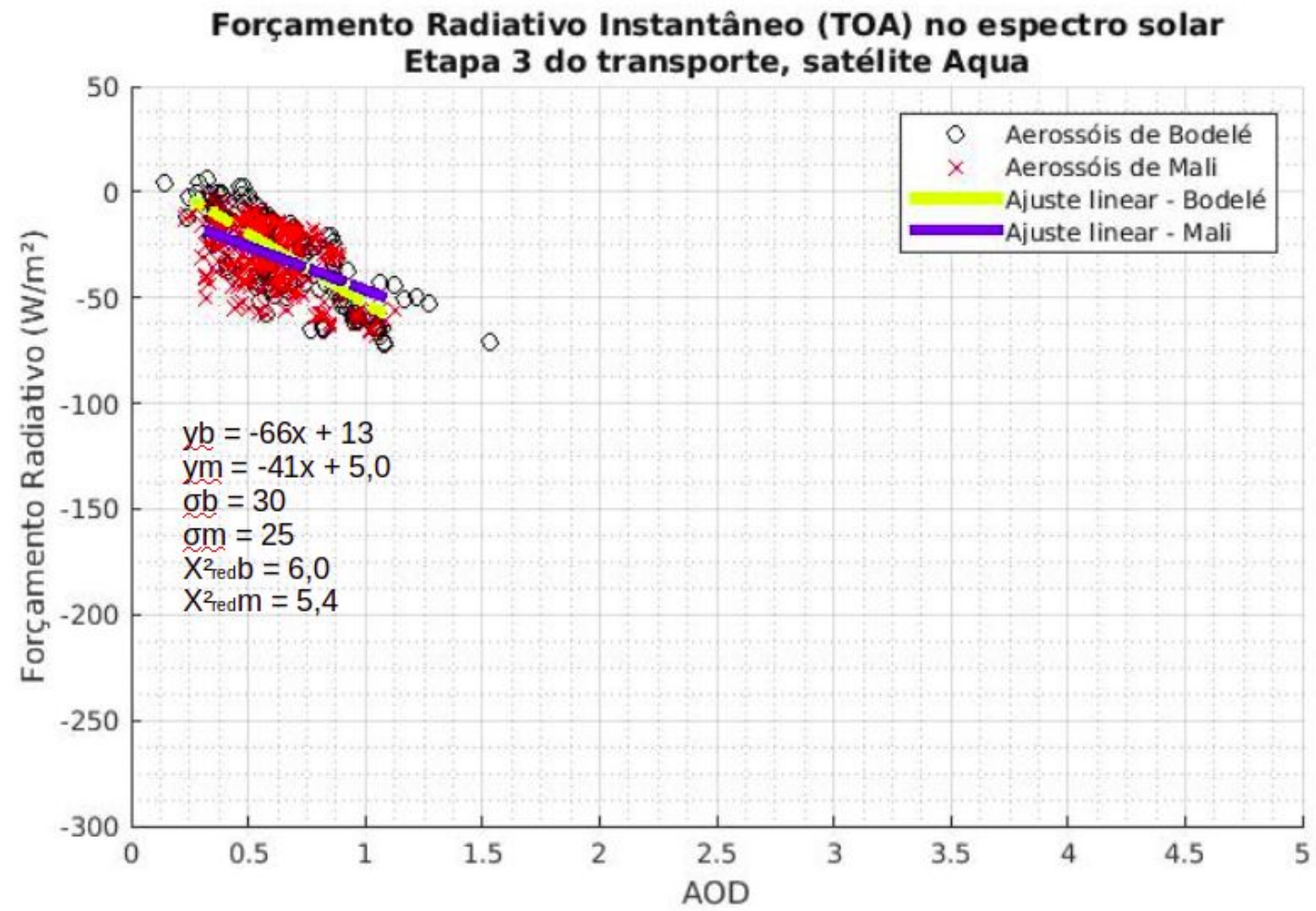

Figura 37 - Relação AOD (em 550 nm) x FRA instantâneo no espectro solar no TOA na etapa 3, estimados pelo satélite Aqua. Letra b ou $\mathrm{m}$ após parâmetros estatísticos indica Bodelé ou Mali. Incertezas (S) dos parâmetros a e $b$ da regressão linear: $S_{a b}=1,30 ; S_{b b}=0,83 ; S_{a m}=1,62 ; S_{b m}=0,99$. 


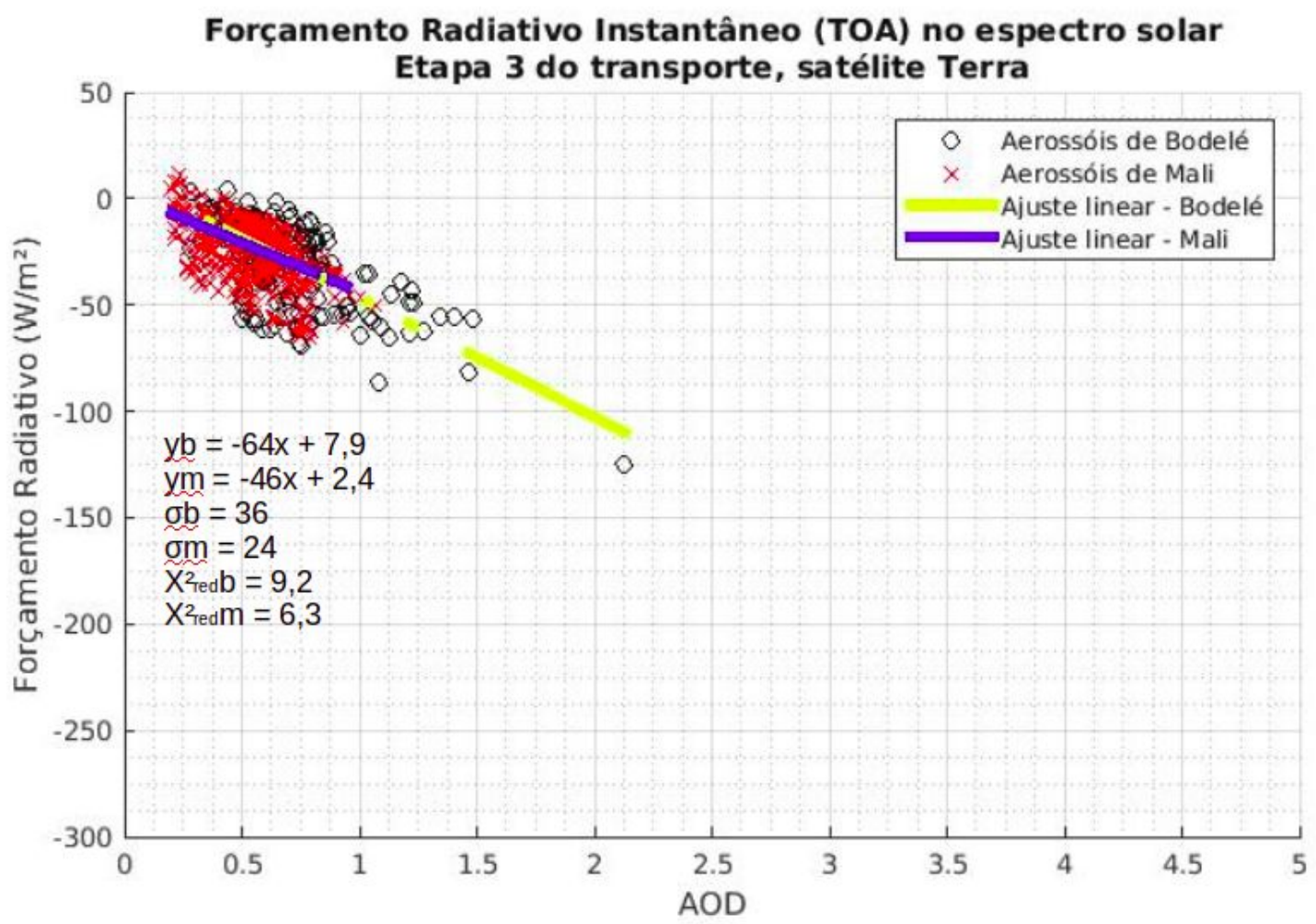

Figura 38 - Relação AOD (em 550 nm) x FRA instantâneo no espectro solar no TOA na etapa 3, estimados pelo satélite Terra. Letra $b$ ou $\mathrm{m}$ após parâmetros estatísticos indica Bodelé ou Mali. Incertezas (S) dos parâmetros a e $b$ da regressão linear: $S_{a b}=1,75 ; S_{b b}=1,23 ; S_{a m}=1,37 ; S_{b m}=0,78$.

$\mathrm{Na}$ evolução das plumas de aerossol, entre as etapas, a AOD diminui, devido a processos de deposição das partículas, e o FRA segue a redução, em valores absolutos. Juntamente a essa redução, houve uma diminuição no padrão de linearidade na relação entre o FRA instantâneo e a AOD, destacado pelo aumento do valor do chi-quadrado reduzido da etapa 1 até a etapa 3. Nos ajustes lineares dos dados da etapa 1, o valor do chi-quadrado reduzido esteve em torno de 2 , enquanto que na etapa 3 , o ajuste feito através do método dos mínimos quadrados teve o chi-quadrado reduzido em torno de 6 , chegando até 9,2 para o ajuste aos dados de aerossol originário de Bodelé estimado pelas observações do satélite Terra. A diminuição na qualidade do ajuste linear observada na etapa 3 , reflete nas estimativas de eficiência diária de forçamento radiativo para essa etapa, aspecto discutido na seção 4.4. Acredita-se que essa mudança do comportamento, inicialmente linear, da relação entre o FRA instantâneo no espectro solar no TOA e a AOD esteja relacionado a dois fatores. Um deles físico, que diz respeito aos 
processos de envelhecimento do aerossol e desestruturação das plumas, já mencionado neste estudo. O outro fator, estatístico, diz respeito à diminuição de pontos e concentração destes pontos em valores baixos de AOD, com alta variabilidade de FRA.

É de se destacar também o comportamento do FRA das duas origens. A origem do aerossol e o horário de passagem dos satélites não pareceram afetar significativamente o comportamento do forçamento radiativo, não mudando significativamente o resultado, apesar de, nas observações do satélite Aqua, o comportamento do FRA não ser idêntico para as duas origens de aerossol. Há de se observar que as medidas instantâneas aqui apresentadas concentram observações com maior ocorrência de ângulo zenital solar em torno de $30^{\circ}$, e que a passagem do satélite Aqua acontece no período da tarde (hora local) aproximadamente 3 horas depois da passagem do satélite Terra, que acontece no final da manhã (hora local). A variação do ângulo zenital solar é um fator importante para o impacto radiativo do aerossol no fluxo, e isso pode ser observado mesmo nos gráficos com valores instantâneos apresentados: apesar de apresentar linearidade na relação com a AOD, o FRA tem um desvio padrão elevado, se considerada a variabilidade dos valores em torno da reta de ajuste. As diferentes geometrias do sol nas observações são um fator importante para esse comportamento. Entretanto, a demonstração do efeito de diferentes ângulos zenitais solares nas observações requer mais informações do que abordado neste estudo, uma vez que a própria atmosfera no momento de cada observação é outro fator determinante à variação dos valores em torno da reta de ajuste.

Como já discutido, a eficiência de forçamento radiativo (ef) é o forçamento radiativo de aerossol por unidade de profundidade óptica. Devido à relação linear entre FRA e AOD, a ef pode ser calculada como simplesmente o coeficiente angular da reta de ajuste linear entre as variáveis. As figuras 39 e 40 mostram os valores médios de eficiência de forçamento radiativo instantâneo para os aerossóis de cada origem, considerando todos os valores de ângulo zenital solar. 
Eficiência instantânea de forçamento radiativo - Aerossóis de Bodelé

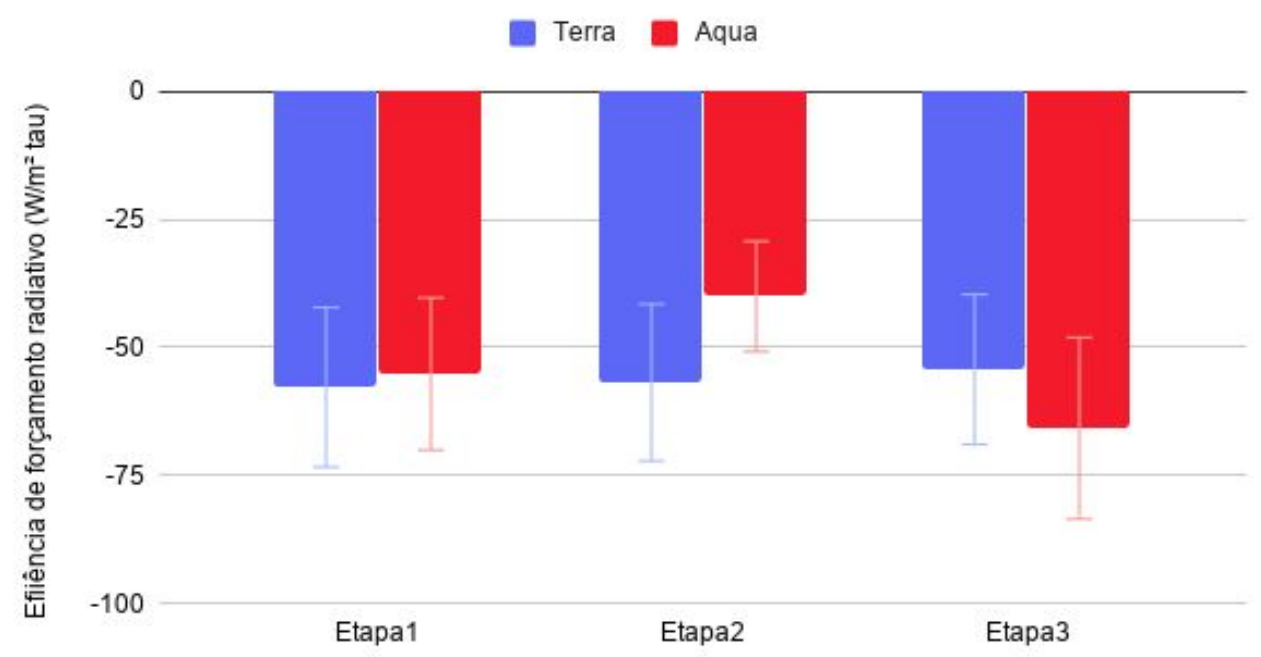

Figura 39 - Eficiência instantânea média de forçamento radiativo para aerossol originário de Bodelé, estimado a partir da passagem dos satélites Terra e Aqua.
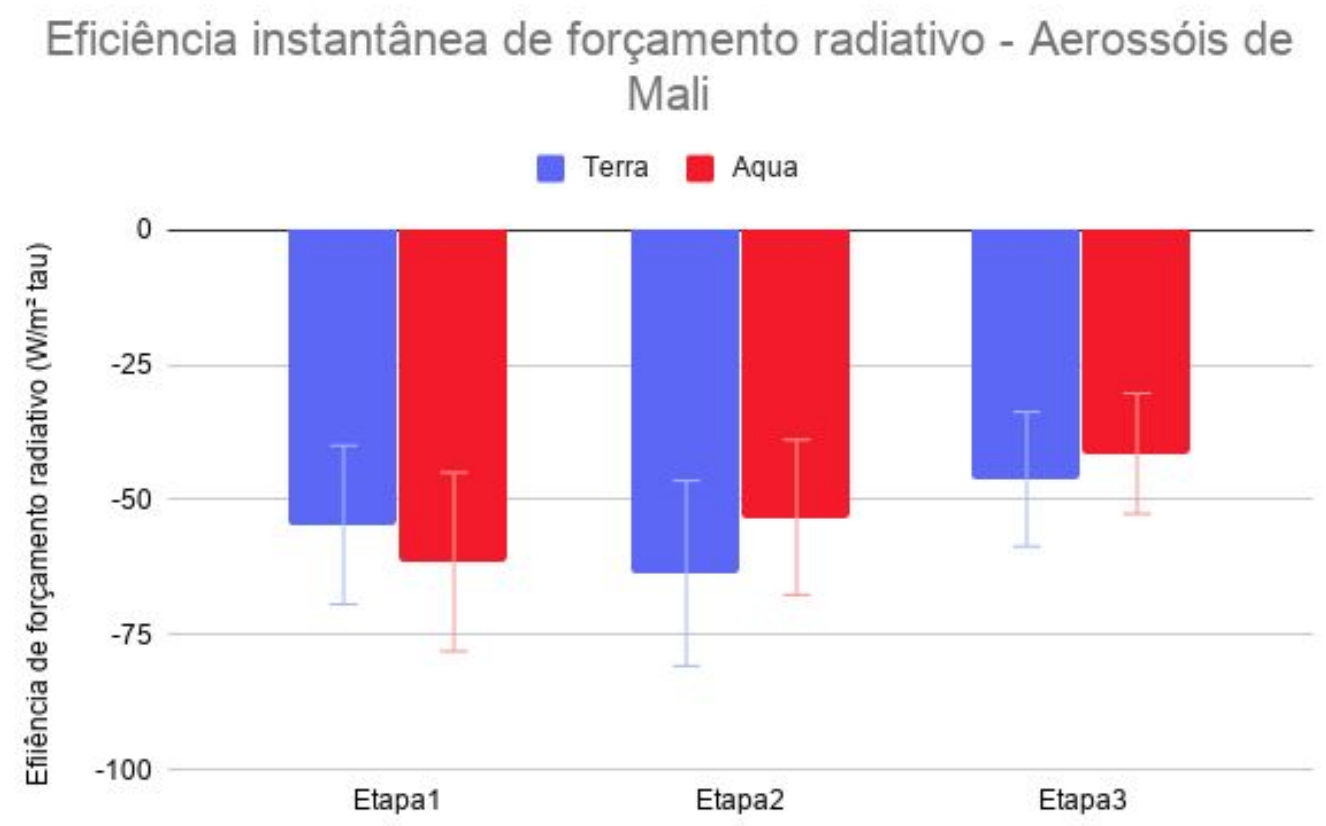

Figura 40 - Eficiência instantânea média de forçamento radiativo para aerossol originário do norte de Mali, estimado a partir da passagem dos satélites Terra e Aqua.

Os gráficos mostram alguma variação na eficiência instantânea entre os satélites e entre as etapas, entretanto, devido ao elevado desvio padrão, não é possível caracterizar essa variação como causada pela diferença entre a estrutura 
ou propriedades ópticas das plumas, uma vez que elas ocorrem dentro da incerteza associada à geometria do sol e à interação da radiação com a atmosfera. No que diz respeito à comparação entre as fontes, também não é possível fazer distinção estatisticamente significativa entre a eficiência instantânea dos aerossóis de Bodelé com os aerossóis de Mali.

A figura 41 mostra o ângulo zenital médio do sol para as observações de cada satélite em cada etapa do transporte, com o desvio padrão representado na barra de erros. Nas medidas de ambos os satélites para todas as etapas, o ângulo zenital médio do sol esteve entre aproximadamente 20 e 30 graus.
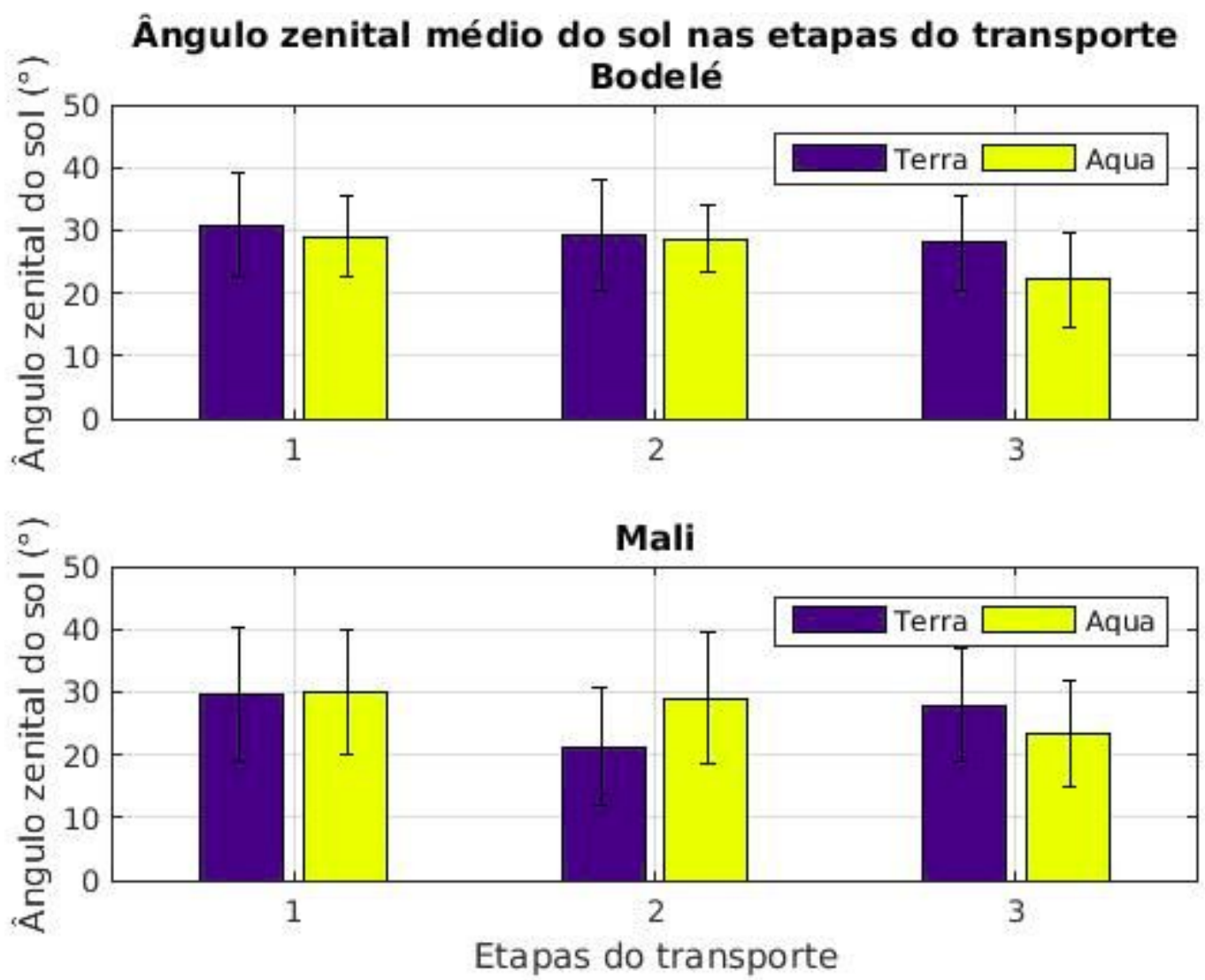

Figura 41 - Ângulo zenital médio do sol para as medições de cada satélite, em cada etapa, para cada origem dos aerossóis.

Não é possível traçar um padrão claro de similaridade entre o ângulo zenital médio e as eficiências instantâneas. Entretanto, um valor relativamente menor (em módulo) observado na segunda etapa do transporte, para os aerossóis de Bodelé (figura 39) nas medições do satélite Aqua, é de todos o que tem o menor desvio padrão, ou seja, menor variabilidade do ângulo zenital solar, com a média em $29,8^{\circ}$. 


\subsection{Areia do deserto do Saara na Amazônia}

Como já apresentado, 21 do total de 40 eventos de transporte chegaram à Amazônia, sendo 10 deles originários de Bodelé, outros 10 originários de Mali e 1 evento com origem indeterminada. Ainda sobre o oceano, na costa da América do Sul (a oeste de $40^{\circ} \mathrm{W}$ e ao sul de $6,5^{\circ} \mathrm{N}$ ), os eventos das duas origens tiveram AOD e FRA no espectro solar no TOA similares. A AOD média foi de 0,63 para os aerossóis do norte do Chade (desvio padrão = 0,31), e de 0,65 para os aerossóis do norte de Mali (desvio padrão $=0,19$ ). O FRA foi respectivamente $-33 \mathrm{~W} / \mathrm{m}^{2}$ (desvio padrão $=27 \mathrm{~W} / \mathrm{m}^{2}$ ) e $-36 \mathrm{~W} / \mathrm{m}^{2}$ (desvio padrão $\left.=36 \mathrm{~W} / \mathrm{m}^{2}\right)$, para ângulo zenital solar médio de $30^{\circ}$ e $24^{\circ}$.

Entretanto, sobre o continente um fator já conhecido dificultou as medidas: as nuvens. Segundo Reboita et al. (2010), os máximos pluviométricos no nordeste da região Amazônica, por onde as plumas de aerossol entram no continente, ocorrem no primeiro semestre. Os mesmos autores associaram tal comportamento à atuação da Zona de Convergência Intertropical, convecção local, e uma série de outros sistemas sinóticos e de mesoescala. Por esse motivo, as nuvens são um fator importante a ser considerado, mesmo diante da filtragem para nuvens já descrita, levando em conta a resolução do produto CERES utilizado (20 km x $20 \mathrm{~km}$ ) e a escala de 2 km em que se compreende convecção local (Orlanski, 1975), além da alta densidade de nuvens aumentar a possibilidade de nuvens próximas afetarem os fluxos medidos no TOA. Quanto às observações, não foi possível identificar os padrões já observados sobre o oceano de relação entre o FRA e a AOD. As figuras 42 e 43 mostram essa relação calculada para observações sobre o continente para eventos de transporte que chegaram à Amazônia oriundos das duas origens. 


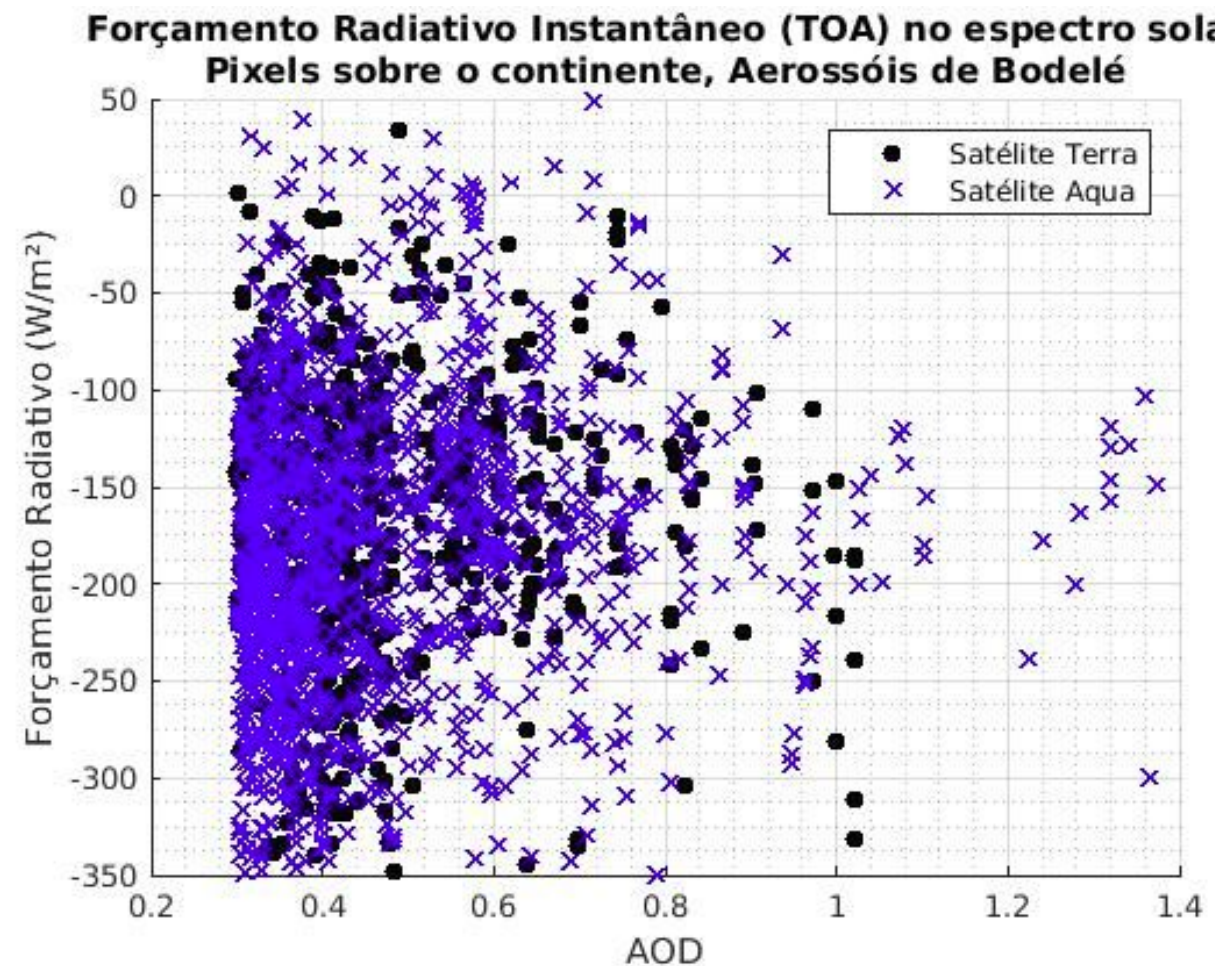

Figura 42 - Relação AOD x FRA instantâneo no espectro solar no TOA sobre o continente - Aerossóis de Bodelé

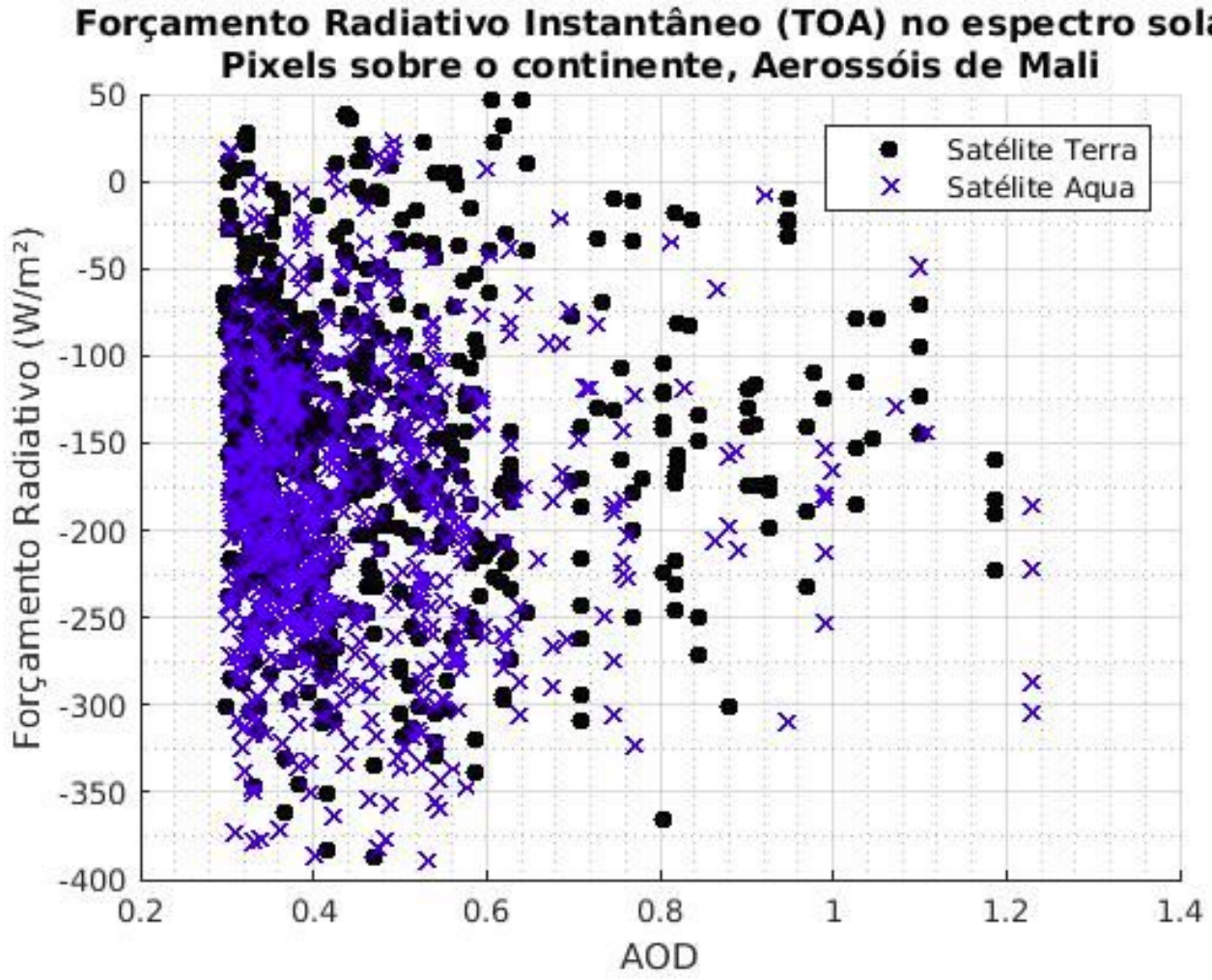

Figura 43 - Relação AOD x FRA instantâneo no espectro solar no TOA sobre o continente - Aerossóis de Mali. 
O efeito indireto dos aerossóis do deserto do Saara, já estudado por Sassen et al. (2003), também é um aspecto a ser considerado ao interpretar o que foi observado. A intensa convecção na região amazônica é capaz de dissipar a estrutura das plumas através dos processos de nucleação da nuvem tendo os aerossóis do deserto do Saara como núcleos de condensação, e como já foi discutido, a estrutura das plumas é um importante aspecto para o impacto radiativo do aerossol. Sem a estrutura vertical das plumas, o efeito direto dos aerossóis é minimizado, e então, apesar de não ter sido possível estimar o forçamento radiativo sobre o continente, é possível saber que ele não é igual ou maior do que o que foi observado antes da pluma chegar à Amazônia. Além das nuvens, os aerossóis da própria floresta se fazem presentes nesse contexto. Artaxo et al. (1988) mostraram que a floresta é uma importante fonte de aerossóis para a atmosfera. Assim, é esperado que as plumas de aerossol que chegam à Amazônia se misturem com os aerossóis originários da floresta, e conforme adentram o continente tenham, na média, a alteração das suas propriedades ópticas. Por esse motivo, é possível que muitos dos pontos observados representem maior quantidade de outros tipos de aerossol do que de areia do deserto.

A comparação da distribuição de tamanho entre a fase inicial do transporte e a chegada à Amazônia dá uma noção do quão diferente é a pluma entre uma etapa e outra. O evento de 13 de fevereiro de 2001 é o único dentre os 40 inclusos neste estudo em que há dados do AERONET disponíveis numa estação no início do transporte, em Cabo Verde (16,7 $7^{\circ} \mathrm{N} 22,9^{\circ} \mathrm{W}$ ), e numa estação já na Amazônia, no

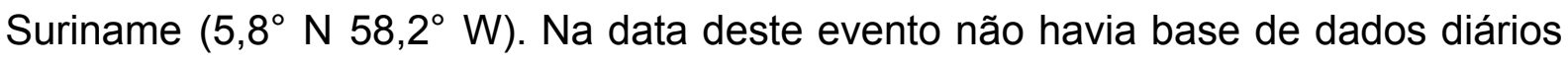
disponíveis na plataforma do Hysplit para verificar a trajetória com este modelo. Porém, foi possível identificar a pluma de aerossóis nos primeiros dias do evento em torno do arquipélago de Cabo Verde, e posteriormente a pluma foi identificada até o dia 21 de fevereiro sobre o oceano na costa da América do Sul. A figura 44 mostra a localização de todos os pixels observados neste evento, destacando a localização das duas estações AERONET, e a figura 45 mostra a AOD em cada um dos pixels. 


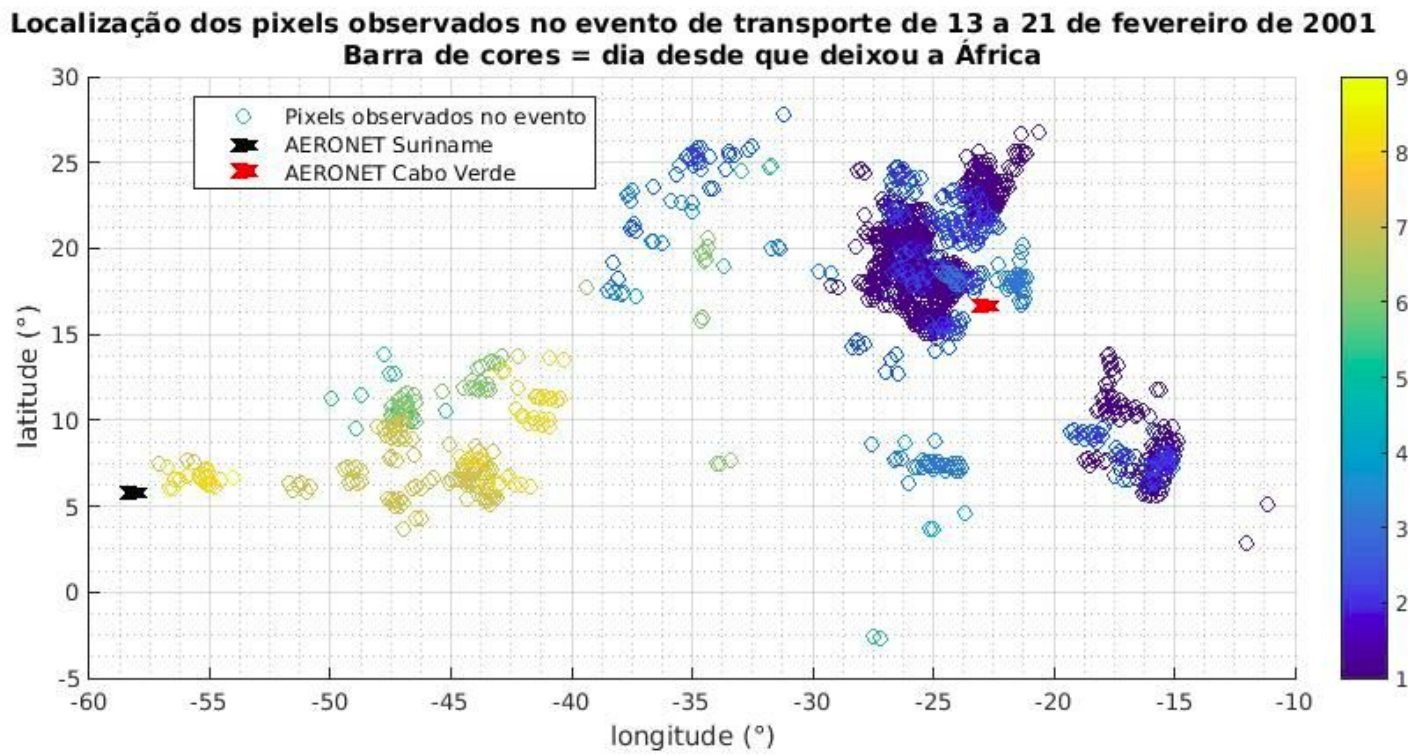

Figura 44 - Deslocamento dos aerossóis em evento de transporte de 13 a 21 de fevereiro de 2001. Sítio AERONET do Suriname e de Cabo Verde destacados em preto e vermelho, respectivamente.

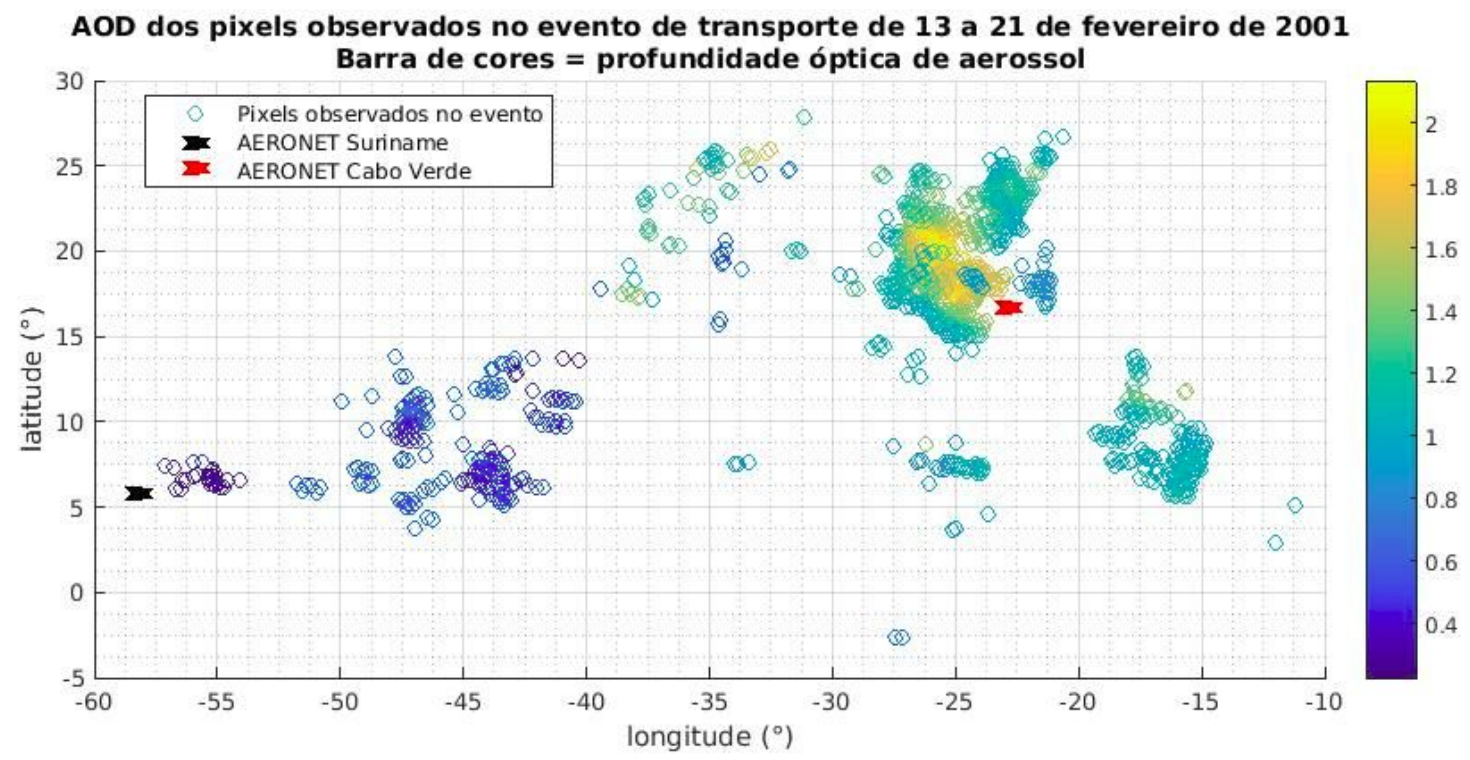

Figura 45 - Profundidade óptica de aerossol em evento de transporte de 13 a 21 de fevereiro de 2001. Sítio AERONET do Suriname e de Cabo Verde destacados em preto e vermelho, respectivamente.

As informações apresentadas são da distribuição de tamanho e do albedo simples nas duas estações. Contudo, não há dados de nível 2.0 de processamento para o albedo simples no Suriname no dia 13 de fevereiro de 2001, então o dado apresentado se refere ao nível 1.5 de processamento, que passa por filtragem de nuvens e controle de qualidade, mas pode não ter a aplicação de calibração final. A distribuição de tamanho já mostra grande diferença entre as duas observações. No 
dia 13 de fevereiro, sobre Cabo Verde, a maior concentração volumétrica é de partículas com raio acima de $2 \mu \mathrm{m}$ (figura 46). No dia 22 de fevereiro, sobre o Suriname, além do volume de partículas ser uma ordem de grandeza menor que em Cabo Verde (figura 47), o tamanho das partículas está mais distribuído, com grande presença de aerossóis da moda fina em relação ao total.

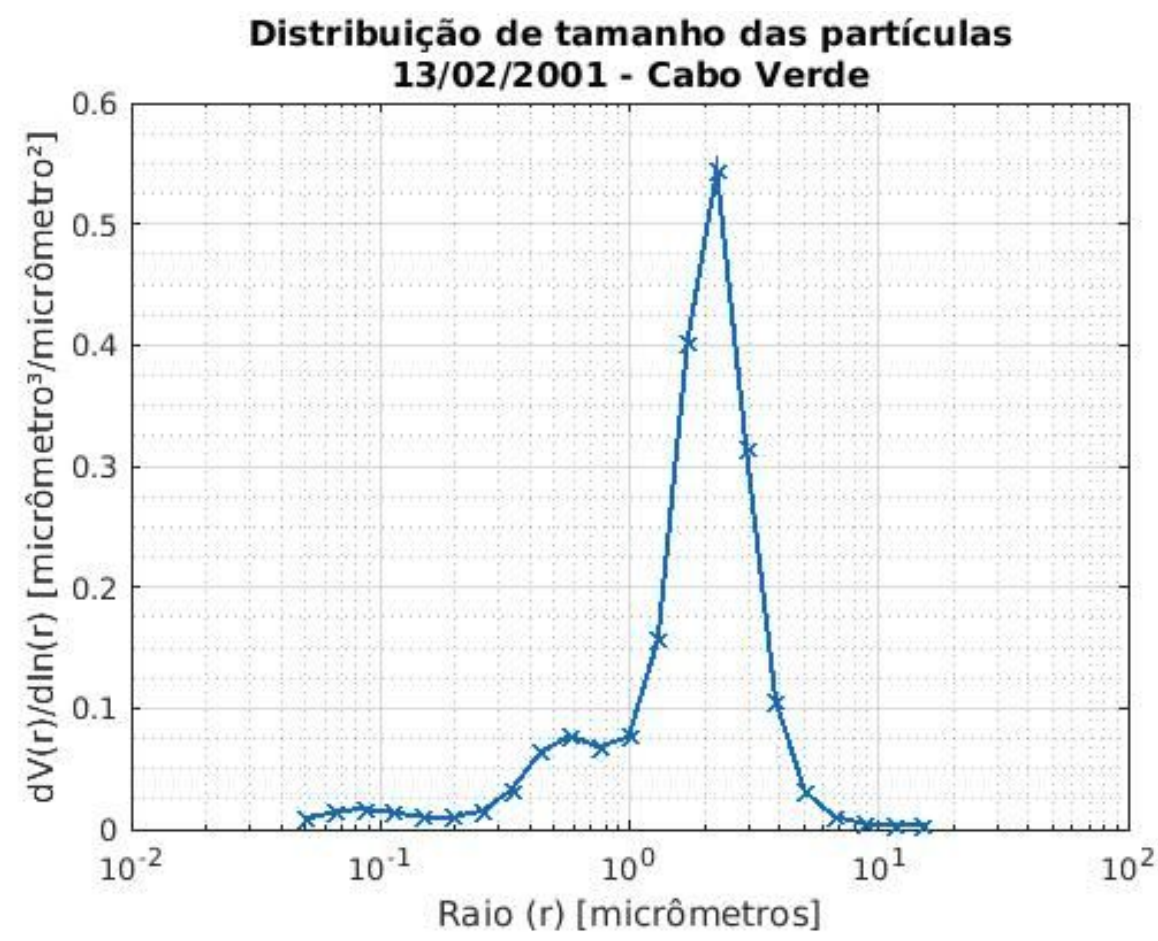

Figura 46 - Distribuição de tamanho das partículas em 13 de fevereiro de 2001, no sítio AERONET de Cabo Verde. 


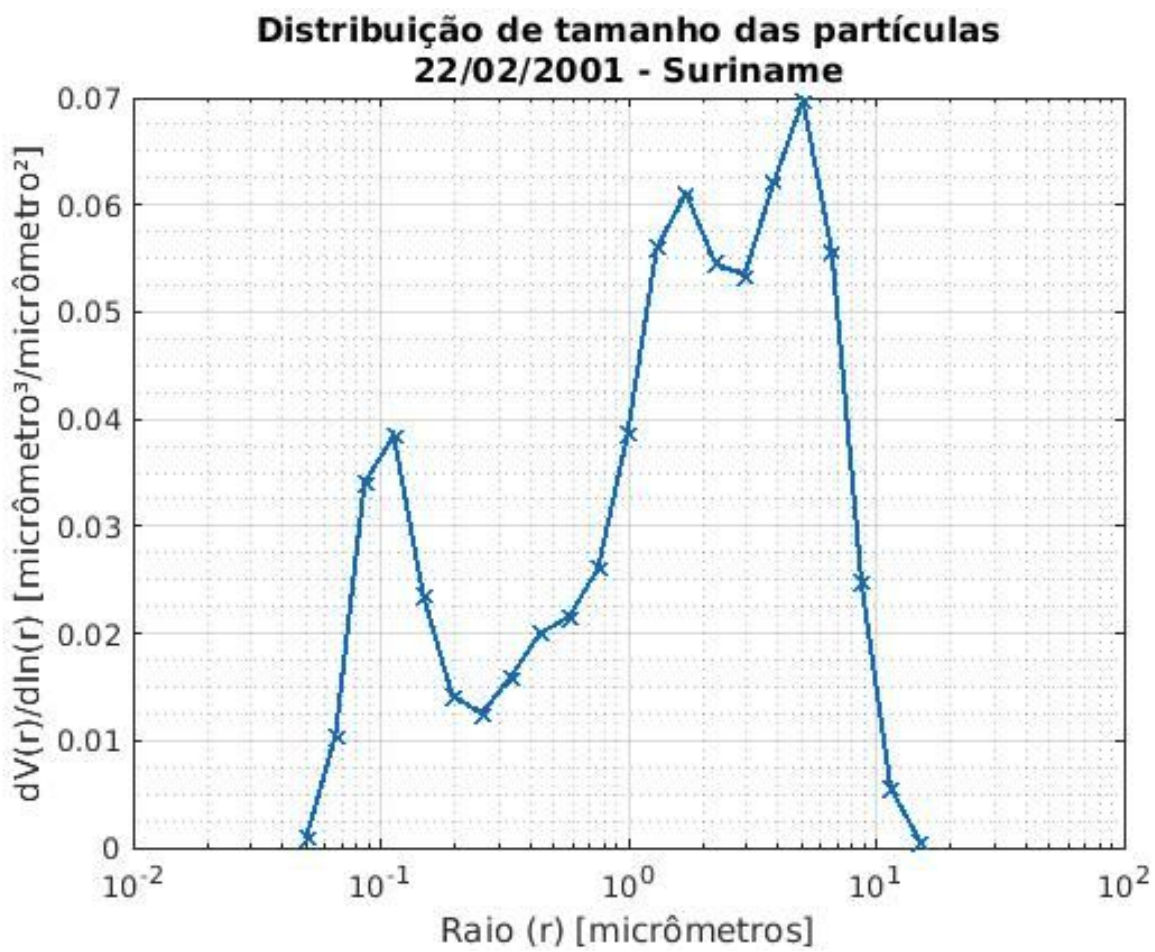

Figura 47 - Distribuição de tamanho das partículas em 22 de fevereiro de 2001, no sítio AERONET do Suriname. Neste dia foi observada a chegada de pluma de aerossóis originária do deserto do Saara.

A comparação entre o albedo simples em Cabo Verde e no Suriname mostra uma diferença significativa nessa variável nas duas localidades. $\mathrm{O}$ albedo simples estimado em Cabo Verde mostra um comportamento esperado do albedo simples para aerossóis do deserto do Saara, como já mostrado por Dubovik et al. (2002), com uma variação de 0,90 a aproximadamente 0,99 no espectro visível, e estabilizando o valor aproximado de 0,99 no infravermelho próximo. No sítio AERONET no Suriname, o albedo simples varia entre 0,89 e 0,91 no espectro visível, com uma uma tendência de aumento no infravermelho próximo. 


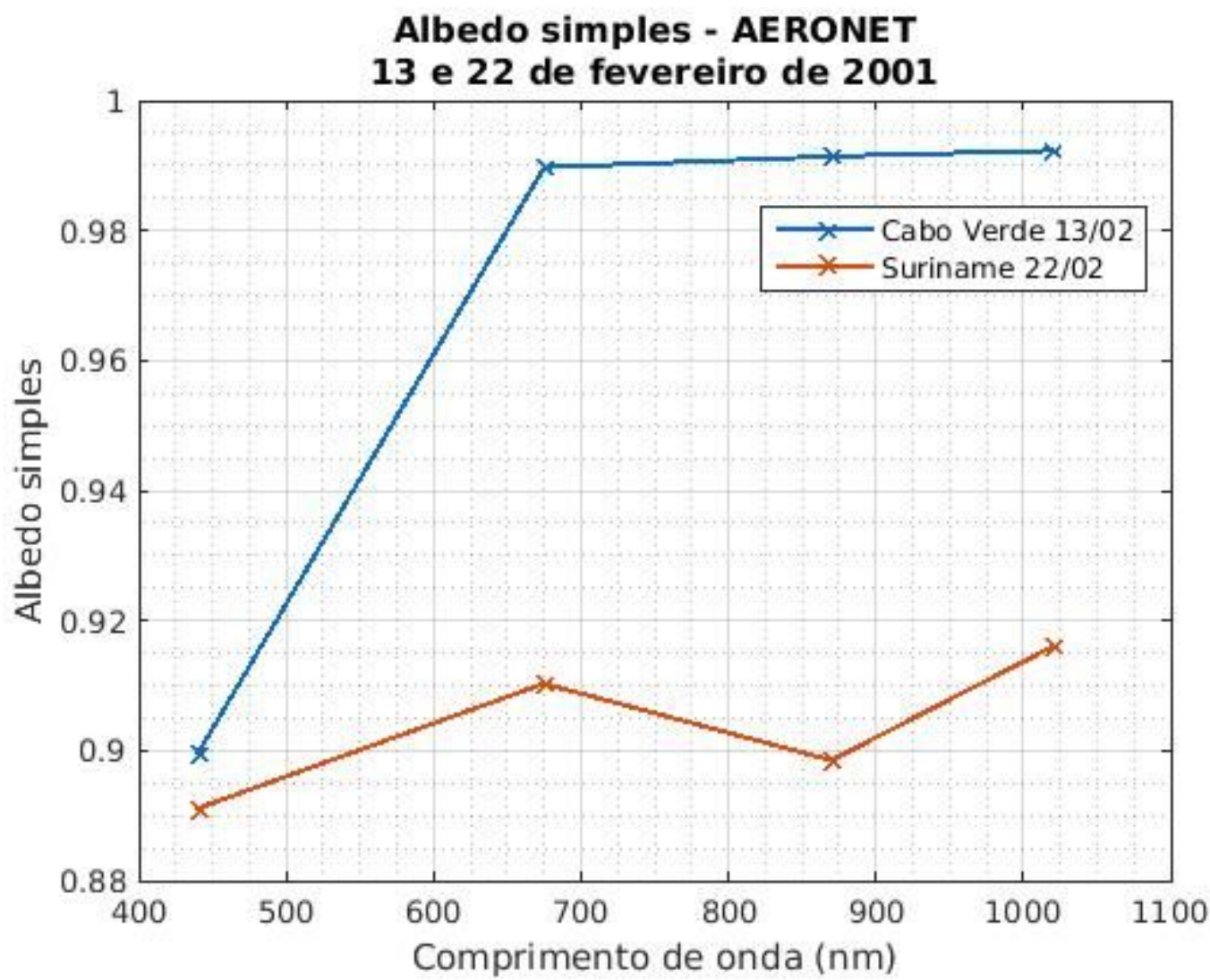

Figura 48 - Albedo simples das partículas em 13 de fevereiro de 2001 no sítio AERONET de Cabo Verde e em 22 de fevereiro de 2001 no sítio AERONET do Suriname.

Deve-se considerar a possibilidade de uma presença significativa de aerossóis de outras origens no que foi observado no Suriname. Num estudo que utiliza uma sítio de medição na cidade de Serra do Navio, no estado do Amapá (aproximadamente $550 \mathrm{~km}$ distante da estação AERONET do Suriname), Artaxo et al. (1993) destacaram a presença de aerossóis de origem marinha e de origem de emissões da própria floresta na região norte da bacia Amazônica, onde a queima de biomassa, principalmente no período chuvoso, não é uma fonte importante de aerossóis. Este é mais um indicativo de que, o que se vê na distribuição de tamanho no Suriname, na realidade representa a mistura de aerossóis de diferentes fontes, o que certamente afeta também o albedo simples estimado. Contudo, os dados de albedo simples do AERONET são um forte indicativo da diminuição do albedo simples das plumas de aerossol do deserto do Saara com o seu distanciamento do continente africano, hipótese reforçada com a discussão sobre a eficiência diária de forçamento radiativo. 
Devido ao que mostraram os gráficos, ao que se observou na evolução do FRA e da AOD com o deslocamento das plumas, e ao que foi comentado da literatura, acredita-se que na região amazônica, os efeitos diretos dos aerossóis do deserto do Saara na escala regional a global sejam pequenos (em relação aos efeitos da própria pluma nas etapas anteriores). Não foi possível avaliar a diferença do FRA ou do ef entre os aerossóis de cada origem e nem calcular valores sobre o continente. Mas baseado nas plumas ainda sobre o oceano, sabe-se que a AOD associada somente aos aerossóis do deserto do Saara chegam à Amazônia com valores em torno de 0,6 com FRA instantâneo -30 W/m², com ângulo zenital solar em torno de $30^{\circ}$. Os resultados e discussão da eficiência diária de forçamento radiativo, apresentados na próxima seção, mostram que, na escala diária, esse efeito direto dos aerossóis do deserto do Saara na Amazônia tende a ser ainda menor e que o contraste entre o impacto radiativo da areia quando deixa o deserto e quando chega à Amazônia é grande.

\subsection{Eficiência diária de forçamento radiativo}

Como já apresentado na metodologia, devido à não disponibilidade de observações cobrindo todos os valores de ângulo zenital solar, e sendo a eficiência diária calculada através de uma integração que envolve a variação de ângulo zenital solar, se faz necessária a utilização de ferramentas de simulação para extrapolar os valores de irradiância ascendente no TOA, e posteriormente albedo, para todos os valores de $\theta$, ajustando as simulações aos dados observacionais disponíveis. Neste estudo são utilizadas simulações do solver DISORT no código de transferência radiativa LibRadtran.

O albedo simples em $550 \mathrm{~nm}$ é a variável independente que é alterada no input do modelo a fim de achar o melhor ajuste aos pontos observados. E os valores de albedo simples com os quais foram encontradas as melhores curvas de $\frac{d(\text { albedo })}{d(A O D)}$ em função do cosseno do ângulo zenital do sol já evidenciam uma diferença nas propriedades ópticas dos aerossóis das duas origens. Para os aerossóis originários de Bodelé na primeira etapa do transporte, o valor de albedo simples que resultou num melhor ajuste dos valores simulados aos observados foi de 0,935; na segunda etapa do transporte esse valor diminuiu para 0,915 . A raiz do erro médio quadrático 
para o ajuste de cada uma das etapas foi de 0,0048 e 0,0058 respectivamente. 0 chi-quadrado reduzido para a curva de ajuste foi de 1,7 para a primeira etapa e de 1,9 para a segunda etapa, não havendo desacordo significativo entre a curva simulada e os pontos observados a um nível de confiança de $5 \%$. Para os aerossóis originários de Mali, os melhores ajustes foram encontrados com albedo simples de 0,89 para a primeira etapa do transporte e de 0,88 para a segunda etapa. A raiz do erro médio quadrático nesses casos foi 0,0028 para a etapa 1 e de 0,0025 para a etapa 2. O chi-quadrado reduzido da curva de ajuste para a etapa 1 foi 0,83 e para a etapa 2 foi 0,58 , também não havendo desacordo significativo entre os pontos observados e a curva de ajuste a um nível de confiança de $5 \%$. As figuras 49 e 50 mostram os melhores ajustes encontrados no modelo.
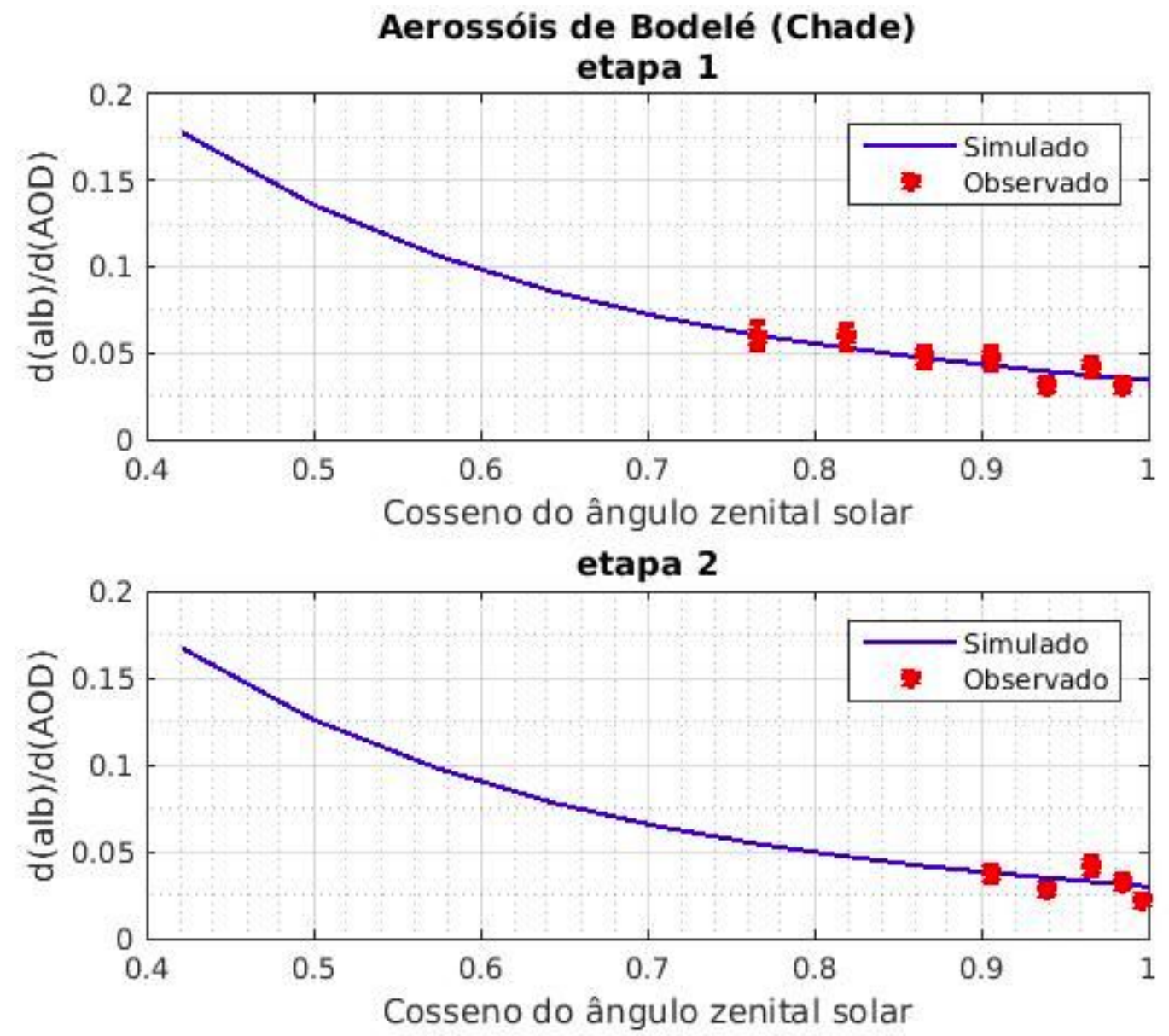

Figura 49 - Melhor ajuste de curva simulada de $\frac{d(a l b e d o)}{d(A O D)}$ em função do cosseno do ângulo zenital solar para a) a etapa 1 do transporte e b) a etapa 2 do transporte de aerossóis originários de Bodelé. 

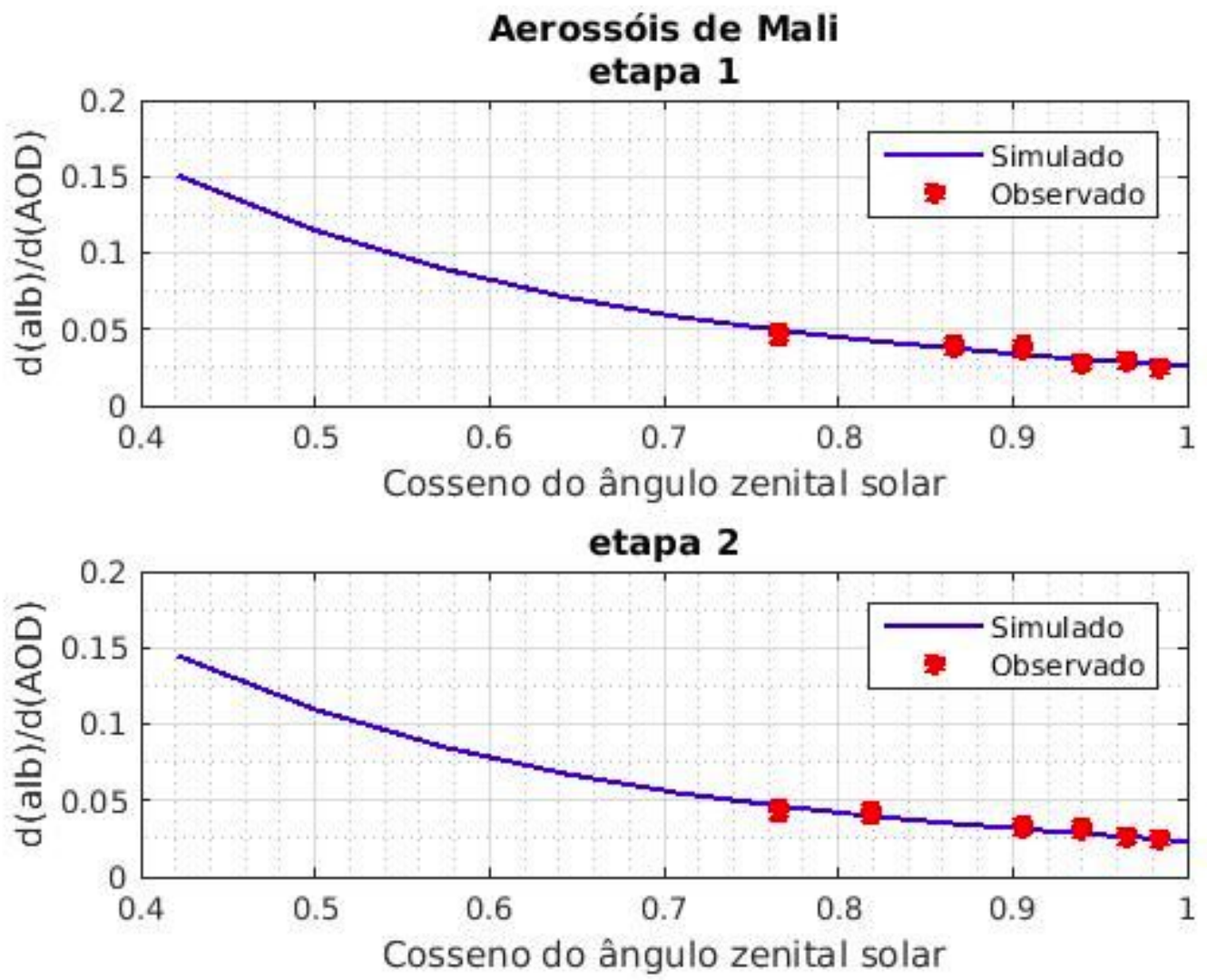

Figura 50 - Melhor ajuste de curva simulada de $\frac{d(\text { albedo) }}{d(A O D)}$ em função do cosseno do ângulo zenital solar para a) a etapa 1 do transporte e b) a etapa 2 do transporte de aerossóis originários do norte de Mali.

O teste do chi-quadrado reduzido também foi usado para testar a variabilidade das curvas de cada origem entre as etapas do transporte. A curva de albedo utilizada como melhor ajuste para a etapa 1 foi testada junto aos pontos observacionais na etapa 2. Este teste para os aerossóis de Bodelé resultou num chi-quadrado reduzido de 4,2, o que mostra discordância significativa a um nível de confiança de $5 \%$. Já para os aerossóis de Mali, o resultado foi 0,38 , indicando concordância significativa entre eles ao nível de confiança de $5 \%$. Ou seja, neste caso a curva de ajuste da etapa 1 poderia ser usada para a simulação da etapa 2 sem comprometimento da significância estatística.

Para a etapa 3, mesmo com a utilização de menos pontos para a regressão linear, como já descrito na metodologia, foi possível a estimativa de $\frac{d(\text { albedo })}{d(A O D)}$ observado para para apenas um intervalo de ângulo zenital solar para os aerossóis de Bodelé, e para três intervalos de ângulo zenital solar para os aerossóis de Mali. 
As figuras 51 e 52 mostram estes pontos juntamente com as simulações para a etapa 2.

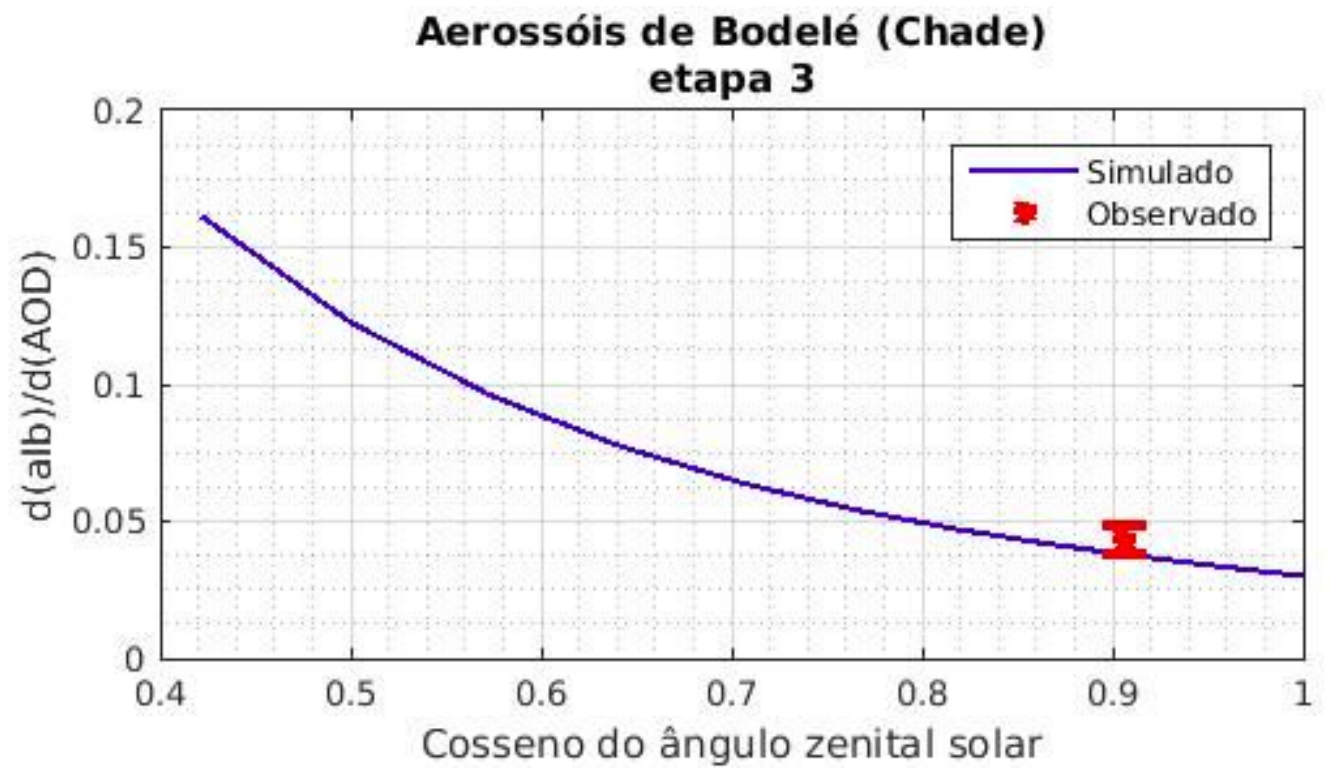

Figura 51 - Melhor ajuste de curva simulada de $\frac{d(\text { albedo) }}{d(A O D)}$ em função do cosseno do ângulo zenital solar para a etapa 2 do transporte de aerossóis originários da depressão de Bodelé comparado com observado na etapa 3.

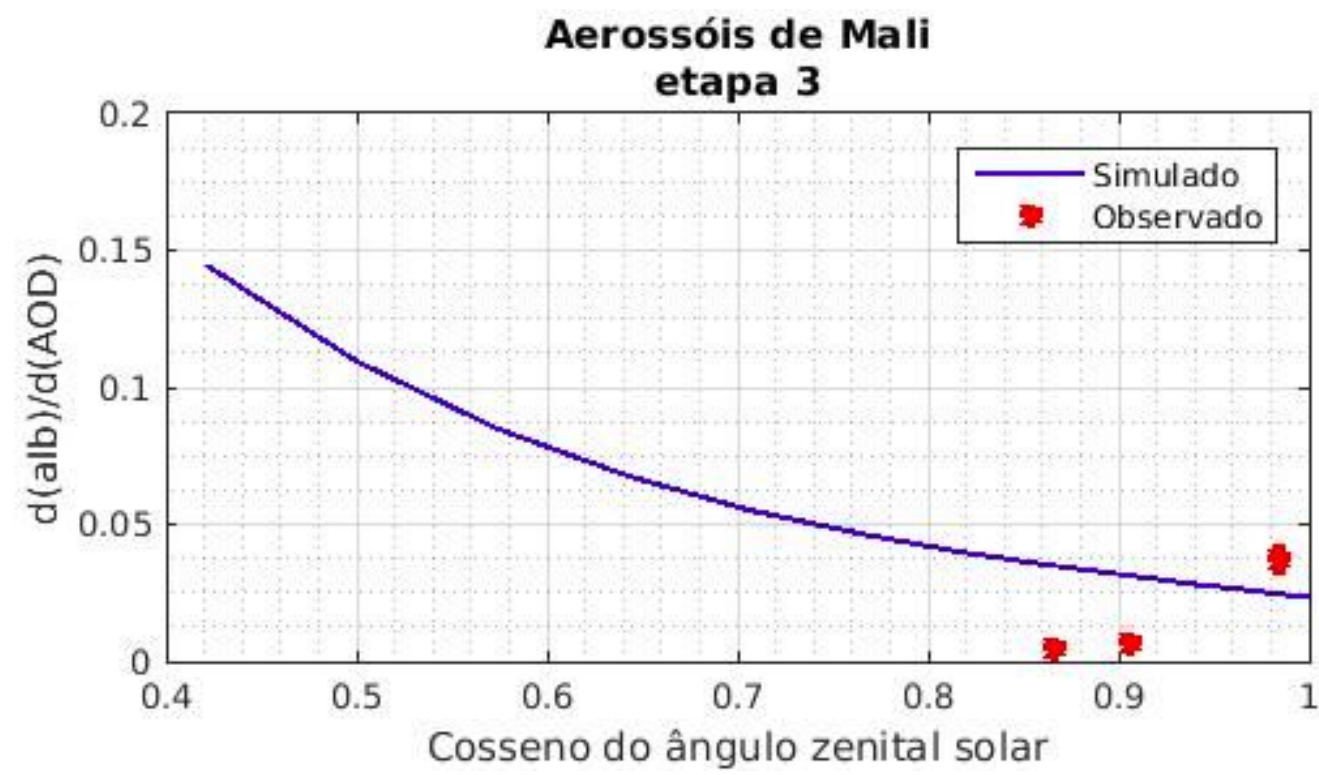

Figura 52 - Melhor ajuste de curva simulada de $\frac{d(\text { albedo) }}{d(A O D)}$ em função do cosseno do ângulo zenital solar para a etapa 2 do transporte de aerossóis originários do norte de Mali comparado com observado na etapa 3. 
À primeira vista fica clara a não qualidade do ajuste, e, no caso de Mali, a discrepância entre os pontos observados. A resposta para esse comportamento pode estar nas relações entre FRA instantâneo e AOD apresentadas na seção 4.2. O chi-quadrado reduzido para os ajustes lineares da etapa 3 são os mais elevados dentre as três etapas do transporte, mostrando uma perda de qualidade no ajuste linear à dispersão dos dados. Essa diminuição de resposta linear do FRA instantâneo em relação à AOD compromete a estimativa do $\frac{d(a l b e d o)}{d(A O D)}$ nessa etapa.

As incertezas do cálculo do $\frac{d(\text { albedo })}{d(A O D)}$ observado refletem nas estimativas da eficiência diária. Nesta etapa, então, elas são calculadas e posteriormente consideradas nas estimativas. Elas se devem a dois fatores principais: $\mathrm{O}$ primeiro deles é a incerteza dos instrumentos. Os fluxos radiativos apresentam uma incerteza de $2,2 \%$, enquanto que a $A O D$ tem uma incerteza de $0,03+5 \%$ sobre o oceano. Estes valores são utilizados no método de propagação de incertezas, para estimar a incerteza instrumental nos pontos observados nos gráficos. A incerteza calculada através deste método ficou entre $8 \%$ e 10\% dependendo do intervalo de ângulo zenital do sol. A segunda fonte de incerteza é a dispersão dos valores de albedo em função de AOD em torno da reta de regressão; o coeficiente angular desta reta representa o valor de $\frac{d(a l b e d o)}{d(A O D)}$ naquele intervalo de ângulo zenital. É o mesmo fenômeno observado na relação entre FRA instantâneo e AOD (como mostrado nas figuras 33 a 38), e apesar de utilizados intervalos de $5^{\circ}$ de ângulo zenital, ainda há uma certa dispersão em torno da reta de regressão. A incerteza associada a este fator foi calculada através do desvio padrão da média e também verificada com o método de propagação de incertezas, e os valores encontrados estiveram em torno de $1 \%$. A incerteza total então gira em torno de $9 \%$ a $11 \%$, e nos valores absolutos será arredondada sempre para o número inteiro seguinte.

O albedo simples do melhor ajuste aos aerossóis de cada origem já aponta uma diferença importante entre eles: uma maior capacidade de absorção de radiação solar pelos aerossóis vindos do norte de Mali. Outro fator de destaque é a diminuição do albedo simples com o deslocamento das plumas para oeste, evidenciado pela diminuição do albedo simples na segunda etapa, e já mostrado com os dados do AERONET mostrados na seção 4.3. Isso pode estar associado a 
dois processos principais. O primeiro é a deposição dos aerossóis maiores pela ação da gravidade ou mesmo por fatores meteorológicos, o que muda as propriedades ópticas médias da pluma. O segundo é o processo de envelhecimento dos aerossóis, que altera as propriedades das partículas individualmente. Os dois processos mencionados já apontam isso, mas é importante explicitar que as plumas de aerossóis são heterogêneas e não conservativas, tendo sua estrutura e propriedades constantemente alteradas por fatores externos durante o seu deslocamento.

Para cada etapa do transporte, a eficiência diária de forçamento radiativo foi calculada para todos os meses de janeiro a julho, tendo como base a geometria do dia 15 de cada mês e a latitude e longitude média dos pixels de cada etapa de transporte. Para a etapa 1 a latitude média era de $15^{\circ} \mathrm{N}$ e a longitude de $19^{\circ} \mathrm{W}$, e para a etapa 2 a latitude média era de $13^{\circ} \mathrm{N}$ e a longitude de $30^{\circ} \mathrm{W}$. Os resultados das eficiências para cada origem são apresentados nas figuras 53 e 54.

\section{Eficiência diária de forçamento radiativo (Aerossóis de Bodelé)}

etapa $1 \square$ etapa 2

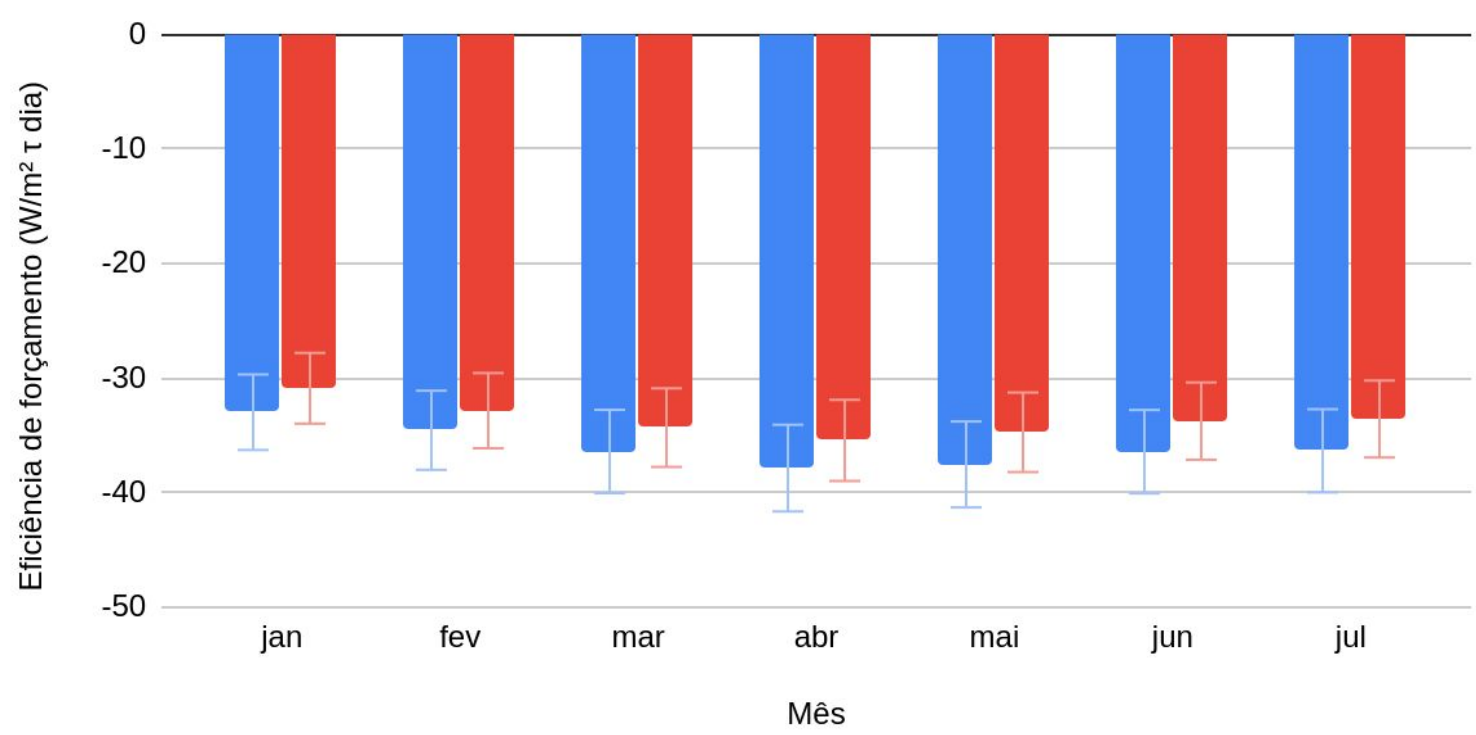

Figura 53 - Eficiência diária de forçamento radiativo de janeiro a julho, para os aerossóis de Bodelé, nas duas etapas do transporte. 


\section{Eficiência diária de forçamento radiativo (Aerossóis de Mali)}

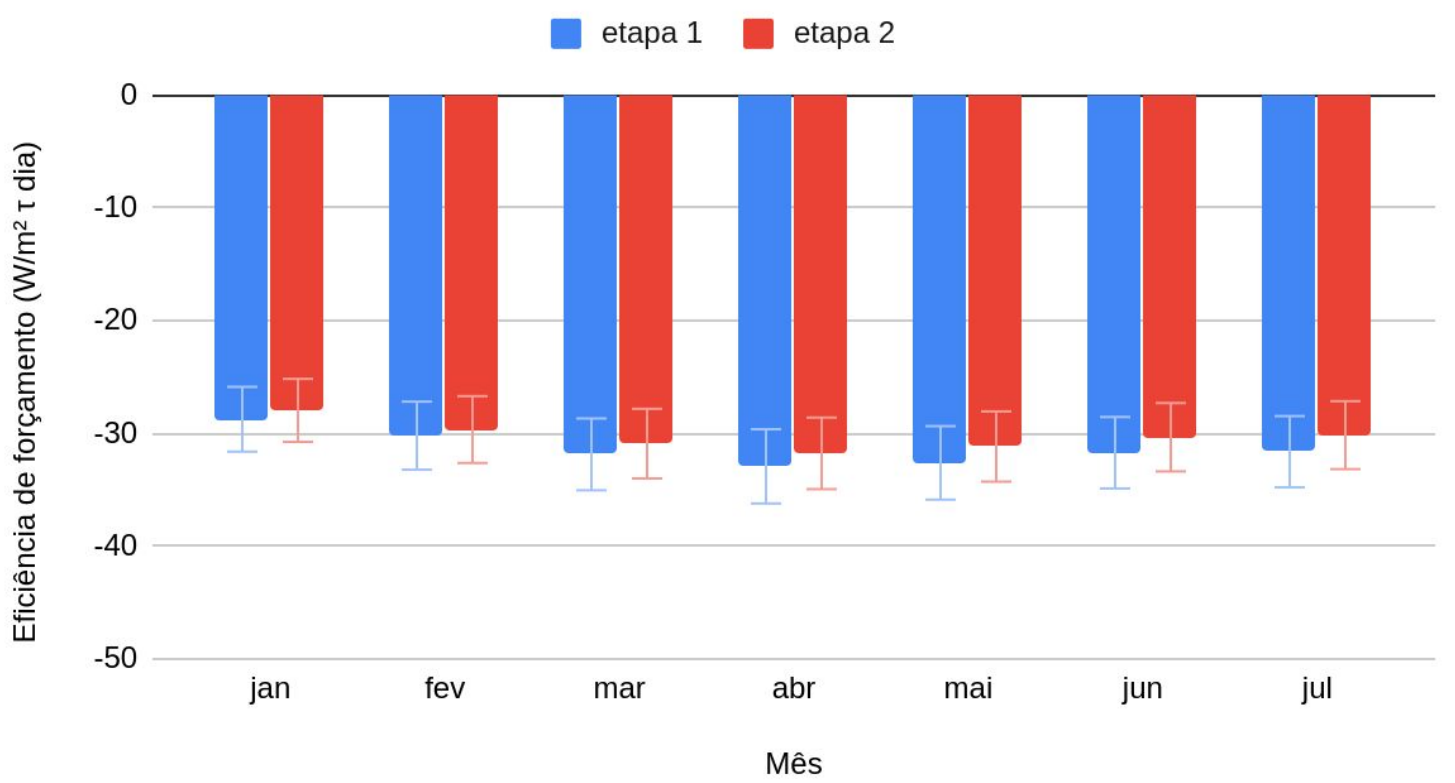

Figura 54 - Eficiência diária de forçamento radiativo de janeiro a julho, para os aerossóis de Mali, nas duas etapas do transporte.

A eficiência diária de forçamento radiativo dos aerossóis originários de Bodelé na etapa 1 foi de $-33 \pm 3 \mathrm{~W} /\left(\mathrm{m}^{2}\right.$ T dia) em janeiro, tendo seu máximo em abril, quando foi de $-38 \pm 4 \mathrm{~W} /\left(\mathrm{m}^{2} \mathrm{~T}\right.$ dia $)$, depois voltando a diminuir e sendo de $-36 \pm 4$ $\mathrm{W} /\left(\mathrm{m}^{2} \mathrm{~T}\right.$ dia) em julho. Na etapa 2 estes valores diminuem para $-31 \pm 4 \mathrm{~W} /\left(\mathrm{m}^{2} \mathrm{~T} d \mathrm{dia}\right)$, $-35 \pm 4 \mathrm{~W} /\left(\mathrm{m}^{2} \mathrm{~T}\right.$ dia $)$ e $-34 \pm 4 \mathrm{~W} /\left(\mathrm{m}^{2} \mathrm{~T}\right.$ dia $)$, respectivamente. A variação da eficiência de uma etapa para a outra foi testada com o método $t$ student ao nível de significância de 0,05 , e foi atestada a significância estatística. Aqui destaca-se o resultado para o mês de julho na etapa 1 , que pode ser diretamente comparado com o resultado da eficiência diária de forçamento radiativo estimada por Li et al. (2004). Naquele estudo os autores estimaram a eficiência diária do forçamento pelos aerossóis do deserto do Saara em $35 \pm 3 \mathrm{~W} /\left(\mathrm{m}^{2} \mathrm{~T}\right.$ dia) para o mês de julho, que é um dos meses com maior emissão de areia na depressão de Bodelé, como mostraram Liu et al. (2012). Isso mostra que o resultado encontrado neste estudo concorda com o resultado do estudo de 2004 , se considerarmos as incertezas.

Para os aerossóis originários do norte de Mali, a eficiência diária na etapa 1 foi de $-29 \pm 3 \mathrm{~W} /\left(\mathrm{m}^{2} \mathrm{~T}\right.$ dia) em janeiro, $-33 \pm 4 \mathrm{~W} /\left(\mathrm{m}^{2} \mathrm{~T}\right.$ dia $)$ em abril e de $32 \pm 4$ 
$\mathrm{W} /\left(\mathrm{m}^{2} \mathrm{~T}\right.$ dia $)$ em julho. Na etapa 2 os valores diminuem para $-28 \pm 3 \mathrm{~W} /\left(\mathrm{m}^{2} \mathrm{~T}\right.$ dia $),-32$ $\pm 4 \mathrm{~W} /\left(\mathrm{m}^{2} \mathrm{~T}\right.$ dia $)$ e $-30 \pm 3 \mathrm{~W} /\left(\mathrm{m}^{2} \mathrm{~T}\right.$ dia $)$. A diferença entre as estimativas para os aerossóis de Mali e para os aerossóis de Bodelé também foi testada com o método $t$ student ao nível de significância de 0,05 e foi atestada a significância estatística. A diferença entre o albedo simples utilizado nas simulações para o melhor ajuste às observações reflete numa diferença de até $5 \mathrm{~W} /\left(\mathrm{m}^{2} \mathrm{~T}\right.$ dia $)$ na eficiência diária de forçamento radiativo para os aerossóis de cada origem. Com isso, fica claro o papel da absorção de radiação para o forçamento radiativo no TOA, mostrando que aerossóis que têm menor capacidade de absorção são mais eficientes para alterar o balanço de radiação no espectro solar no TOA. Chou \& Zhao estimaram o fluxo solar descendente em superfície em região tropical do Pacífico com céu claro em 308 $\mathrm{W} / \mathrm{m}^{2}$ na média. Se assumirmos este mesmo valor para região tropical no Atlântico, a qual corresponde este estudo, temos que a eficiência radiativa dos aerossóis do Saara no TOA tem valores de por volta de $10 \%$ do fluxo solar médio descendente em superfície com céu claro. Considerando que, na ocorrência de plumas mais intensas, os valores de AOD chegam a ser superiores a 4 e que a eficiência de forçamento radiativo em superfície, que não foi estimada neste estudo, é maior do que no TOA, é possível ter uma noção do tamanho do impacto deste tipo de evento no balanço de radiação.

Além da diferença da eficiência diária de forçamento dos aerossóis de cada origem, em cada etapa do transporte, também chama a atenção a variação sazonal. Já foi discutida a importância do ângulo zenital solar para os processos de interação radiação-aerossol. Porém a variação diurna do ângulo zenital solar depende do dia do ano e da localização geográfica, assim, a variação da eficiência de forçamento entre um mês e outro é esperada. Em se tratando de localização geográfica, a utilização dos valores médios de latitude e longitude é um fator que pode afetar diretamente as estimativas. Considerando isso, foi avaliada a sensibilidade das estimativas à variação da latitude e longitude. A figura 55 mostra a estimativa de eficiência diária de forçamento radiativo para os aerossóis do norte de Mali, utilizando diferentes valores de latitude e longitude. 
Eficiência diária de forçamento radiativo em diferentes coordenadas Aerossóis de Mali, etapa 1 (lat média $=15 \mathrm{~N}$, lon média $=19 \mathrm{~W}$ )

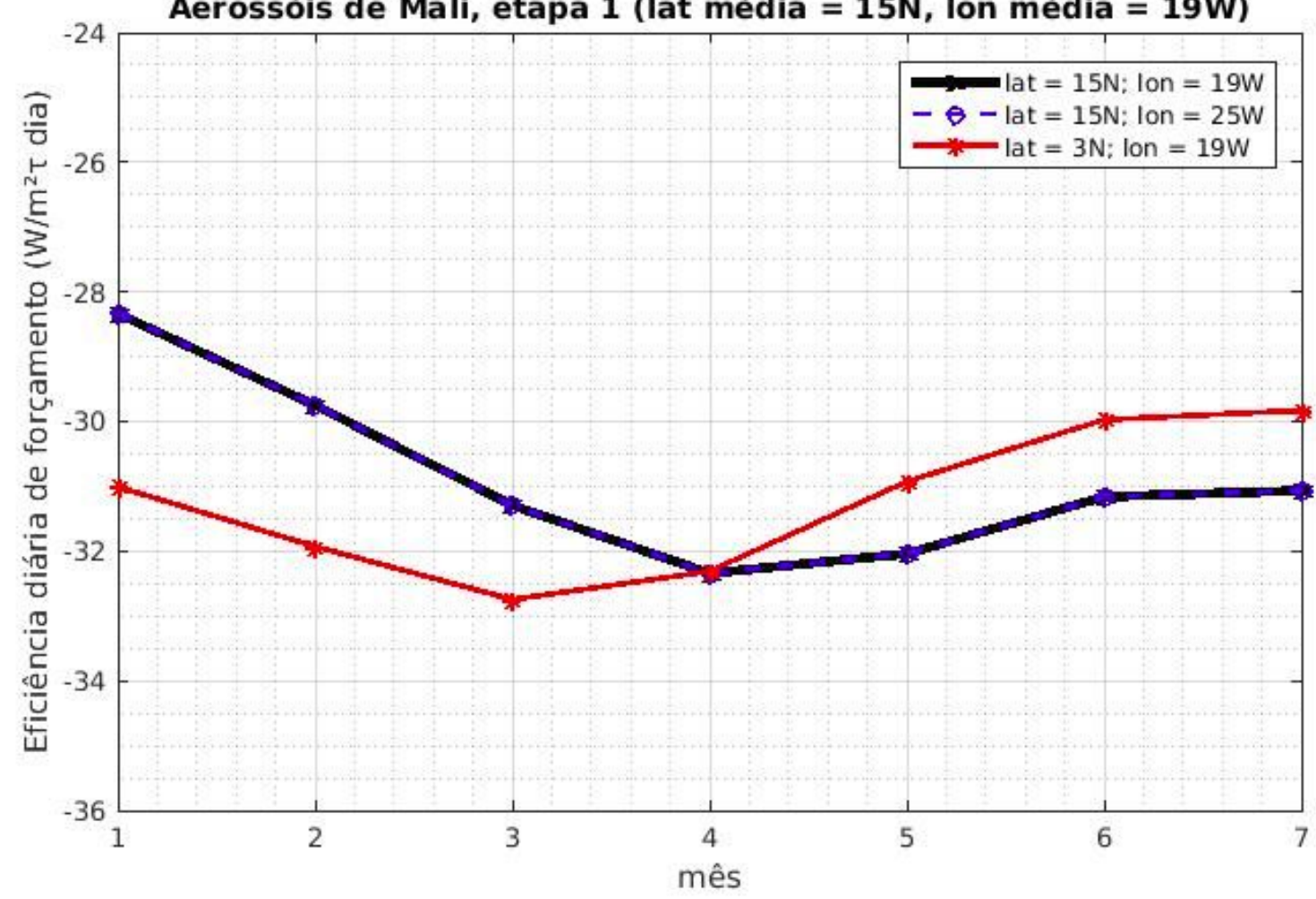

Figura 55 - Eficiência diária de forçamento radiativo para os aerossóis de Mali com diferentes coordenadas.

Observa-se que a variação de longitude não resulta em mudança alguma nas estimativas. Entretanto, a latitude se mostra como um fator de grande importância para a eficiência diária de forçamento radiativo, resultando numa mudança de até 3 $\mathrm{W} /\left(\mathrm{m}^{2}\right.$ т dia) em janeiro. Isso está associado ao movimento aparente do sol, que pode ser mostrado através da declinação do sol. Em março acontece o equinócio, quando o movimento aparente do sol faz com que o astro atravesse a linha do Equador e "mude de hemisfério", do hemisfério sul para o hemisfério norte. Neste mês o ângulo zenital solar apresenta maior variação ao longo do dia, incluindo valores em torno de $0^{\circ}$, em regiões mais próximas do equador, como o ponto de $3^{\circ} \mathrm{N}$ mostrado na figura 55. Com o deslocamento aparente do sol rumo a latitudes mais elevadas, o astro cobre uma maior quantidade de valores do ângulo zenital durante o dia na latitude de $15^{\circ} \mathrm{N}$ nos meses que se seguem, que é quando se observam os máximos da eficiência diária de forçamento radiativo. Isso indica que os aerossóis originários do deserto do Saara são mais eficientes no forçamento radiativo nos 
meses em que a geometria do sol cobre uma maior quantidade de valores de ângulo zenital durante o dia, o que corresponde aos meses de primavera na região por onde as plumas são transportadas. Fica claro também que esse efeito sazonal observado é diminuído em menores latitudes, logo, é esperado que aumente em latitudes mais elevadas, como é o caso de aerossóis do deserto transportados para o mar Mediterrâneo.

O forçamento radiativo médio diário foi calculado para dois cenários: o FRA médio diário para todos os dias dos 18 anos observados na etapa 1, e o FRA médio diário para as etapas 1 e 2 em dias com evento significativo de transporte de aerossóis utilizado neste estudo. Para o primeiro dos dois cenários calculou-se a AOD média mensal das mais de 6000 passagens do satélite Terra, e a figura 56 mostra os valores encontrados, onde é possível observar que, em média, os meses de março e junho foram os que apresentaram os maiores valores de AOD.

\section{AOD média mensal de 2001 a 2018 na etapa 1}

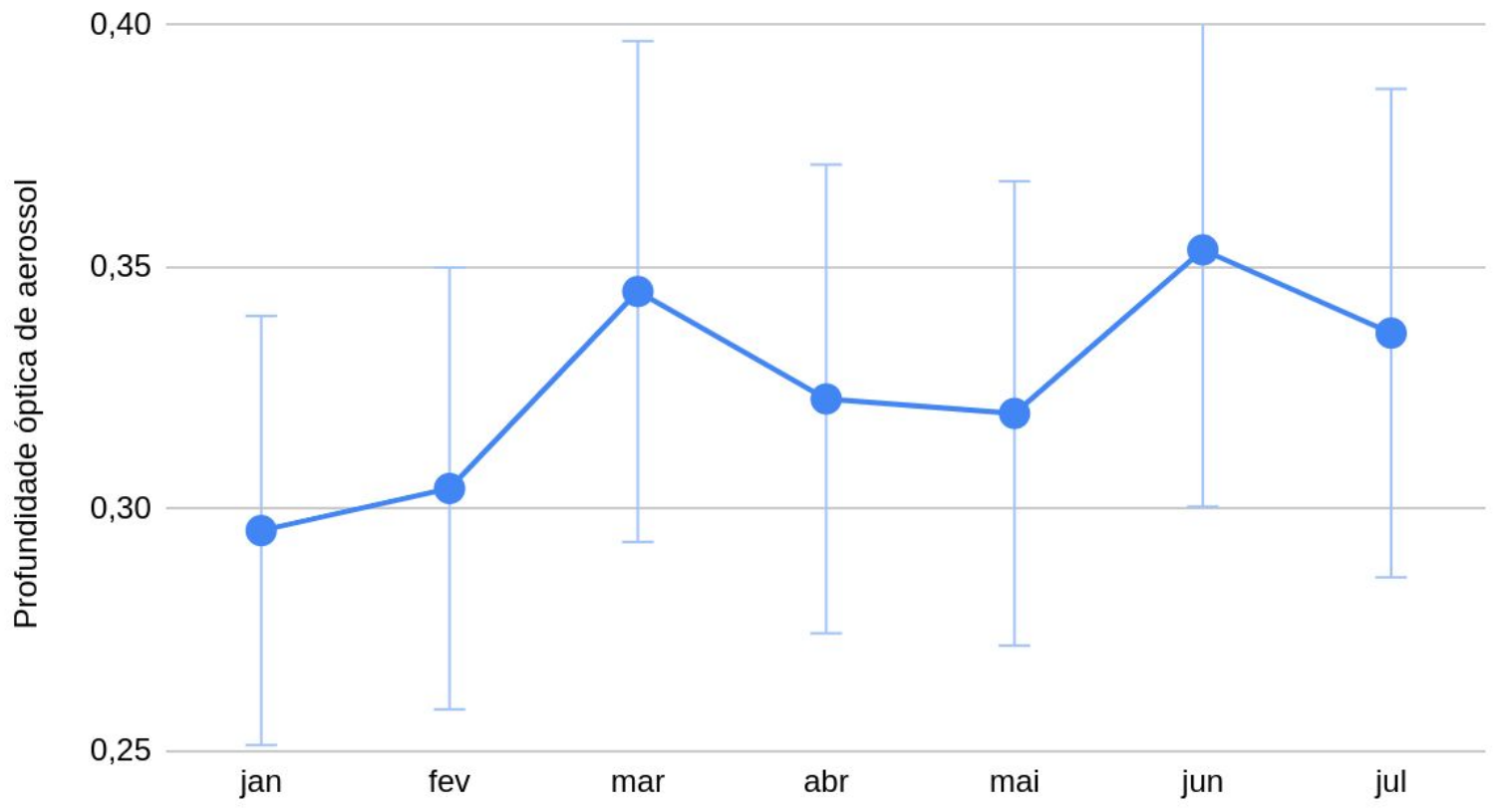

Figura 56 - AOD média mensal para todos os dias de 2001 a 2018 na etapa 1.

Posteriormente a AOD média mensal de cada mês foi multiplicada pela eficiência diária de forçamento radiativo para os aerossóis de cada origem. Os resultados são estimativas do FRA médio diário para um dia qualquer sob presença de aerossóis de cada uma das origens. Segundo Duncan et al. (2003) presença de 
aerossóis originados de queima de biomassa na região ainda é alta entre janeiro e fevereiro e nos meses seguintes diminui, sendo quase nula a partir de abril, quando os aerossóis de maior importância são a areia do deserto e sal marinho. Contudo, no cálculo da AOD média mensal com todos os 18 anos de dados não foi feita a identificação da origem do aerossol ali presente. Então os valores mostrados representam o FRA médio diário considerando a presença exclusiva de areia do deserto de cada uma das duas origens discutidas neste trabalho. Para uma estimativa mais precisa seria necessária a identificação da origem dos aerossóis presentes em cada um dos dias, com dados, no período de 18 anos, procedimento este que não foi feito neste trabalho.

\section{Forçamento radiativo médio diário na etapa 1 para todos os dias entre 2001 e 2018}

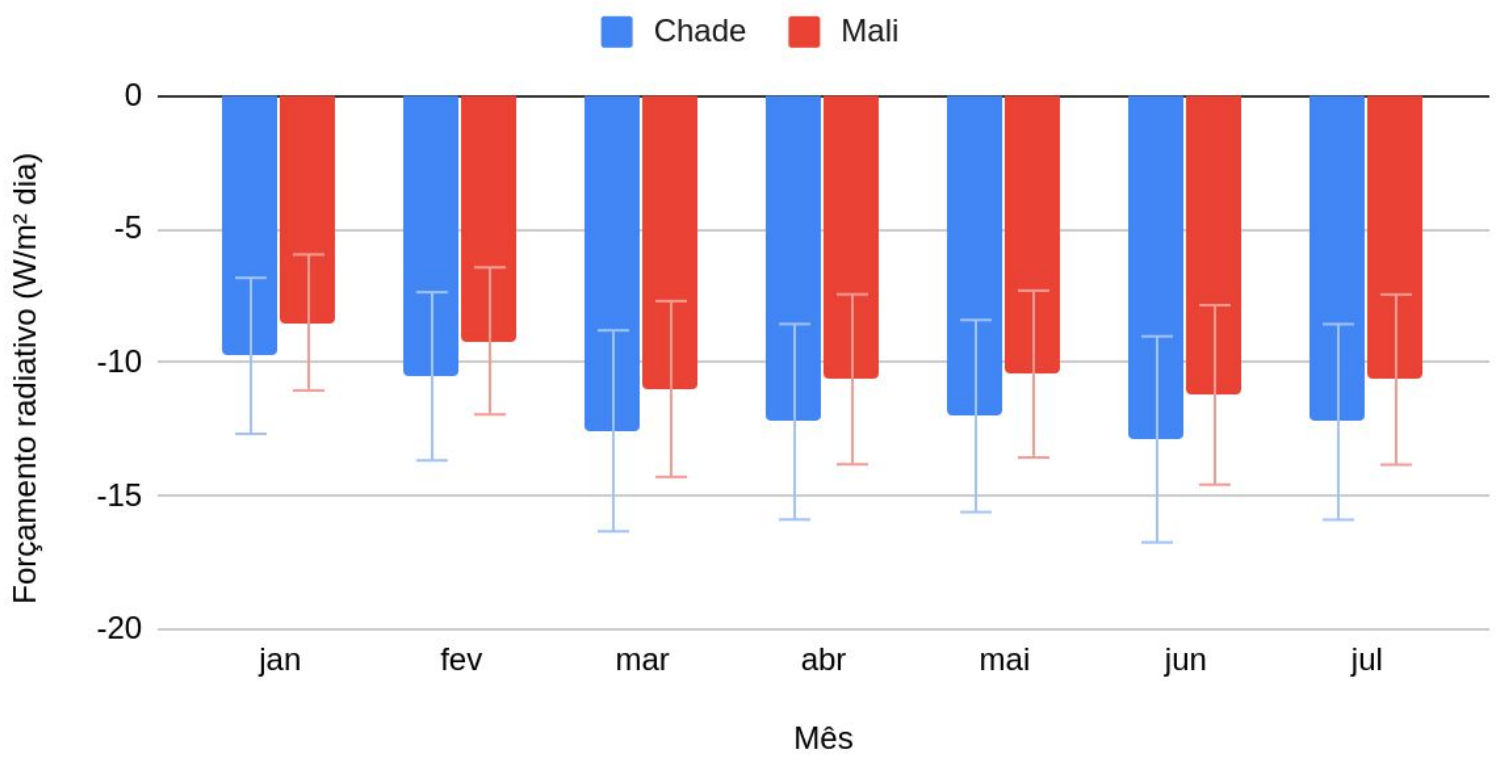

Figura 57 - Forçamento radiativo médio diário de aerossóis de cada uma das origens de janeiro a julho, utilizando AOD média mensal para cada um dos meses em questão entre 2001 e 2018.

Dentre os meses apresentados, o FRA médio diário é maior em junho, quando é de $-12,8 \pm 4 \mathrm{~W} / \mathrm{m}^{2}$ dia considerando aerossóis de Bodelé e de $-11,2 \pm 4$ $\mathrm{W} / \mathrm{m}^{2}$ dia considerando aerossóis do norte de Mali. Em janeiro esses valores são respectivamente $-9,7 \pm 3 \mathrm{~W} / \mathrm{m}^{2}$ dia e $-8,5 \pm 3 \mathrm{~W} / \mathrm{m}^{2}$ dia. A diferença entre os resultados de cada origem não é maior que $2 \mathrm{~W} / \mathrm{m}^{2}$ em nenhum dos meses mostrados. 
A AOD média de janeiro a julho na região mostrou uma leve tendência de aumento no período de 2001 a 2018, como pode ser observado na figura 58. 2012 e 2015 foram os anos que apresentaram valores de AOD mais elevados no período do ano analisado. Uma vez que o FRA médio diário depende diretamente da AOD, essa leve tendência de aumento deve também ser refletida nessa variável.

\section{AOD média de janeiro a julho na etapa 1}

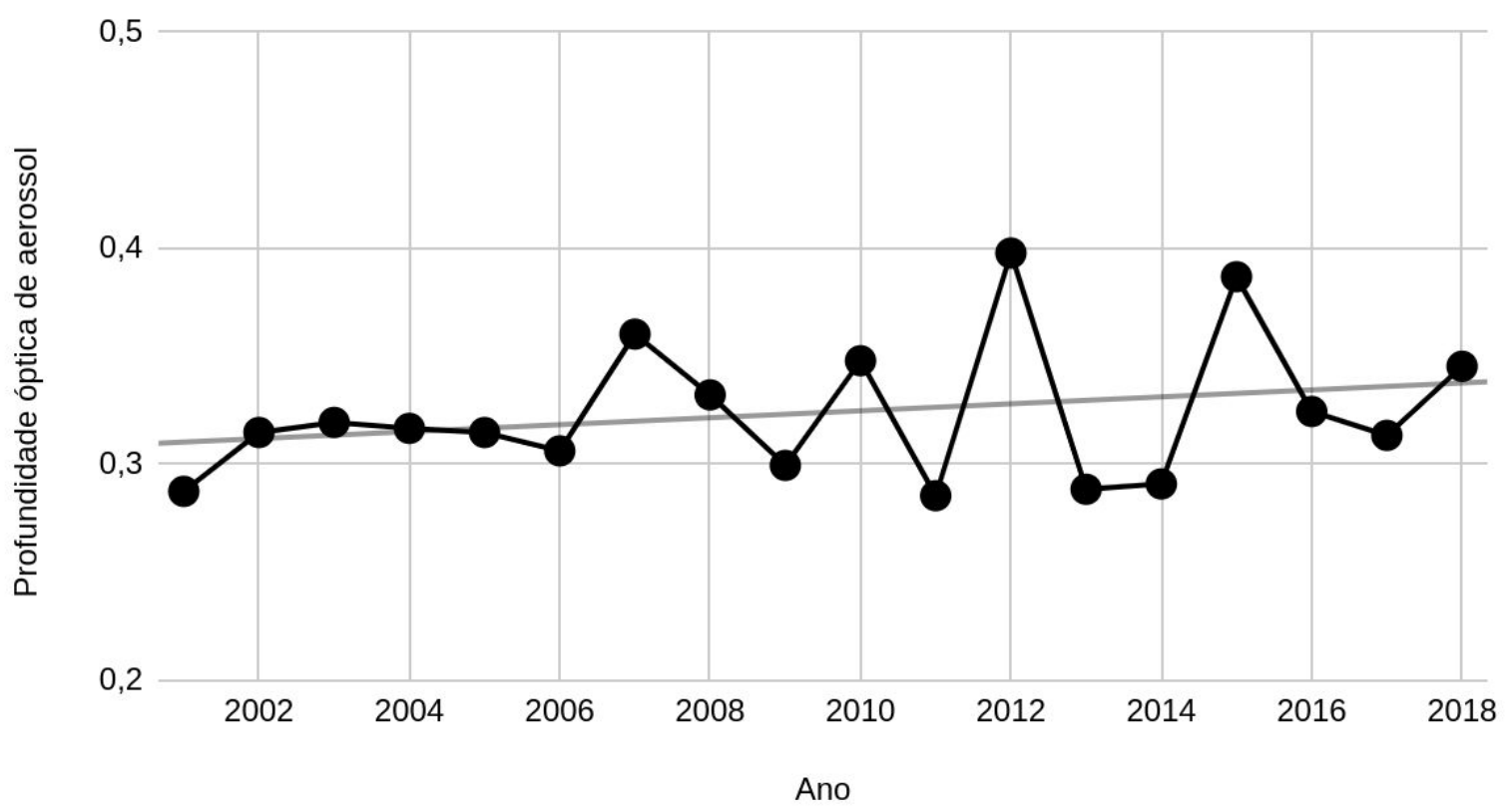

Figura 58 - AOD média de janeiro a julho na etapa 1 para os anos de 2001 a 2018.

A AOD média mensal foi usada para calcular o FRA médio diário para cada um dos meses de janeiro a julho de 2001 a 2018, assumindo um cenário com aerossóis de cada uma das origens. As figuras de 59 e 62 mostram os valores encontrados e as diferenças para as estimativas para todo o período, apresentadas na figura 57 . 
FRA médio diário para aerossóis de Bodelé na etapa 1
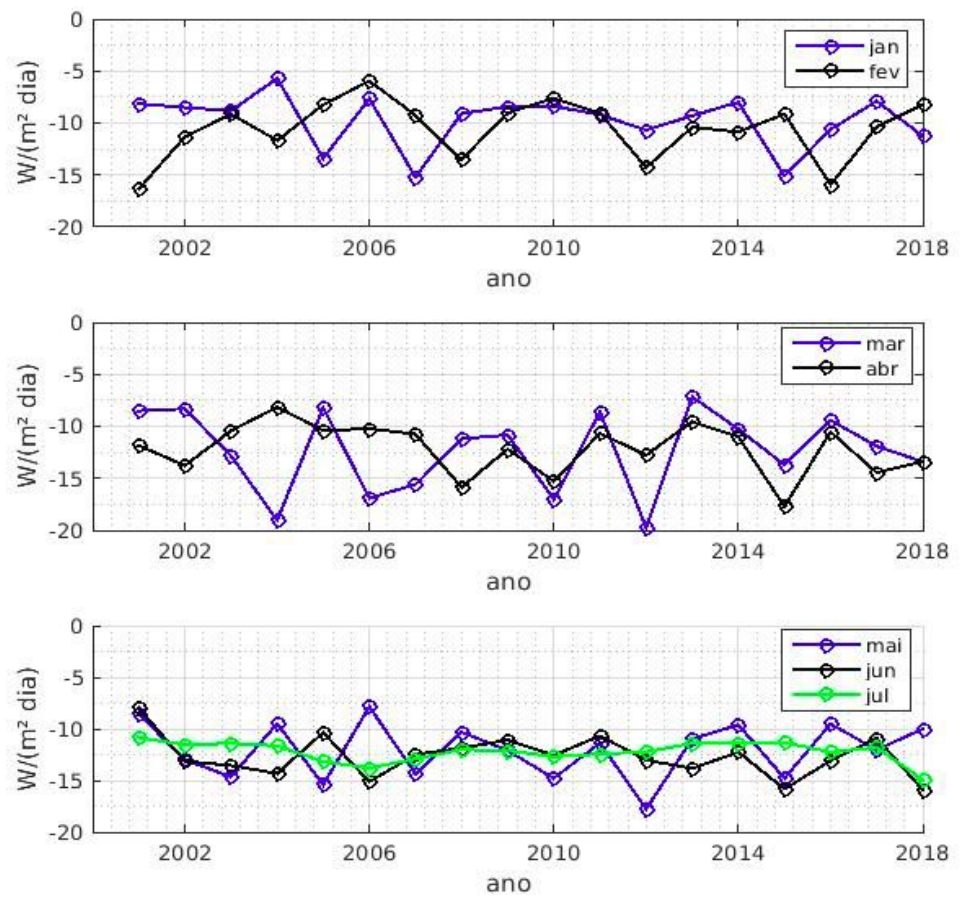

Figura 59 - FRA médio diário para um cenário com apenas aerossóis de Bodelé para os meses de a) janeiro e fevereiro; b) março e abril; c) maio, junho e julho de 2001 a 2018.
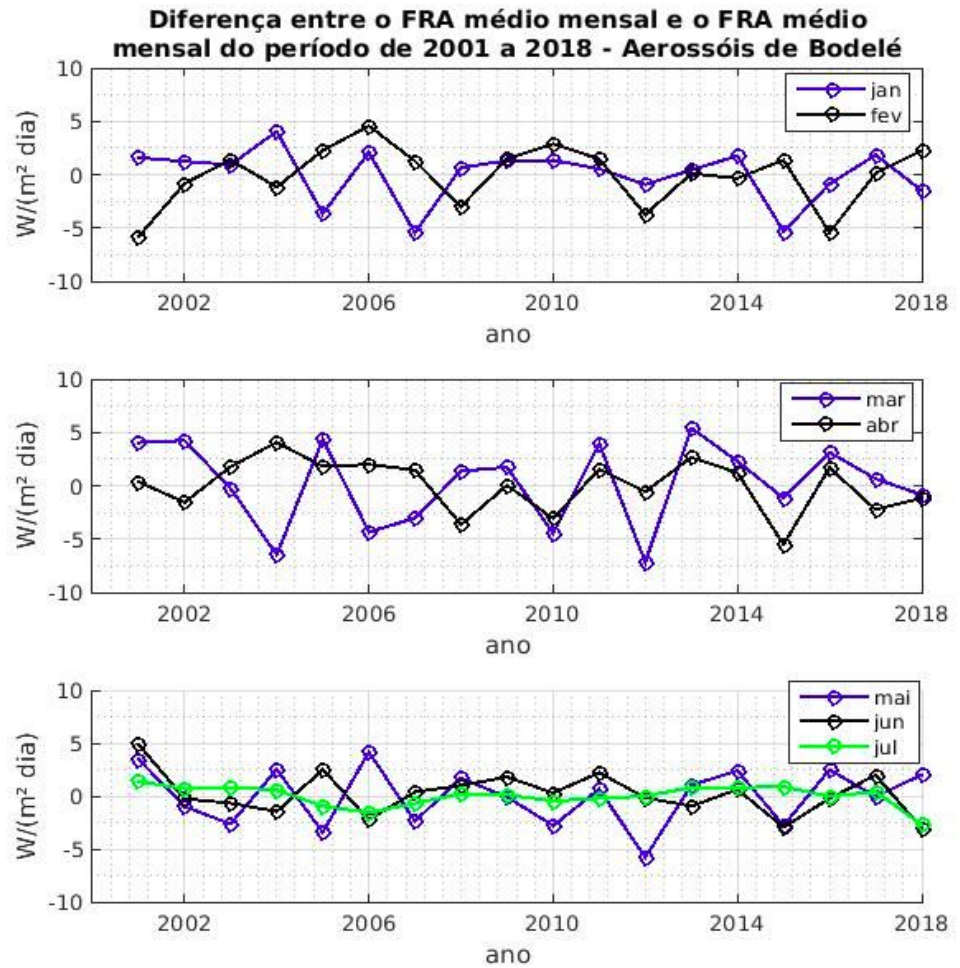

Figura 60 - Diferença do FRA médio diário de cada mês para todo o valor médio mensal de todo o período (apresentado na figura 57): cenário com aerossóis de Bodelé. a) janeiro e fevereiro; b) março e abril; c) maio, junho e julho de 2001 a 2018. 

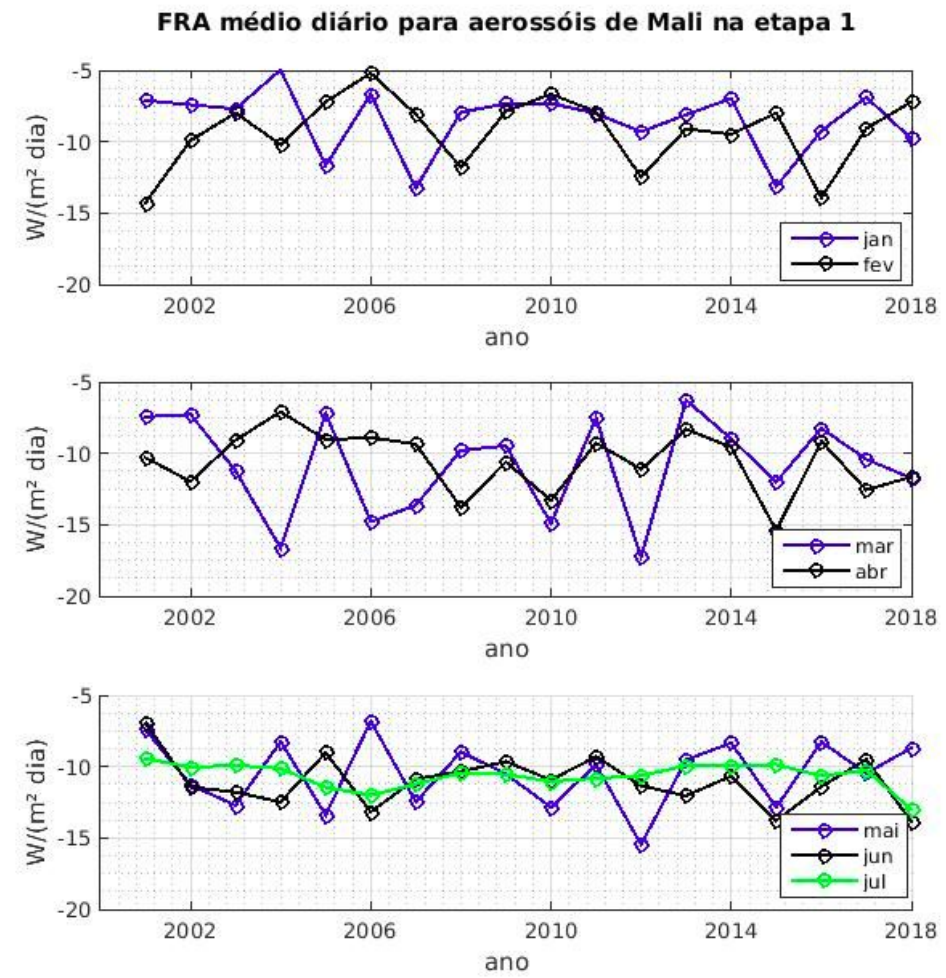

Figura 61 - FRA médio diário para um cenário com apenas aerossóis de Mali para os meses de a) janeiro e fevereiro; b) março e abril; c) maio, junho e julho de 2001 a 2018.
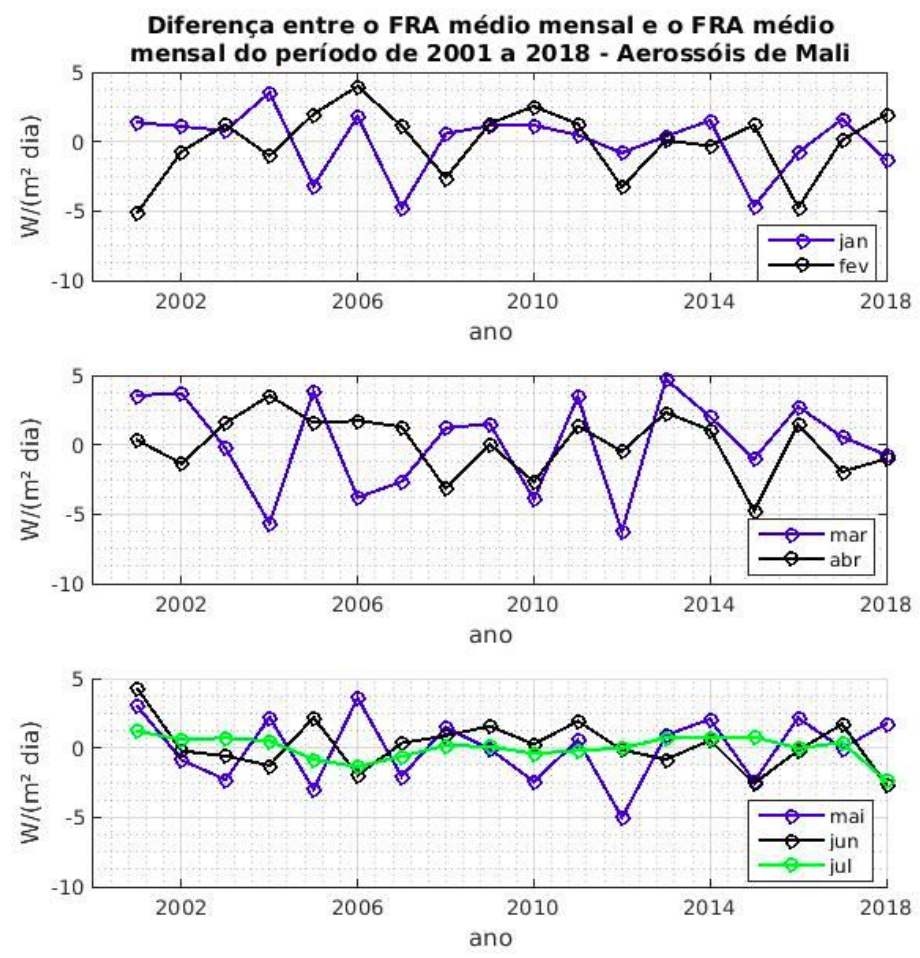

Figura 62 - Diferença do FRA médio diário de cada mês para todo o valor médio mensal de todo o período (apresentado na figura 57): cenário com aerossóis de Mali. a) janeiro e fevereiro; b) março e abril; c) maio, junho e julho de 2001 a 2018. 
Através das figuras é possível observar as variações anuais de AOD refletidas no FRA médio diário para cada um dos meses. Chama atenção o ano de 2012, que teve a maior AOD média anual, e teve FRA médio diário acima da média (em valores absolutos) em todos os meses apresentados. Março de 2012 teve o maior FRA médio diário de todo o período, com valor aproximadamente $80 \%$ acima da média para esse mês. Neste ano, todos os meses tiveram FRA médio diário acima da média. Apesar de alguns valores extremos, os gráficos mostram que em aproximadamente $90 \%$ dos meses o FRA médio diário estimado não diferiu mais que $50 \%$ das médias estimadas para todo o período (figura 57 ). Os meses de junho e julho, respectivamente primeiro e terceiro mês com maior AOD, também foram os meses com menor variabilidade na AOD e FRA médio diário dentro do período de 2001 a 2018. Os dois meses estão dentro do período apontado por Liu et al. (2012) como a época de maior emissão de areia na depressão de Bodelé.

Para o segundo cenário de FRA médio diário foi utilizada a AOD média diária nas etapas 1 e 2 de dias que estiveram compreendidos nos eventos de transporte utilizados neste estudo. Para este cenário é considerada a origem de cada evento de transporte. As figuras 63 e 64 mostram os resultados do FRA médio diário para este cenário. Observa-se que quando ocorrem eventos significativos de transporte de aerossóis originários do norte de Mali o FRA médio diário na etapa 1 é aproximadamente o triplo do que é observado na média de todos os dias. Quando a origem dos aerossóis é a depressão de Bodelé, aquele valor chega a quadruplicar. 
Forçamento radiativo médio diário para os dias com evento de transporte (Aerossóis de Bodelé)

etapa $1 \square$ etapa 2

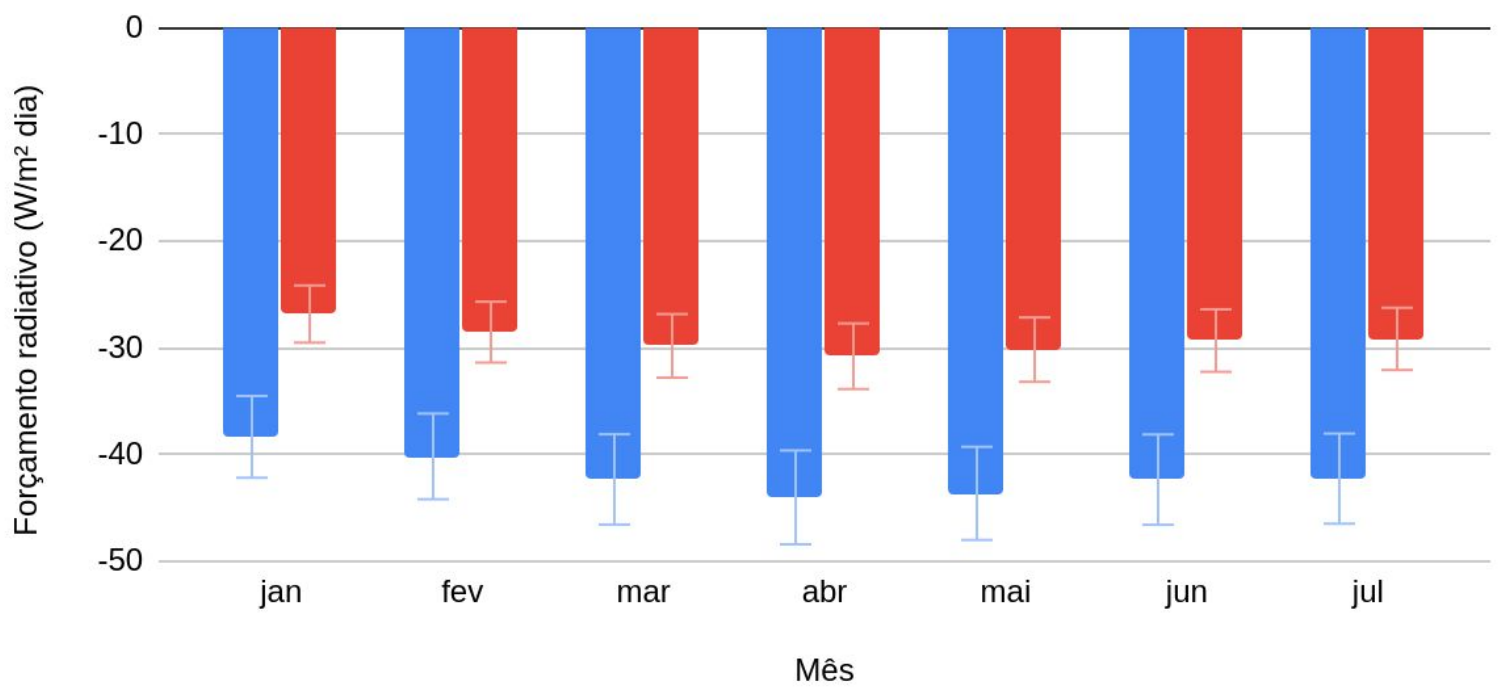

Figura 63 - Forçamento radiativo médio diário em dias com evento de transporte de aerossóis originários de Bodelé.

Forçamento radiativo médio diário para os dias com evento de transporte (Aerossóis de Mali)

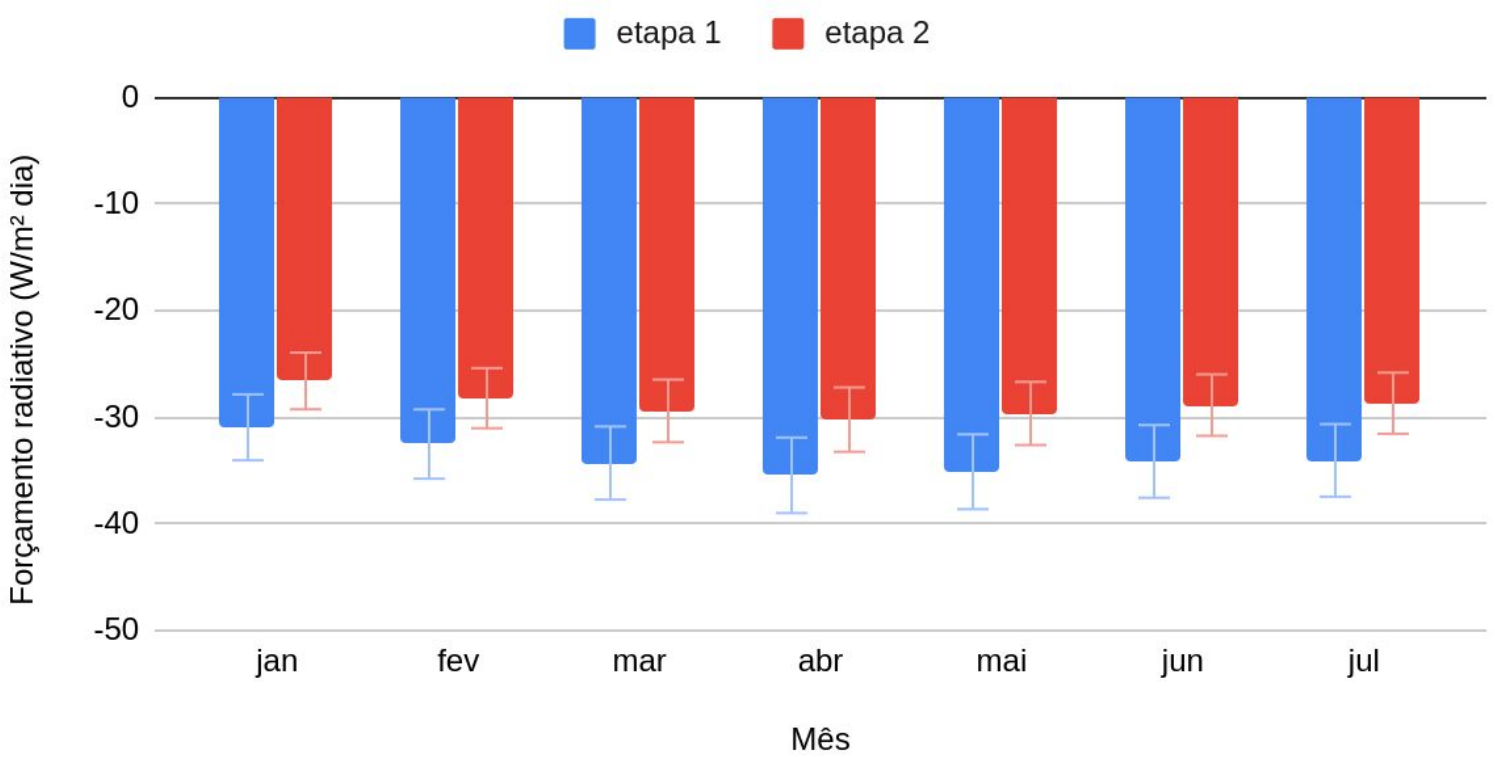

Figura 64 - Forçamento radiativo médio diário em dias com evento de transporte de aerossóis originários de Mali. 
É possível observar que para os eventos originários de Bodelé a diferença entre as etapas 1 e 2 fica mais clara, com o forçamento radiativo médio diário sendo até $30 \%$ menor ( $13 \mathrm{~W} / \mathrm{m}^{2}$ dia em valores absolutos) na segunda etapa nos meses de maio, junho e julho. Por sua vez, para os eventos originários em Mali essa diferença é de 15\% ( $6 \mathrm{~W} / \mathrm{m}^{2}$ dia em valores absolutos) para os mesmos meses. Isso se dá em grande parte pela variação na AOD durante o transporte de cada origem. Entre a etapa 1 e a etapa 2 a AOD dos eventos de Chade diminuiu, em média, de 1,16 para 0,86 , enquanto que nos eventos originados em Mali essa redução foi de apenas de 1,07 para 0,95 .

Baseado na diminuição da eficiência de forçamento radiativo, associado à diminuição do albedo simples, e na diminuição da $A O D$ é possível projetar o forçamento radiativo das plumas que avançam até a Amazônia. Como já dito, a AOD média das plumas que chegaram à costa da América do Sul foi de 0,63 e 0,65 para eventos vindos de Bodelé e de Mali respectivamente. Se a eficiência fosse conservada entre as etapas 2 e 3 , o forçamento radiativo médio diário destas plumas variaria de $-20 \pm 2 \mathrm{~W} / \mathrm{m}^{2}$ dia em janeiro a $-23 \pm 3 \mathrm{~W} / \mathrm{m}^{2}$ dia em abril para os aerossóis de Chade, e de $-18 \pm 2 \mathrm{~W} / \mathrm{m}^{2}$ dia a $-20 \pm 2 \mathrm{~W} / \mathrm{m}^{2}$ dia para os aerossóis do oeste africano. Baseado nisso, é possível projetar que o forçamento radiativo médio diário das plumas quando chegam à Amazônia representa não mais do que $60 \%$ do forçamento radiativo médio diário destas mesmas plumas quando deixam o continente africano. O valor exato, entretanto, pode ser representativamente menor devido à tendência de diminuição do albedo simples das plumas e as mudanças na estrutura das mesmas.

Após todas as estimativas, os eventos mais significativos de transporte de aerossóis de cada origem foram analisados de forma a visualizar o comportamento espacial do forçamento radiativo médio diário para casos individuais de transporte. Estes eventos foram o de 21 de março de 2010 para aerossóis de Bodelé, e de 29 de abril de 2012 para aerossóis de Mali. O forçamento radiativo médio diário foi calculado para diferentes dias dos eventos, utilizando a eficiência diária de forçamento radiativo e a AOD com resolução de $1^{\circ} \times 1^{\circ}$ do MODIS, atrelado ao produto CERES-SSF-1deg. Nas figuras 65 a 67 são apresentadas as estimativas para o evento originário de Bodelé. No dia 24 de março algumas regiões próximas à 
costa africana mostram valores maiores (em módulo) que $-100 \mathrm{~W} / \mathrm{m}^{2}$ dia. Nos outros dias observa-se que na chegada à América do Sul, estes valores não superam em módulo os $30 \mathrm{~W} / \mathrm{m}^{2}$ dia.

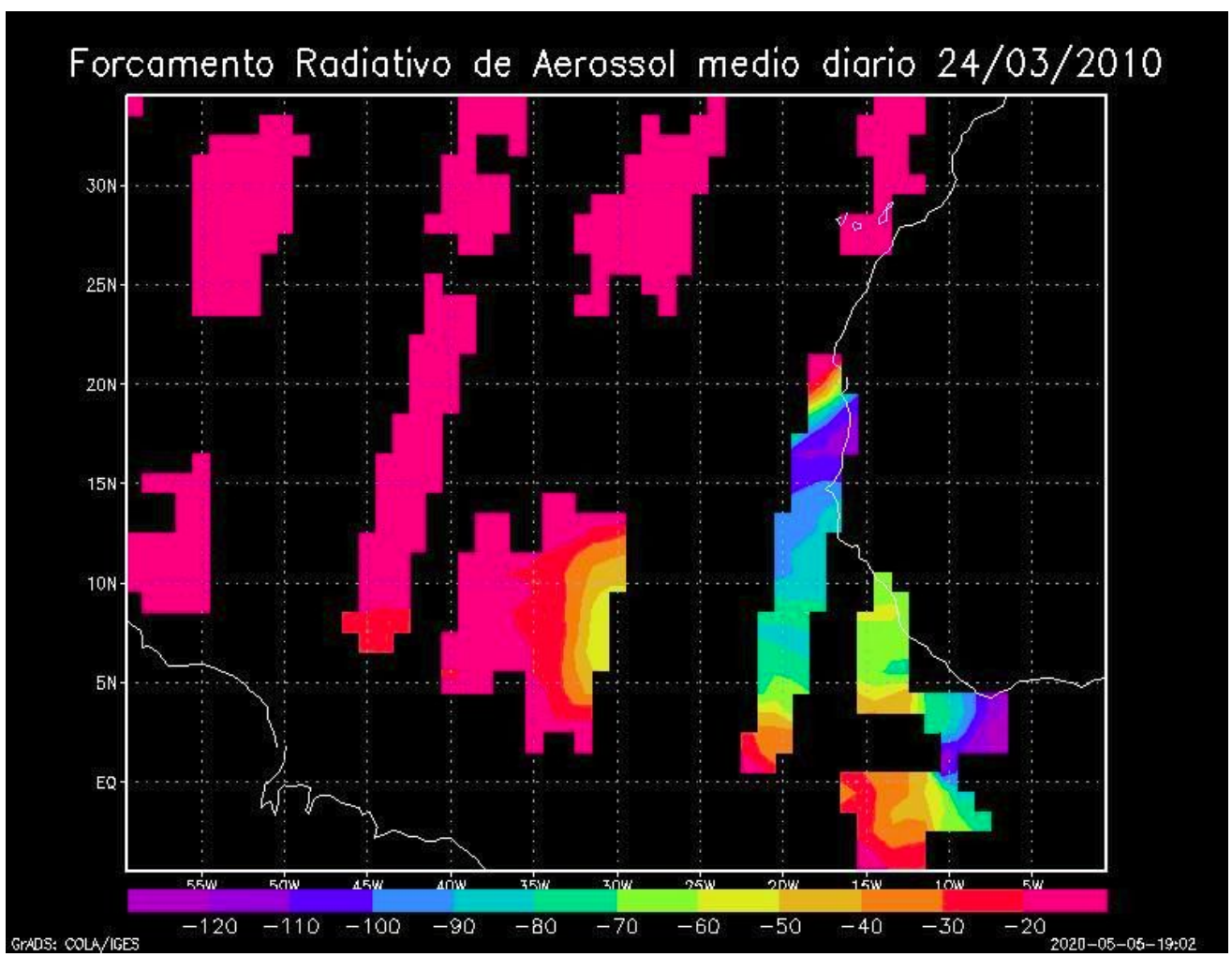

Figura 65 - Forçamento Radiativo de Aerossol médio diário em 24 de março de 2010. Escala em $\mathrm{W} / \mathrm{m}^{2}$ dia. Regiões no extremo de $-20 \mathrm{~W} / \mathrm{m}^{2}$ dia indicam a inexistência de aerossóis do deserto do Saara. 


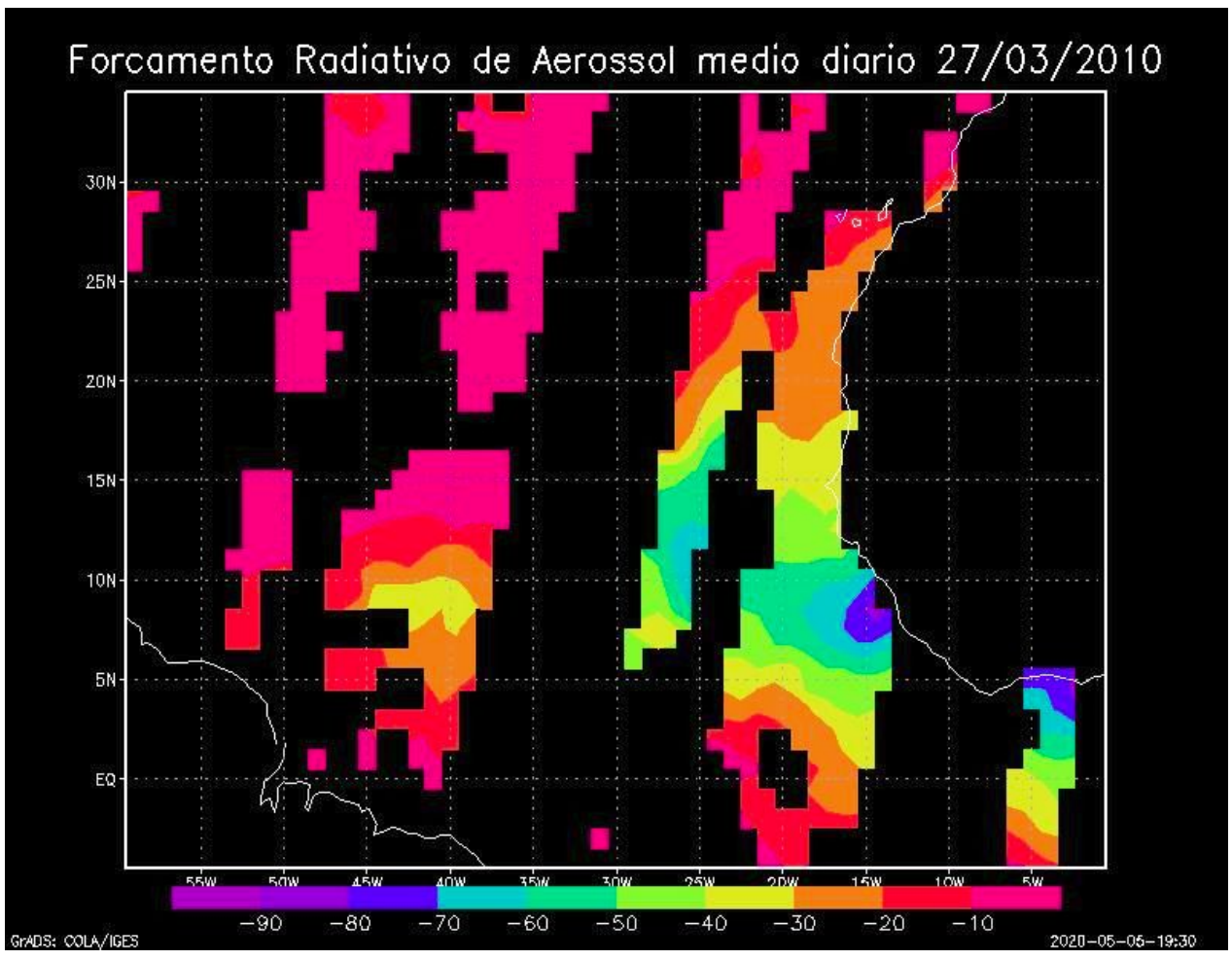

Figura 66 - Forçamento Radiativo de Aerossol médio diário em 27 de março de 2010. Escala em $\mathrm{W} / \mathrm{m}^{2}$ dia. Regiões no extremo de $-10 \mathrm{~W} / \mathrm{m}^{2}$ dia indicam a inexistência de aerossóis do deserto do Saara.

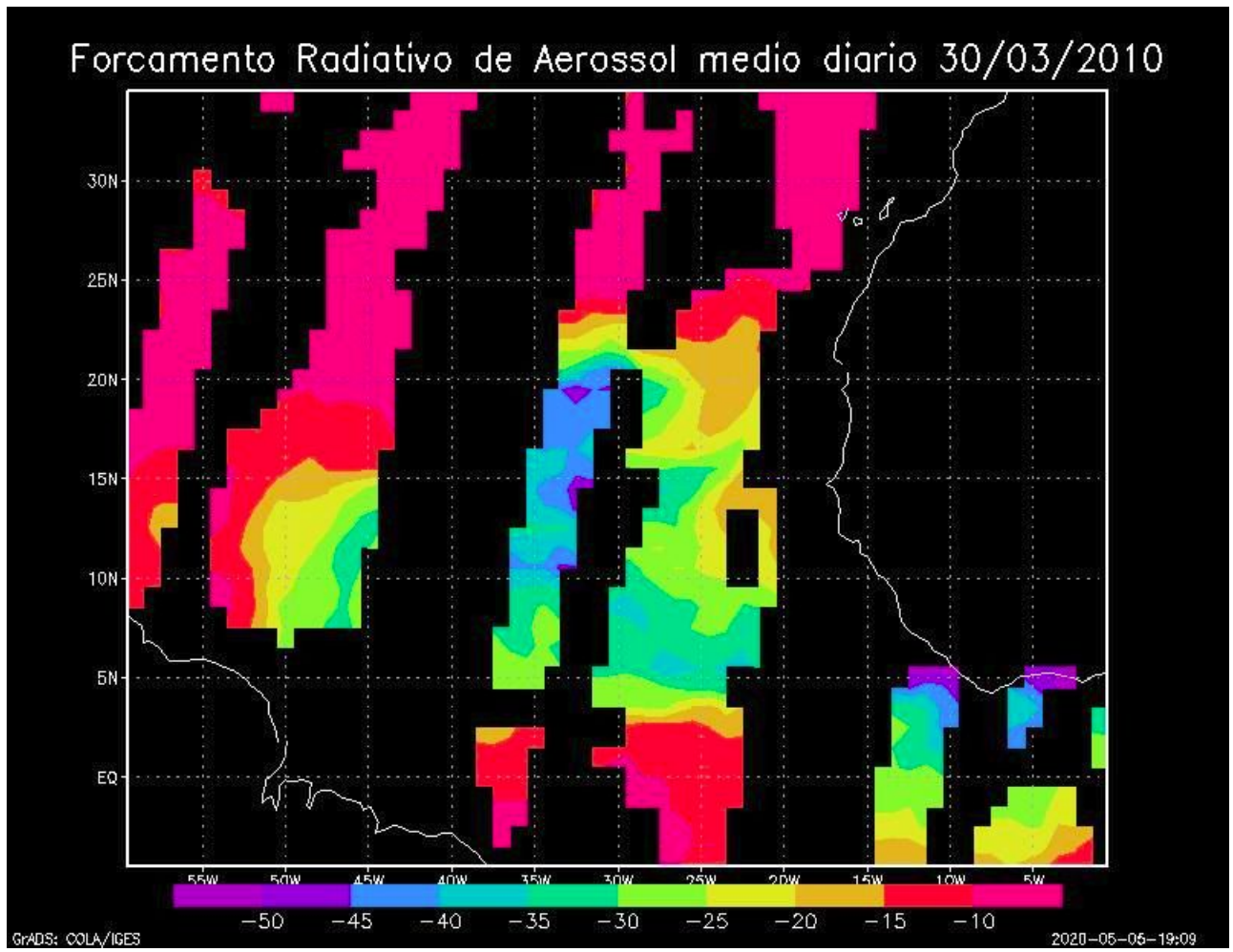

Figura 67 - Forçamento Radiativo de Aerossol médio diário em 30 de março de 2010. Escala em $\mathrm{W} / \mathrm{m}^{2}$ dia. Regiões no extremo de $-10 \mathrm{~W} / \mathrm{m}^{2}$ dia indicam a inexistência de aerossóis do deserto do Saara. 
As figuras dão também uma dimensão da extensão da área sob a influência de aerossóis. No dia 24 de março, a área dessa região era superior a $600000 \mathrm{~km}^{2}$. O evento originário de Mali teve dimensão menor, com cerca de $400000 \mathrm{~km}^{2}$ no dia 01 de maio. O FRA médio diário dos aerossóis desta origem também foi menor que o do outro evento, decaindo também rapidamente na região correspondente à etapa 2. As figuras 68 e 69 mostram estes resultados.

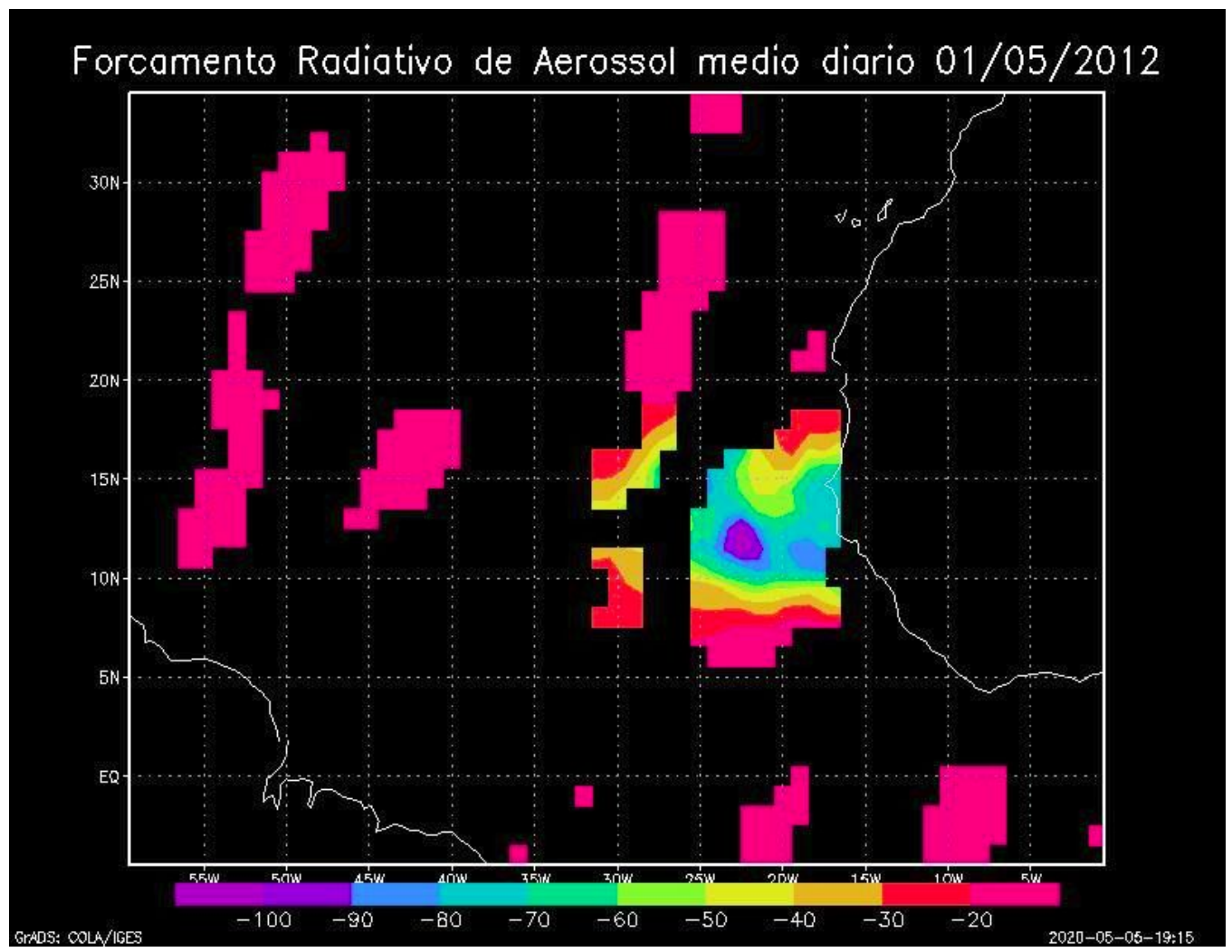

Figura 68 - Forçamento Radiativo de Aerossol médio diário em 01 de maio de 2012. Escala em W/m² dia. Regiões no extremo de $-20 \mathrm{~W} / \mathrm{m}^{2}$ dia indicam a inexistência de aerossóis do deserto do Saara. 


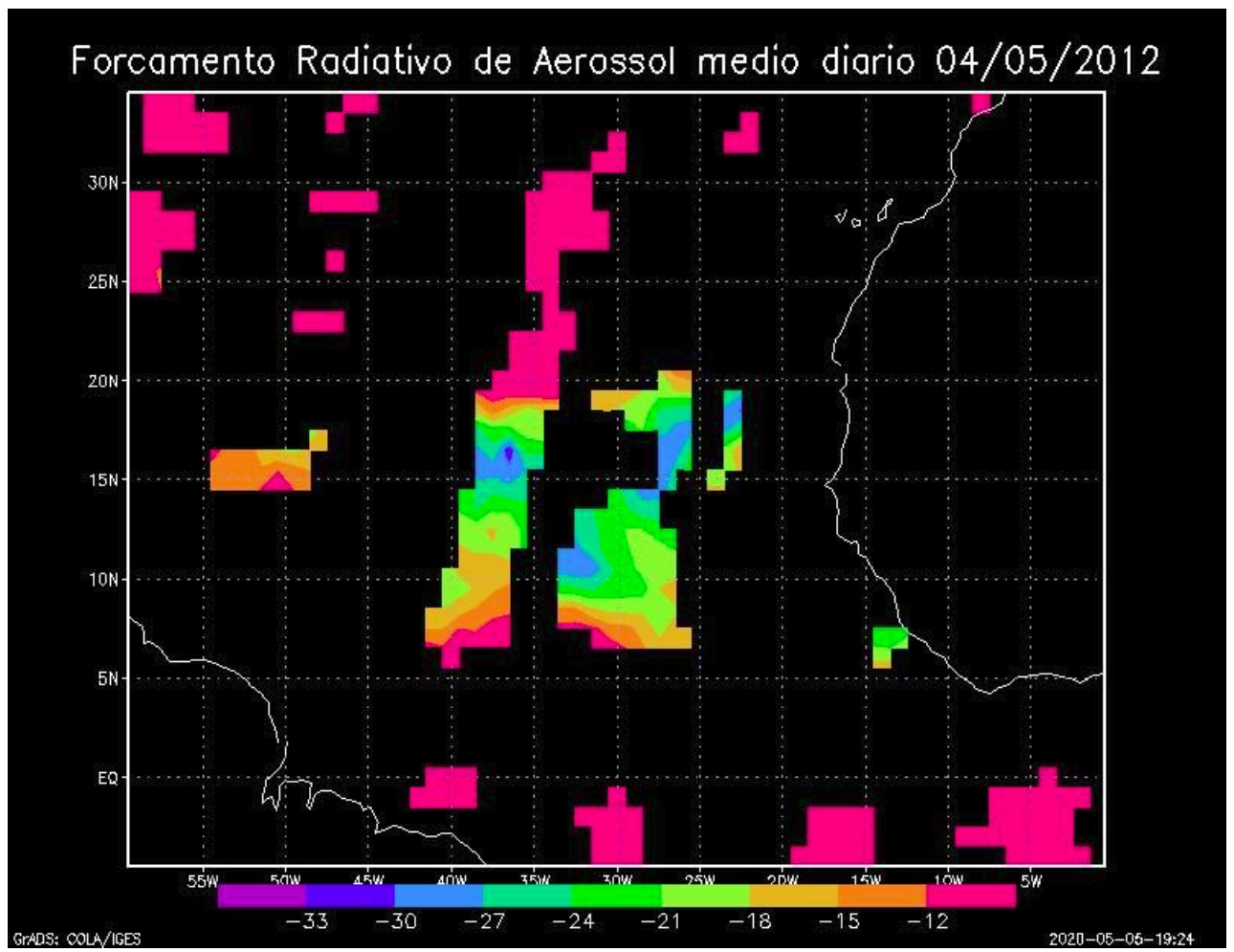

Figura 69 - Forçamento Radiativo de Aerossol médio diário em 04 de maio de 2012. Escala em W/m² dia. Regiões no extremo de $-12 \mathrm{~W} / \mathrm{m}^{2}$ dia indicam a inexistência de aerossóis do deserto do Saara.

Estes são casos isolados, porém que ilustram bem a diferença entre o impacto dos aerossóis de cada uma das origens no saldo de radiação no TOA. Os eventos de transporte de aerossóis originados no norte do Chade são mais eficientes no forçamento radiativo, e também são mais eficientes no transporte de aerossóis em si. Com isso, têm um impacto no balanço de radiação mais ressaltado que os eventos de transporte que se originam no norte de Mali. 
Capítulo 5: Conclusões e Perspectivas 
O objetivo principal deste trabalho era investigar o impacto do transporte de aerossóis do deserto do Saara no balanço de radiação no seu caminho entre a África e a Amazônia, e identificar padrões associados a estes eventos. Para isso foram utilizados os produtos de fluxo radiativo do projeto CERES/NASA e modelagem computacional através do código de transferência radiativa LibRadtran.

Através da análise e classificação dos eventos de transporte foi possível identificar, além da depressão de Bodelé, no norte do Chade, (Washington \& Todd, 2005; Koren et al., 2006; Washington et al., 2006), uma outra região de onde se originou grande parte das plumas de aerossóis, localizada entre o norte de Mali e Mauritânia, e o sul da Argélia, já documentada em diversos trabalhos (Chiapello et al., 1997; Middleton \& Goudie, 2001; Gläser et al., 2015). A identificação dessa região como origem para grande parte dos eventos de transporte de aerossóis destaca a importância das configurações atmosféricas na África ocidental para o levantamento de areia do deserto do Saara, da mesma forma que no norte do Chade se tem o jato de baixos níveis de Bodelé (Washington \& Todd, 2005).

A análise do forçamento radiativo instantâneo, representado pela diferença entre os fluxos observacionais do CERES e os fluxos de uma cena "limpa", foi usada para investigar os padrões de forçamento radiativo em superfície, atmosfera e no TOA, no espectro solar e terrestre. Os resultados mostraram que o forçamento no espectro terrestre representa, em média, entre $3 \%$ e $13 \%$ do forçamento radiativo no espectro solar, e não apresenta padrão característico associado a uma maior ou menor presença de aerossóis, como existe no forçamento radiativo no espectro solar no TOA. Isso indica que possivelmente a radiação no espectro terrestre é mais afetada por outros fatores do que pelo aerossol em si. Foi observado também que, no espectro solar, o forçamento radiativo é maior em superfície do que no TOA, ambos sendo negativos, representando um déficit no saldo radiativo, enquanto que na atmosfera o forçamento é positivo, mostrando um superávit no saldo de radiação.

$\mathrm{O}$ forçamento radiativo também mostrou que há uma relação linear entre a profundidade óptica de aerossol e o forçamento radiativo de aerossol no topo da atmosfera. Mas através das medidas instantâneas do fluxo radiativo não foi possível identificar diferença estatisticamente significativa entre a eficiência de forçamento radiativo dos aerossóis de cada uma das origens. 
No entanto, a estimativa da eficiência diária de forçamento radiativo evidenciou diferenças entre os aerossóis de cada origem. Primeiramente, o albedo simples utilizado nas simulações, realizadas para extrapolar as irradiâncias ascendentes no TOA para todas as geometrias do sol, que resultaram no melhor ajuste aos resultados observados mostrou uma maior capacidade de absorção no espectro solar pelos aerossóis originários de Mali, com albedo simples, em $550 \mathrm{~nm}$, de 0,89 na primeira etapa do transporte e 0,88 na segunda, enquanto que para os aerossóis de Bodelé os valores foram 0,935 e 0,915. Posteriormente, a própria eficiência diária de forçamento radiativo, na qual a eficiência de forçamento radiativo é integrada do nascer ao pôr do sol, mostrou diferença estatisticamente significativa entre os resultados das duas origens. A eficiência diária de forçamento radiativo dos aerossóis originários de Bodelé na etapa 1 do transporte foi de $-33 \pm 4 \mathrm{~W} /\left(\mathrm{m}^{2} \mathrm{~T}\right.$ dia) em janeiro, tendo seu máximo em abril, quando foi de $-38 \pm 4 \mathrm{~W} /\left(\mathrm{m}^{2} \mathrm{~T}\right.$ dia), depois voltando a diminuir e sendo de $-36 \pm 4 \mathrm{~W} /\left(\mathrm{m}^{2} \mathrm{~T}\right.$ dia $)$ em julho. O resultado do mês de julho concorda com o resultado de Li et al. (2004), que encontrou para esse mês e nessa região, a eficiência diária de forçamento radiativo de $-35 \pm 4 \mathrm{~W} /\left(\mathrm{m}^{2} \mathrm{~T} \mathrm{dia}\right)$. Para os aerossóis do norte de Mali estes valores foram de $-29 \pm 3 \mathrm{~W} /\left(\mathrm{m}^{2} \mathrm{~T}\right.$ dia $)$ em janeiro, $-33 \pm 4 \mathrm{~W} /\left(\mathrm{m}^{2}\right.$ т dia) em abril e de $32 \pm 4 \mathrm{~W} /\left(\mathrm{m}^{2} \mathrm{~T}\right.$ dia $)$ em julho. Com isso conclui-se que os aerossóis destas duas origens afetam o balanço de radiação de forma diferente.

Os resultados para a etapa 2 mostram que as plumas não conservam suas propriedades ópticas durante o transporte, e consequentemente, afetam o balanço de radiação de forma diferente nas diferentes etapas do transporte. Na etapa 2 do transporte a eficiência diária de forçamento radiativo foi de $-31 \pm 4 \mathrm{~W} /\left(\mathrm{m}^{2} \mathrm{~T}\right.$ dia $),-35$ $\pm 4 \mathrm{~W} /\left(\mathrm{m}^{2} \mathrm{~T}\right.$ dia $)$ e $-34 \pm 4 \mathrm{~W} /\left(\mathrm{m}^{2} \mathrm{~T}\right.$ dia $)$ para os aerossóis originários de Bodelé, e de $-28 \pm 3 \mathrm{~W} /\left(\mathrm{m}^{2} \mathrm{~T}\right.$ dia $),-32 \pm 4 \mathrm{~W} /\left(\mathrm{m}^{2} \mathrm{~T}\right.$ dia $)$ e $-30 \pm 3 \mathrm{~W} /\left(\mathrm{m}^{2} \mathrm{~T}\right.$ dia $)$ para os aerossóis de Mali, em janeiro, abril e julho respectivamente. Baseado nestas estimativas, foi atestada diferença estatisticamente significante ao nível de confiança de 0,05 entre as eficiências das etapas 1 e 2 em ambos os casos, entretanto, variações na eficiência dentro das incertezas (que é de 10\%) podem resultar na perda de significância estatística. Estes valores foram usados para estimar o forçamento radiativo médio diário, multiplicando-os pela AOD média diária para toda a região. 
Com os resultados apresentados, conclui-se que os aerossóis de Bodelé são mais eficientes no forçamento radiativo no espectro solar no TOA que os aerossóis do norte de Mali. Conclui-se também que, conforme as plumas avançam a oeste, há uma redução significativa na eficiência diária de forçamento radiativo, que se associa aos processos de envelhecimento e de deposição dos aerossóis.

Não foi possível fazer estimativa da eficiência diária na etapa 3 , quando as plumas se aproximam da América do Sul, entretanto foi possível fazer projeções do forçamento radiativo médio diário dos aerossóis nessa região, baseado no comportamento da eficiência diária de forçamento nas etapas anteriores e na AOD média das plumas que chegaram à Amazônia. Baseado nisso, é projetado que o forçamento radiativo médio diário das plumas quando chegam à Amazônia representa não mais do que $60 \%$ do forçamento radiativo médio diário destas mesmas plumas quando deixam o continente africano (o valor exato, entretanto, pode ser representativamente menor). Contudo as observações e estimativas de qualquer efeito radiativo dos aerossóis do deserto do Saara sobre o continente sul americano ainda representam um desafio, devido à desestruturação das plumas, a presença de outras fontes de aerossol e alta densidade de nuvens sobre o continente.

Baseando-se nos resultados e conclusões deste trabalho, as perspectivas futuras neste tema são de investigações mais detalhadas dos processos físicos, químicos e dinâmicos destes aerossóis após a chegada à América do Sul, provavelmente com utilização de medições em superfície, para uma abordagem mais pontual. Projeta-se também a perspectiva de estudos que visem analisar mais detalhadamente as diferenças nas propriedades dos aerossóis de cada origem, que resultam nas diferenças de eficiência de forçamento radiativo. Bem como de trabalhos no sentido de investigar possíveis impactos da presença de areia sobre o oceano no conteúdo de vapor d'água na atmosfera. Por fim, uma abordagem importante relacionada a este tipo de evento seria o estudo dos efeitos termodinâmicos destas plumas durante o seu deslocamento. 


\section{Bibliografia}

ARTAXO, Paulo et al. Composition and sources of aerosols from the Amazon Basin. Journal of Geophysical Research: Atmospheres, v. 93, n. D2, p. 1605-1615, 1988.

ARTAXO, Paulo; GERAB, Fábio; RABELLO, Marta LC. Elemental composition of aerosol particles from two atmospheric monitoring stations in the Amazon Basin. Nuclear Instruments and Methods in Physics Research Section B: Beam Interactions with Materials and Atoms, v. 75, n. 1-4, p. 277-281, 1993.

BRISTOW, Charlie S.; HUDSON-EDWARDS, Karen A.; CHAPPELL, Adrian. Fertilizing the Amazon and equatorial Atlantic with West African dust. Geophysical Research Letters, v. 37, n. 14, 2010.

CHIAPELLO, I. et al. Origins of African dust transported over the northeastern tropical Atlantic. Journal of Geophysical Research: Atmospheres, v. 102, n. D12, p. 13701-13709, 1997.

CHOU, Ming-Dah; ZHAO, Wenzhong. Estimation and model validation of surface solar radiation and cloud radiative forcing using TOGA COARE measurements. Journal of climate, v. 10, n. 4, p. 610-620, 1997.

COX, Charles; MUNK, Walter. Measurement of the roughness of the sea surface from photographs of the sun's glitter. Josa, v. 44, n. 11, p. 838-850, 1954.

DRAXLER, R. R.; ROLPH, G. D. HYSPLIT (HYbrid Single-Particle Lagrangian Integrated Trajectory) model access via NOAA ARL READY website (http://ready. arl. noaa. gov/HYSPLIT. php). NOAA Air Resources Laboratory. Silver Spring, MD, v. $25,2010$.

DUBOVIK, O. et al. Accuracy assessments of aerosol optical properties retrieved from Aerosol Robotic Network (AERONET) Sun and sky radiance measurements. Journal of Geophysical Research: Atmospheres, v. 105, n. D8, p. 9791-9806, 2000. 
DUBOVIK, Oleg et al. Variability of absorption and optical properties of key aerosol types observed in worldwide locations. Journal of the atmospheric sciences, v. 59, n. 3, p. 590-608, 2002.

DUNCAN, Bryan N. et al. Interannual and seasonal variability of biomass burning emissions constrained by satellite observations. Journal of Geophysical Research: Atmospheres, v. 108, n. D2, p. ACH 1-1-ACH 1-22, 2003.

GLÄSER, Gregor et al. The transatlantic dust transport from North Africa to the Americas-Its characteristics and source regions. Journal of Geophysical Research: Atmospheres, v. 120, n. 21, p. 11,231-11,252, 2015.

HAYWOOD, James; BOUCHER, Olivier. Estimates of the direct and indirect radiative forcing due to tropospheric aerosols: A review. Reviews of geophysics, v. 38, n. 4, p. 513-543, 2000.

HOLBEN, Brent $N$. et al. AERONET-A federated instrument network and data archive for aerosol characterization. Remote sensing of environment, v. 66, n. 1, p. 1-16, 1998.

HORVATH, H. Atmospheric light absorption-A review. Atmospheric Environment. Part A. General Topics, v. 27, n. 3, p. 293-317, 1993.

IPCC, Climate Change. The IPCC Scientific Assessment. 1990.

JONES, Charles et al. The role of easterly waves on African desert dust transport. Journal of Climate, v. 16, n. 22, p. 3617-3628, 2003.

KATO, Seiji et al. Surface irradiances consistent with CERES-derived top-of-atmosphere shortwave and longwave irradiances. Journal of Climate, v. 26, n. 9 , p. 2719-2740, 2013.

KAUFMAN, Yoram J.; SENDRA, Claudia. Algorithm for automatic atmospheric corrections to visible and near-IR satellite imagery. International Journal of Remote Sensing, v. 9, n. 8, p. 1357-1381, 1988. 
KAUFMAN, Y. J. et al. Dust transport and deposition observed from the Terra-Moderate Resolution Imaging Spectroradiometer (MODIS) spacecraft over the Atlantic Ocean. Journal of Geophysical Research: Atmospheres, v. 110, n. D10, 2005.

KEDIA, Sumita et al. Radiative impact of a heavy dust storm over India and surrounding oceanic regions. Atmospheric Environment, v. 185, p. 109-120, 2018.

KOREN, Ilan et al. The Bodélé depression: a single spot in the Sahara that provides most of the mineral dust to the Amazon forest. Environmental Research Letters, v. 1, n. 1, p. 014005, 2006.

KRATZ, David P. et al. Validation of the CERES Edition $2 B$ surface-only flux algorithms. Journal of Applied Meteorology and Climatology, v. 49, n. 1, p. 164-180, 2010.

LEVY, R. C. et al. Global evaluation of the Collection 5 MODIS dark-target aerosol products over land. Atmospheric Chemistry and Physics, v. 10, n. 21, p. 10399, 2010.

LEVY, R. C. et al. The Collection 6 MODIS aerosol products over land and ocean. Atmospheric Measurement Techniques, v. 6, n. 11, p. 2989, 2013.

LI, F.; VOGELMANN, A. M.; RAMANATHAN, V. Saharan dust aerosol radiative forcing measured from space. Journal of Climate, v. 17, n. 13, p. 2558-2571, 2004.

Liou, K.N. An Introduction to Atmospheric Radiation. Second Edition, Academic Press, USA, 2002.

LIU, Dong et al. The three-dimensional structure of transatlantic African dust transport: a new perspective from CALIPSO LIDAR measurements. Advances in Meteorology, v. 2012, 2012.

LOHMANN, U.; FEICHTER, J. Global indirect aerosol effects: a review. 2004.

MAYER, Bernhard; KYLLING, Arve. The libRadtran software package for radiative transfer calculations? description and examples of use. 2005. 
MIDDLETON, N. J.; GOUDIE, A. S. Saharan dust: sources and trajectories. Transactions of the Institute of British Geographers, v. 26, n. 2, p. 165-181, 2001.

MILTON, S. F. et al. Modeled and observed atmospheric radiation balance during the West African dry season: Role of mineral dust, biomass burning aerosol, and surface albedo. Journal of Geophysical Research: Atmospheres, v. 113, n. D23, 2008.

MOULIN, C. et al. Satellite climatology of African dust transport in the Mediterranean atmosphere. Journal of Geophysical Research: Atmospheres, v. 103, n. D11, p. 13137-13144, 1998.

MYHRE, Gunnar et al. Radiative forcing of the direct aerosol effect from AeroCom Phase II simulations. Atmospheric Chemistry and Physics, v. 13, n. 4, p. 1853 , 2013.

MYHRE, Gunnar; SHINDELL, Drew; PONGRATZ, Julia. Anthropogenic and natural radiative forcing. 2014.

NASA, Ceres Instruments, c2020. Disponível em: <https://ceres.larc.nasa.gov/instruments/>. Acesso em: abr. de 2020.

OKIN, Gregory S. et al. Impact of desert dust on the biogeochemistry of phosphorus in terrestrial ecosystems. Global Biogeochemical Cycles, v. 18, n. 2, 2004.

OLULEYE, Ayodeji; JIMOH, Olatunji. Influence of atmospheric circulation patterns on dust transport during Harmattan Period in West Africa. Pollution, v. 4, n. 1, p. 9-27, 2018.

OTT, S. T. et al. Analysis of a trans-Atlantic Saharan dust outbreak based on satellite and GATE data. Monthly Weather Review, v. 119, n. 8, p. 1832-1850, 1991.

PROSPERO, Joseph M.; CARLSON, Toby N. Vertical and areal distribution of Saharan dust over the western equatorial North Atlantic Ocean. Journal of Geophysical Research, v. 77, n. 27, p. 5255-5265, 1972. 
RAJEEV, K.; RAMANATHAN, V. Direct observations of clear-sky aerosol radiative forcing from space during the Indian Ocean Experiment. Journal of Geophysical Research: Atmospheres, v. 106, n. D15, p. 17221-17235, 2001.

REBOITA, M. S. et al. Precipitation regimes in South America: a bibliography review. Revista Brasileira de Meteorologia, v. 25, n. 2, p. 185-204, 2010.

REMER, Lorraine A. et al. Global aerosol climatology from the MODIS satellite sensors. Journal of Geophysical Research: Atmospheres, v. 113, n. D14, 2008.

RUTAN, David A. et al. CERES synoptic product: Methodology and validation of surface radiant flux. Journal of Atmospheric and Oceanic Technology, v. 32, n. 6, p. 1121-1143, 2015.

SASSEN, Kenneth et al. Saharan dust storms and indirect aerosol effects on clouds: CRYSTAL-FACE results. Geophysical Research Letters, v. 30, n. 12, 2003.

SATHEESH, S. K.; RAMANATHAN, V. Large differences in tropical aerosol forcing at the top of the atmosphere and Earth's surface. Nature, v. 405, n. 6782, p. 60-63, 2000.

SILVA, Bianca Lobo. Estudo do efeito das partículas de aerossol emitidas por queimadas sobre a radiação solar incidente em superfície a partir de medições efetuadas na Reserva Biológica do Jaru. 2012. Dissertação de mestrado. Universidade de São Paulo.

SINGH, Atinderpal et al. Characterization and radiative impact of dust aerosols over northwestern part of India: a case study during a severe dust storm. Meteorology and Atmospheric Physics, v. 128, n. 6, p. 779-792, 2016.

SMITH, G. L. et al. Clouds and Earth Radiant Energy System (CERES), a review: Past, present and future. Advances in Space Research, v. 48, n. 2, p. 254-263, 2011. 
STAMNES, Knut et al. Numerically stable algorithm for discrete-ordinate-method radiative transfer in multiple scattering and emitting layered media. Applied optics, v. 27, n. 12 , p. 2502-2509, 1988.

SU, W. et al. Next-generation angular distribution models for top-of-atmosphere radiative flux calculation from CERES instruments: Methodology. Meas. Tech, v. 8, n. 2, p. 611-632, 2015.

SWAP, Robert et al. Saharan dust in the Amazon Basin. Tellus B, v. 44, n. 2, p. 133-149, 1992.

TIWARI, Shani et al. Assessment of two intense dust storm characteristics over Indo-Gangetic basin and their radiative impacts: A case study. Atmospheric Research, v. 228, p. 23-40, 2019.

WASHINGTON, Richard; TODD, Martin C. Atmospheric controls on mineral dust emission from the Bodélé Depression, Chad: The role of the low level jet. Geophysical Research Letters, v. 32, n. 17, 2005.

WASHINGTON, Richard et al. Dust and the low-level circulation over the Bodélé Depression, Chad: Observations from BoDEx 2005. Journal of Geophysical Research: Atmospheres, v. 111, n. D3, 2006.

WINKER, D. M. et al. The CALIPSO mission: A global 3D view of aerosols and clouds. Bulletin of the American Meteorological Society, v. 91, n. 9, p. 1211-1230, 2010.

WISCOMBE, Warren J. Improved Mie scattering algorithms. Applied optics, v. 19, n. 9 , p. $1505-1509,1980$.

XIONG, Xiaoxiong; BARNES, William. An overview of MODIS radiometric calibration and characterization. Advances in Atmospheric Sciences, v. 23, n. 1, p. 69-79, 2006.

YAALON, D. H.; GANOR, E. East Mediterranean trajectories of dust-carrying storms from the Sahara and Sinai. Saharan dust, p. 187-193, 1979. 
YAMASOE, M. A.; CORRÊA, M. de P. Processos Radiativos na Atmosfera: Fundamentos. São Paulo: Oficina de Textos, 2016.

ZHANG, Hao; WANG, Menghua. Evaluation of sun glint models using MODIS measurements. Journal of Quantitative Spectroscopy and Radiative Transfer, v. 111, n. 3, p. 492-506, 2010. 